Portland State University

PDXScholar

$1-1-1964$

\title{
Use of the depth interview in examining attitudes of delinquent boys: an exploratory study
}

\author{
Alice Allen \\ Portland State University \\ Jean Altorfer \\ Jerry Brickey \\ Lee Cumpston \\ Suse Katz
}

See next page for additional authors

Follow this and additional works at: https://pdxscholar.library.pdx.edu/open_access_etds Let us know how access to this document benefits you.

\section{Recommended Citation}

Allen, Alice; Altorfer, Jean; Brickey, Jerry; Cumpston, Lee; Katz, Suse; Mitchell, Bertha; Plummer, Bernadette; Powell, Alden; and Selling, Carolyn, "Use of the depth interview in examining attitudes of delinquent boys: an exploratory study" (1964). Dissertations and Theses. Paper 119.

https://doi.org/10.15760/etd.119

This Thesis is brought to you for free and open access. It has been accepted for inclusion in Dissertations and Theses by an authorized administrator of PDXScholar. Please contact us if we can make this document more accessible: pdxscholar@pdx.edu. 


\section{Author}

Alice Allen, Jean Altorfer, Jerry Brickey, Lee Cumpston, Suse Katz, Bertha Mitchell, Bernadette Plummer, Alden Powell, and Carolyn Selling 


\title{
USB OF THE DEPTH INTEREIEW IN EXAMINING ATTITUDES
}

OF DELINQUENT BOPS: AN EXPLORATORY STUDY

\author{
by \\ ALTCE ALISEN \\ JEAN ALTORFER \\ JERRY BRICKEY \\ ISE CUMPSTON \\ SUSE KATZ \\ BERTHA IITTCHELT \\ BERNADETTE PLUMMISR \\ AIDEEN POWELd \\ CAROLIN SELLING
}

A CROUP PROJECT

Presented to the School of Social Work

of Portland State College

In partid sulfillment

of the requirements for the degree of

Master of Social Work

June 1964 


\section{ABSTRACT}

This exploratory study was designed to disclose new diroctions fos further rasaarch and practice in the field of juvenile delinquency.

By exploring through limitsd depth interview the attitudinal areas of authority, fear, aspirations for the future, obstacles to be overcome, capabilities, societal 1deals and therapy the project attempted: (1) to elicit, from adjudged juvenile delinquents, information different from that usualiy sought by public social agencies and (2) to evaluate the depth interview technique as a means of ellciting such material.

Specific criteria were established for choosing fifteen interviewees, selected from three methods of dealing, with juvenile delinquency: probation, institutionalization and parole. Depth interviews were conducted in a laboratory setting with which the respondents were familiarized prior to the interview. Open-end questions allowed latitude for pursuing the boys' spontaneous responses. The degree of observer reliability was based on the use of standardized schedules on which each observer evaluated the responses of each interviewee.

Conclusions which tended to substantiate prior Pindings were that generally these delinquents had a low self concept and had the most difficulty in interpersonal relationships. Although they asw their problems as being internal, they projected theis troubles onto external factors. Noticeably minimal wore identification with parent figures and ability to plan for the future.

Further examination of the discrepancies between the delinquents? frames of reference and those of the elements of society concerned with delinquency, and the current efficacy of social work techniques in treating the problems of delinquency were indicated.

Findings of this study suggest that further research into all seven attitudinal areas would help to clarify the problems and treatmont of juvenile delinquents. 


\section{Acknowlodgenents}

The research group wishes to express its appreciation to the members of the social work community who gave generously of their time and counsel to assist in bringing this project to fruition, and to the boys who cooperated by providing the research data.

To Mr. Jack Frost, Executive Director of the Netropoliten Youth Commission, Mro. Albert Green, Director of the Multnomah County Juvanile Court and Home, Hr. Amos Reed, Superintendent of MacLaren School for Boys and Dr. Gordon Hearn, Director, School of Social Work, Portland State College go special thanks for their advice and suggestions.

A very real debt of gratitude, for his constant support and guidance, is acknowledged to our research advisor, Dr. Frank Miles, Associate Professor of Social Work, Portland State College. 


\section{CIIAPTER}

I. INTRODUCTION

Purpose of the Study............. I Background. .............. 2

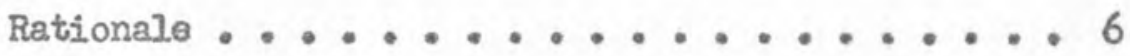

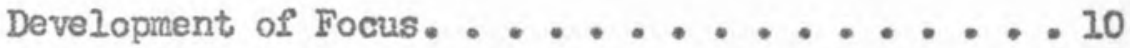
General Approach............ 11

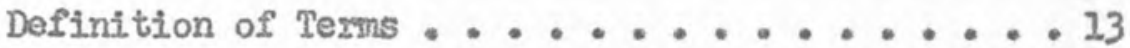

General Overview of the Study ....... 16

II. REVIEW OF THE ITTERATURE

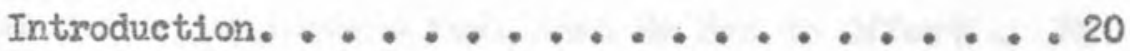

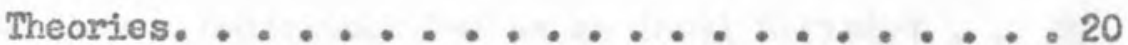

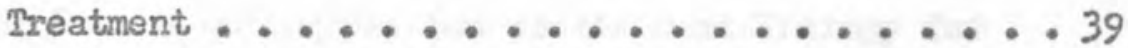

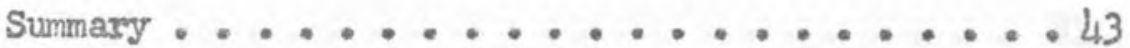

III. METHODOIOGY

Selection of the Areas to be Studiod. ..... 49 Criteria for Selection of Interviewees. .....51

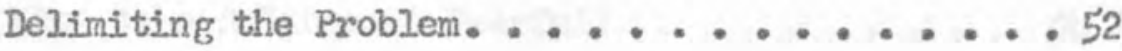
The Preliminary Interview .......... 55

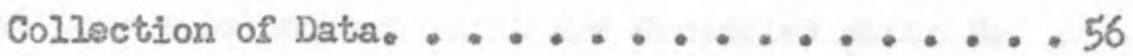
Physical Facilities ........... 57 Preparation of the Interviewees ........ 57 
Iimitations of the Interviov Situation on observes 59 I mitations of the Interview Situation on Observers 60 Selection of Data to be Used......... 60 Marking the Schedules ............61 Complling the Data................ 62 Testing of Hypotheses............. 62

\section{FINDINGS}

What is a Dslinquent's Attitude Toward Authority? . 65 of What is a Delinquent Fearful?........ 74 What are a Delinquent'a Asplrations for the Future? 75 What Doss a Dolinquent Think aro Obstacles Which Ho Needs to Ovarcomo? ......... 77 What Does a Delinquent Fael that He Has to Offer? 78 What Does a Delinquent See as an Ideal Society? . 80 What Does a Delinquent See as the Best Therapy for

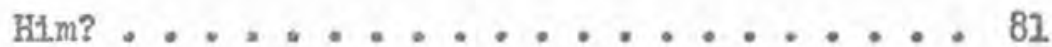

General Renarks ............. 82

V. EVALUATION AND INPIICATION FOR PRACTICE AND FUTURE STUDY What is a Delinquent's Attitude Toward Authority? . 93 of What is a Delinquent Fearful?......... 94 What are a Delinquent's Aspirations for the Iuture? 95 What Does a Delinquent Think are Obstacles Which He Needs to Overcome? ................. 98 
What Does a Delinquent Feel That He Has to offer? 99 What Does a Delinquent See as an Idea]. Society? . 200 What Does a Delinquent See as the Best Therapy for $\mathrm{H} n$. . . . . . . . . . . . . 102 Conclustons ............... 103 Selected Bibliogaphy . . . . . . . . . 106 Appendix A - Interviewer's Schedule . . . . . . 113 Appendix B - Observer's Schedule. . . . . . 115 Appendis C - Testied Hypotheses. . . . . . . II6 Appendix D - Surnary of Tests Used. . . . . . 228 
v1

\section{IJST OF TABIES}

\section{Table}

I Attitudinal Areas Studied and Questions Utilized from the Observer's Schedule. ....67

II Number of Times Observers Saw Each Interviewee Mentioning a Class of Individuals as Controlling Him ........... 68

III Number of Tjmes Observers Saw Each Intexviewee Express Resentment Toward a Class of Individuals by Whom He Felt Controlled. . 70 Responses of Interviewees, as Seen by Observers, Regarding Future Decupational.

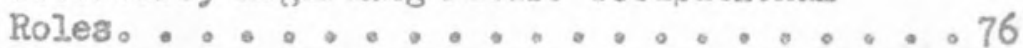


USE OF TIE DEPTH INTERVIEW IN EXAMINING ATTITUDES

OF DELINQUEHIT BOYS: AN EXPLORATORY STUDY

\section{CHAPTER I}

\section{INTRODUCTION}

This is an exploratory study, the purpose of which is two-sold. The first is an attempt to elicit new information from juvenfile dolinquents regarding certain attitudes, oplntons and ideas relating to auch areas as authority, fear, society and therapy which may be useful for future studies relating to juvenile delinquency through the use of the depth interview. A second is to measure the reliabil. ity and feasibility of the depth interview technique in eliciting information from juvenile delinquents. Since the number of subjects In this study is Ifmited and cannot be thought of in terms of the adequacy of random sompling, the research group does not expect to determine any overall attitudes of juvenile delinquents. This research is not directed toward studying the depth intexview as a diagnostic tool nor as a mothod of treatment in individual cases. It is not concerned with the epidemiolopical, demographic or ecological aspects of juvenile delinquency nor with seeking solutions or making recommendations. This study is concermed with searching for information which could be indicative of net ways of handling juveniles, new directions, dimensions and implications for further study, while holding to the canons of reliability. 
Background

Juvenile delfaquency is a probiem of international concern. In the United States, the two main agencies gathering statistlcs are the Federal Bureau of Investigation and the Children's Bureau. However, even the reported data are not wholly reliable because of numerous variables. Block and Flynn list these variables as: (I) lack of unjform reporting and the absence of compulsory regiatration of delin. quent offenses, (2) variations in court practice in classification and handling of delinquency, (3) variations in the comunity regarding refersal of dolinquancy and behavior problem children, (4) institutional differences in rocelving children for care and their methods of reporting and (5) differences in police administration for handling of juvenile offenses brought to their attention. ${ }^{2}$

Neumeyer reported that in $195912.3 \%$ of the total number of arrests were porsons under elghteen years of age. This percentage represented $63.3 \%$ of the total arrests for auto theft, $52.4 \%$ of those for burglary, $48.9 \%$ of those Lor larceny, $30.2 \%$ of those receiving and possessing stolen property and $26.2 \%$ of those for robbery. 2

CssselI reported that in the United States, one out of every five boys had a deinquency record before they were eighteen years of age, with about five times as many boys as girls involved. ${ }^{3}$

In 1956, Kvaraceus predicted that the post World War II wave of population would raach the secondary school by 1960 and increase the enroliment by about $32 \%$ over the 1949.50 enrollment. 4 He also indicated this should result in a comparable increase in the incidence of delinquency, but the increase in delinquency in the past fow years has 
been more than four times the population increase.

Class enumerated six major changes in the juvenile delinquency pattern: (1) today juveniles begin deljnquent activities at an earlier age, (2) there is a shift from predominantly urban to an increasing percentage of rural children, (3) there is a shift from predominantly lower socio-economic groups to an increasing number of middle class children, (4) there is an increasing ratio of girls to the formerly predominantly male delinquency, (5) cultures that had formerly seemed resistant to delinquency-producing forces have begun to succumb, and (6) the chasacter of the offenses have become more violent in recent years. 5

The Children's Bureau reported that except for a slight decrease in 1961, juvenile delinquency has increased steadily since 1940.6

New aims and new, more effective methods of dealing with this problem are being sought. There have been many studies done but in spite of concern and efforts, juvenile delinquency continues to increase. Albert K. Cohen has said,

"Ideally, we should like to see systematic research, probably employing "depth interview" and "projective" techniques, to get at the relationship between status position and aggressive dispositions toward the rules which determine status and toward persons variously distributed in the status hierarchy ${ }^{\text {n }}$ ?

One study reported by Janes Ro MacKay used the depth interview technique in eliciting infornation from boys as to the meaning of their drinking experiences 8 This study showed that because of severe emotional problems, all of these young addictive drinkers drank excessively in opposition to their own personal beliefs and to the rules of the society in which they lived. Each of the boys was interviewed individually by psychiatric social workers who focusad on 
eliciting his opinion as to why he drank, his attitudes toward adulta, toward his peers and his attitudes in general as to why people drink. The study reportad a nead for an integrated public health program, research, education, treatment and prevention.

Another study was done by Francis $R$. Duffy in cooperation with the Allegheny County Juventle Gourt and Allegheny County Probation Department in Pennsylvanis.9 Interviews with fifty girl and fifty boy delinquents in which they expressed an appralsal of their situation and their reaction to 1 t were recorded on tapes.

In a study of "unreached youth" conducted by David J. Kallen the purpose was to conduct an exploratory investigation of access to learnm ing, opportunity structures and delinquent activities, social norms and values and use of leisure time ${ }^{20}$ His method was to use semistructured interviews with forty-five boys, ages fifteen through seventeen。

A current study beinf, conducted at the Institute of Behavioxal Seiences by Sophia $M_{0}$ Robison and Gene Levine employs a depth interview technique. 11 The olan is to interview four hundred or five hundred adult males who are respectable members of society regarding their ow youthful delinquent behavior.

Sheldon and Eleanor Glueck, in a study of forty wour sociocultural factors of a family environment upon delinquency found, among other things, that a boy's attitudes toward authority "concern basic ways in which the individual attempts to establish his place, his security and his share in society and in life。"12 
While some of the aboveanentioned studies used a "depth interview" tochnique and some explored attitudes, none actually defined either. They have, however, added to knowledge of the uses of techniques。

A study particularly pertinent to this exploratory study was one undertaken by Kenneth Polk at the request of the Metropolitan Youth Commission in Portland, Oregon, for use in planning services to delinquent youtho 13 Preliminary findings were: (1) about threefourths of juvenile delinquents are male, (2) ninety per-cent of delinquent males comit their offenses within a group structure, (3) delinquency involving violence is not present to a significant degree, (4) minor offenses such as runaway and truancy account for nearly half of all offenses and (5) while there seoms to be a concentration of delinquency in the lower economic groups, there is little difference in the tyoe of offense in the various economic levels. His study went on to compare delinquency rates in various areas of the metropolitan community.

The chairman of the letropolitan Youth Commission suggested that the School of Social work in Portland could contribute additional data or a viewpoint on juvenile delinquency differens from the findings of the Polk study. The Netropolitan Youth Commission, established in 1961, operates as an advisory and study body interested in youth and juvenile delinquency with a focus on prevention of juvenile delinquency. The School of Social Work agreed to participate in the study program of the Commission by suggesting that graduate students, as one of the group research projects, do a study of juvenile 
delinguency using the depth interview technique.

"Depth interviews with delinquent juveniles as a means of dis. covering dimensions for further study" was chosen by the faculty as one of the group research projects to be undertaken by students at the graduate School of Social Work at Portland State College. Nine students decided to participate in this study. L

The group decided to explore seven attitudinal areas with juven1le delinquent interviowees: authority, fear, aspirations, obstacles or problems to be overcome, telents or capsbilities, societal ideals and therapy.

\section{Rationale}

A social worker's Irame of raference is the psycho-social adjustment of individuals, groups of people or cormunities. This group's frame of reference was limited to the psycho-social adjustment of the juvenile delinquent interviewees. In this study, the group was interested in determining the usefulness of the depth interview technique in eliciting from juvenile delinquents information regarding his psychomsocial problems. This information could be different from that "usually" sought by social agencies. It is expected that intensive or attitudinal dimensions explored by the group will add to the existing extensive information regarding juvenile delinquency and will suggest supplementary programs for more effective prevention and treatment of delinquency.

The remainder of this section will be devoted to a more detailed examination of the rationale behind each of the seven areas selected 
by the group for more intensive study. These areas were anong many suggested by a review of the literature, experience of members of the group and interests of the agencies involved in the project.

Some of the general factors of selection were: promise of new leads, applicability to the sample to be studied, potentiality for objectification or estimation of subjective reactions on the part of obs servers and having the qualities of both theoretical and aoplied values.

1. What is a delinquent's attitude toward authority? This area of exploration was suggested by executives of the Pultnomah County Juvenile Court and the lfetropolitan Youth Commission as a problem area which needed to be explored. The research group, of which seven have had some experience in the field of juvenile delinquency, agreed that this area would be a pertinent area to study inasmuch as attitudes of juvenile delinquents toward authority, as discovered in the study, might lead to new ideas or give a different slant to old ideas. It might throw some light on whether the boys viewed their counselors as positive or negative persons. The group exoected that information elicited from the juvenile delinquent interviewees would give some indication of characteristic attitudes toward authority which will lead to further study.

2. Of what is a delinquent fearful? This question was suggested by a representative of the Hetropoliten Youth Commission. The research group decided that this attitudinal area might be meaningful and significant in a boy's behavior pattern. It was expected that the 
group would find a fear of loneliness and a feeling of rootlessness which might be an important factor in juvenile delinquency. Further research might determine the importance or prevalence of these fears, among others。

3. What are a delinquent's aspirations for the future? This was a question suggested by the superintendent of MacLaren School for Boys. The research group concurred that this would be an interesting, pertinent subject. Exploratory research could lead to information which would show whether the boy's ambitions were adequate, realistic or unrealistic. It was expected that further study in this area, esvecially with regard to possible educative practices in boys ${ }^{g}$ institutions, would be indicatod.

4. What does a delinquent think are obstacles whlch he needs to overcome? This was a question wilch by the consensus of the research Eroup was thought to be important and pertinent. Would a delinquent feel that his "record" was a problem to tve overcome? Would he feel that the problem was to change his behavior? What does the delinquent see as major problen areas? It was expected that exploratory research would yield information which would need further study regarding a delinquent's view of his problem areas。

5. What does a delinquent feel that he has to offer? It was a group decision to explore this area, especially in terms of the deline quent's selfoconcept. What capabilities or talents, if any, does a delinquent think he has? Does he recognize the capabilities he has 
or does he deprecate his abilities? It should be kept in mind here that one of the criteria in selecting the small sample of delinquents to be interviewed was that they be of at least average intellectusl capacity. Results from this preliminary research could lead to further study regarding the relationship of a low self-concept to acting out in delinquent behavior patterns.

\section{What does a delinquent see as an ideal society? The group} decision to explore this area was based on an attempt to inquire into what a boy sees as his ideals as well as inquiring into his relationships with his family, peer groups and adult figures in his environment. Would he want to change his environment if he could? If so, how? Does a delinquent see himsels differently in relation to his world than do others? Does each delinquent have a different concept of the world or do delinquents tend to have similar concepts of the world which might be different from that of nonadelinquents? Further studies might be indicated which would explore whether the delinquent behaves realistically in relation to his concept of his total environe ment as well as exploring whether his concept of the world is realistic.

7. What does a delinquent see as the best therapy for him? This question was suggested by executives of the Metropolitan Youth Come mission and the Ifultnomah County Juvenile Court as an area for investigation. This area is related to that of authority in that responses elicited from the juvenile delinquent interviewee may give information for further study regarding the counselor's role in the 
boy's Iife. Directions for further study as to how counselors might be more effective in their dealings with juvenile delinquents may be indicated.

These seven areas were chosen by a consensus of the group as those which would be the most perifinent, the most interesting, the most significant and the most researchable this group could exolore within its limitations of time, experience and financial resouxces, It vas expected that exploratory research of these areas will point up directions for further study.

\section{Development of Focus}

From the beginning of the project, it was undezstood by the group that this was to be en exploratory study of the depth interview and Its applicability in stuaying attitudes (see definition of attitudes, p.lis) of juvenile delinquents. In order to discover the usefulness of the depth interview, the group decided it would be necessary to study the content of the interview.

The group of nine students discussed areas suggested by the Metropolitan Youth Commission and other proiessionals involved in working with juvenile delinquents, made additions and formulated the seven areas on which the exploratory study was concentrated. Areas such as sex and intimate family inter-relationships were avoided, not because they would not be meaningful areas, but because material might be inappropriately exposed which would necessitate follow up treatment interviews the group was not prepared to provide. Also considered was the fact that the interview could become emotionally charged and 
thus bias the responses.

In discussions of the seven areas, the group concluded that, in order to be able to analyze the effectiveness of the depth interviews It would be necossary for the interviewer to follow a questionnaire so that there would be a basis for comparison for interviews in eliciting responses in each of the seven areas. The decision was reached, also, that in order for the depth interviow to be utilized the questions used must be open-ended.

Each student submftted questions from which a questionnaire was prepared. A schedule for analyzing the boys ' responses was dovised. These will be discussed in more detail in Chapter III.

General Approach

Because of limdtations of time and resources, the group limited Its testing of the depth interview technique to adjudged male delin quests, ages fifteen to seventeen, whose residisnce was in the Portland, Oregon, motropolitan area. The Konneth Polk study, which showed that three out of four referrals to the Juvenile Court were male subjects, was a consideration in limiting the subjects to males, In order to discover differences or similarities in attitudes of juvenile delinquents, the group decided to interview five boys currently on formal probation, five who were institutionalized and five who were on parole from the institution. There were no limitations as to the kinds of offenses the boys had committed nor as to their race or religion. Other criteria for choosing interviewees were that they must have at least average intelligence, be fairly comfortable 
in expressing themselves verbally, be capable of establishing a quick xapport and have a hifh likelthood of sincerity in the interview.

Because of these criteria, the number of subjects interviewed, the selection of traits to be explored and conditions surrounding the conduct of the interview, aims of the study should be kepi in mind. Generalizations not warranted by the findings should not be attributed to any juvenile delinquency population at large.

On the basis of these cxiteria and availability of the boys, five probationers were chosen by personnel of the Multnomah County Juvenile Court, the other ten intervilewes by MacLaren School for Boys. No case history material on the boys was requested nor prom vided by either agency。

The interviews were conducted in a laboratory setiting at the School of Social Work, with use made of a oneway vision mirror and a tape recorder. A preminterview briefing was given to each boy in which he was familiarized with the physical settinga

of the group of nino social work students, one only served as interviewer throughout the series of interviews. The others comm pleted a schedule on which analysis of the Interview and its content would be based. The observers" evaluations of the boys feelings, stititudes and Ideas were derived from what he had verbalized as well as what he had indicated by his posture, facial expression, tone of voice, latency of response and other observable characteristics.

In the depth interviews with the boys there was no attompt made at treatment nox at psychological analysis. It was explained to 
each boy that, so far as this study was concerned, he would retain his anonymity and any personal information which came out in the interview would be considered confidential. In the pre-interview briefing session, he was given information that he would be participating in a project which, hopefully, would contribute nev knowledge about juveniles who get into trouble with the law, the purpose being to know better how to help other youth. A more detajled discussion of the process will be described in Chapter III, Hethodology.

\section{Definition of Terms}

In attempting to axive at an operational definition of "depth interview" the group had difficulty in its search of the literature to find a cloar-cut definition. A research intarview has boen defined by Dr. Phillip Fellin as "a free-to-face verbal interchange, in which one person, the interviewer, attempts to elicit information ox expression of opinion or belief from another person or persons " I I

Robert K. Merton and Patricia I. Kendall say that,

"Depth, as a criterion, involves the elaboration of affece tive responses-odepth of corments may be thought of as varyIng along a continuum. At the lower end of the scale are mere descriptive accounts of reactions which allow little more than a tabulation of positive or negative responses. At the upper end are those reports which set forth varied psychological dimensions of the experience. - symbolisms, anxieties, fears, sentiments as well as cognitive ideas." 15

Raymond Lo Gordon suggests that the "depth of any item of information depends upon its meaning for the respondent, which in turn depends upon his perception of the relationship between the information and the total social context in which it is given。"16 He suggests probing to facilitate association。 
14

For the purposes of this study, it was determined that the definition of a deoth interviow would be "an interview in which the immediate response of the interviewee is subjected to further questioning, or probing, by the interviewer." To illustrate, suppose the interviewer is attempting to elicit information regarding what delinquents fear. The question might be asked, "Can you tell me what you are afraid of?" The joy's response might be, "When I'm doing something wrong, I'm afraid I'll get caughto" The intarviewer would then pursue with, "What do you think will happen to you when you get caught?" The raply might be, "I' 11 have to be punished." The InterViewer might then ask, "Is it punishment of which you are afraid?", to elicit further response from the boy.

The depth interviow as used in this study differs from a casework interview in that there is no diagnosis of the boy"s problein, no assessments of his strengths and weaknesses and no treatment involved, nor does the interview move at the client's pace。

Martin $H$. Neuneyer states that "the term juvenile delinquency defies precise definition " but that "legally it means that a juvenile has violated a national, state or local law that applies only to nonadults or a law that applies to all age groups and is considered a crime if committed by an adult, ${ }^{n} 17$. Richard Perlman says that juvenile delinquency "moans different things to different people "18 "Legally," he goes on to assert, "a juvenile delinquent is one who comits a delinquent act as defined by law and who is adjudicated as such by an appropriate courto" 
Witmer and Kotinsky suggest that "the concept of juvenjile delinquency belongs to a family of blanket concepts which obscure rather than clarify our understanding of human behavior ${ }^{\text {"19 }}$ Sophj.a Robison recognizes the ambiguity of the word delinquency and suggests that "For any study made in this area...(there is)... the necessity of limiting the operational concept to a relatively narrow, but specific, definition." 20

The definition of "juvenile delinquent" as used in this study is "a boy who has been brought to the attention of the Juvenile Court, who has been adjudgad by the court to have cormitted a delinquent act, who has been made a ward of the court and has been either placed on formal probation or committed to hacLaren School for Boys, the state training school for boys in Oregon."

Because the group is studying three classifications of juvenile delinquent boys, it seemed appropriate to include definitions, as used in this study, for clarification and differentiation of these. The first group, formal probationers, are defined as "those boys who, as a result of a delinquent act or acts, have been declared wards of the court and placed under the direct supervision of a Juvenile Court counselor." The second group, institutionalized boys, are "those boys who, as a result of a delinquent act or acts, have been declared wards of the court, are currently under commitment to, and residing at MacLaren School for Boys at Woodburn, Oregon." The third group, parolees, are defined as "those boys who, as a result of a delinquent act or acts, have been declared wards of the court, committed to the care and custody of MacLaren School for Boys, and subsequently have 
been released under the superviston of a field counselor employed by that institution"

By "attitude," based upon Webster's Unabridged Dictionaxy and a dictionary of psychological and psychoanalytical terms, it will be meant, for purposes of this study, as "that which indicates the boy's expressed manner of asting, feeling, thinking or opinion as inferred from his verbalizations, facial expressions, posture, tone of voice, latency of response or other observable si gns ${ }^{n} 21_{9} 22$

Five other operational definitions of words were approved by group discussion. "Control," as used in the rating schedule (see appendix) refers to "control by a person or object with the power to restrain, regulate or puide the behavior of the boyo" "Fear" is a "feeling of anxiety, agitation, dread, uneasiness, constemation or alarmo" "Aspirations" are the "boy's ambitions, desires, hopes or wishes for the future." "Therapy" is a "process whereby the boy can come to understand his problems and be helped to Improve his social adjustment and management of his own conduct." "Ideal society" is "the perfect world as seen subjectively by the interviewees."

\section{General Overview of the Study}

The remaining chapters will report the study substantively。 Chapter II will review the search of the literature pertinent to the seven areas under study. Chapter III will describe the methodology as it developed and was used by the group, including a description of the leboratory setting and its possible influence on the findings. Chapter IV will present the information gleaned from the interviews, 
give an analysis and an interpretation. Chapter V will state the conclusions reached by the group and discuss implications for further study。

This introductory chapter has defined the terms as used in this study, has reviewed the development of focus, has set forth the ration. ale for the study, has given some background and has outlined the purposes of this exploratory research project. 


\section{Reforences}

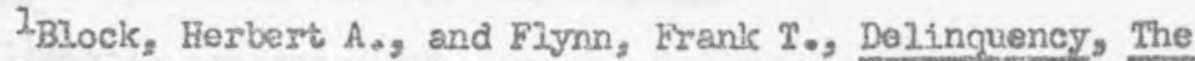
Juvenile Offender in America Today, New York, Random House, 1956, p. 18

${ }^{2}$ Neumeyer, Martin He, Juvenile Delinquency in Modern Society, Princeton, New Jersey, D. Van Nostrand Co., Inc., 1961, p. 35

${ }^{3}$ Cassell, Russe11 N., "The Phoenix Youth Study Proposal for Delinquency Reduction," Journal of Educational Sociology, October, 1959, Vol. 33, No. 2, pp. 67-72

4Kvaraceus, Willian C.s "Forecasting Juvenile Delinquency," Journal of Education, Boston University School of Education, April, 1956, Vol. $138, \mathrm{No} .4, \mathrm{p} .5$

${ }^{\mathrm{C}} \mathrm{lass}$, Norris, "Juvenile Delinqueney Trends and their Implicstions for Social. Action " Paper presented at Portland Chapter of Oregon State Welfare Conference, October 17, 1962, unpublishod

6 Juvenjle Court Statisticsw1961, Washington, D. C., United States Department of Health, Education and Welfare, Children's Bureau, 1962

${ }^{7}$ Cohen, Albert Ko, Deljnquent Boys, The Culture of the Cang, Glencoe, Ilinnois, The Free Press, 1955, po 1.31

8acKay, James R., "Problem Driniking Among Juvenile Delinquents," Crime and Dolinquency, Vol. 9, No. 1, Jamuary, 1963, pp. 29-36

PDrfy, Francis Reg "The Delinquent Child's View of His Problems," "1265, Irom: Current Projects in the Prevention, Control and Treatment of Crime and Delinquency, Barbara Pseschel, (6d.), Hew York, NationaI Council on Crime and Delinquency, Spring, 1962, p. 34,5

10Kallen, David Jo, "A Study of Unreached Youth," \#135, from Current Projects in the Prevention, Control and Treatment of Crime and Delinguency, Barbara Preschel, (ed.), New York, National Council on Crime and Delinquency, Spring, 1962, p. 210

11 Robison, Sophia $M_{0}$ and Levine, Gene, "Career Patterns Project -. a Study of the Youthful Delinquent Behavior of Men Who are Today Respectable Members of Society," $\# 567$, from: Current Projects in the Prevention, Control and Treatment of Crime and Delincuency, Barbara Preschal, (ed.), New Tork, NationaI Council on Crime and Delinquency, Spring, 1963, p. 104

12Gleuck, Sheldon and Kileanor, Family Environment and Delinquency, Boston, Houghton-liffiln Co., 1.962, p. 81 
13Polk, Kemeth, "The Metropoliten Youth Commission Delinquency Study, Preliminary Report," unpublished

14i pllin, Phillip, "The Standardized Interview in Social Work Research," Social Casework, February, 1963, p. 81, as quoted from Eleanor E. Waccoby and Nathan Maccoby, "The Interview: A Tool of Social Science," in Handbook of Social Psychology, Gardner Lindzey (ed.) Roading, Massachusetts, 1954 , Addison-Welsloy Publishing Co., pp. $449-487$

15 Merton, Robert $K_{0}$ and Kendall, Patricia Lo, "The Focused Interview," in Lazarfield, Paul. F', and Rosenberg, Morris, (ed.), The Language of Social Research, Glencoe, Illinois, The Free Press of GLencoe, Inco, 1955, p. 487

16 orden, Raymond Lu, "Dimensions of the Depth Interview," American Journal of Sociology, Vol.62, No.2, September, 1956, p. 258

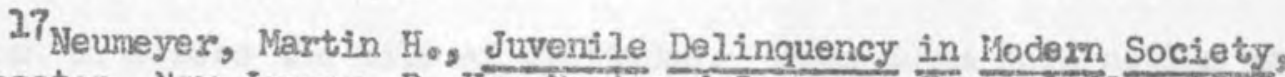
Pxinceton, Nev Jersey, D. Van lostrand Company, Inc., 1961

${ }^{18}$ Perlman, Io Richard, Delinquency Prevention- The Size of the Problem, Washington, Do Cos Vo S. Dopartment of HeaIth, Education and welfare, Social Security Adninistration, Children's Bureau, No. 4,1960, p. 2

$11_{\text {Witmer, Helen L. and Kotinsky, Ruth (ed.) New Persoectives for }}$ Research on Juvenile Delinguency, Washington, D. C., V. S. Departiment of Health, Education and Velrare, Children's Bureau Publication, No. $356,1960, p_{0} 27$

${ }^{20}$ Robison, Sophia Hos Juvenile Delinquency--Its Nature and Control, New York, Holt, Rinehart and Winston, 1960, $p_{0} 13$

21

Webster's New Twentieth Century Dictionary of the English Lane. guege, 2nd Edition, Cleveland and Iew York, World Publishing Co.g 1961, p. 122

${ }^{22}$ English, Horace Bo and English, Ava C., A Comprehensive Dictionary of Psychological and Psychoanalytical Terms, New York, Londong Toronto, Longmerin, Green and $\mathrm{Co}, 1258, \mathrm{p}, 50-51$ 


\section{CHAPTER II}

\section{RISVIEW OF THE LITERATURB}

The purpose of Chapter Two is to provide an overview of significant contributions to the general problem of delinquency, within the scope of the specific areas covered in the study, as delineated in Chapter One.

For the purpose of understanding the relevance of the boys" attitudes to their delinquency it proved advisable to examine some of the theories of delinquency to nrovide a frame of reference within which to assess the role of attitudes. Background information was obtained through a study of social work, psychological and sociological literature of the last five years.

Logical ordering of the material indicated the desirability of dividing the theories to be used into three main categories: environmental, psychological and organic or constitutional. Subsured under these divisions are concepts of delinquency oriented to each specific heading。

The final task of the chapter is to present a sampling of the current thinking regarding treatment-as it affects and is affected by the attitudes studied.

\section{Theories of Delinquency}

In considering the theorles of delinquency, it was decided to refer to the inter-related aspects of these theories and delinquency rather than to treat them as explanations of causes. A definite 
cause and effect relationship has not been conclusively established.

\section{Environmental Thsories}

Enviromental theories include those hypotheses of delinquency which offer the milieu of the child as the primaxy influential factor in his deviant behavior. Within this framework, peer group relationships and community relationships will be examined in the light of attitudes by which they are influenced as well as those they engender.

Peex Group Relationships

The literature on juvenile delinquency suggests that an undero standing of peex group relationships is essential to the understanding of the problem. There is agreement among some theorists that peer acceptance is the prime motivating factor for behavior. ${ }^{1}$ According to Barron, poer groups are often elassified in the same category with family and the neighborhood, and are considered as primaxy groups. ${ }^{2}$

One of the widely accepted theories of delinquency states quite specifically that the concept of cultural conflict is a major determinant of human behavior within a given set of conduct norms ${ }^{3}$ According to this theory, the norms of the immedlate group supercede those of the larger society because of the increassd accessibility, In the smaller group, to the rewards of status and fdentification. Delinquency results, according to Elltott, when there is a clash of eultures of different subogroups 4

Proponents of this theory do not see delinquency as a result of an absence of norms, but as the expression of a particular subweulture, with its own norms, in conflict with the norms of the domsnant group。 
Harold $W$. Polsky noted that a peer social system was a forceful interacting influence, and no matter how influential a staff cilnfeal program was thought to be, the daily social experience of boys and the roles they played in Cottage Six was the dominant force. The position and status of each boy within his living group proved more important than acceptance by professional staff. 5

Polsky's illustration is an example of the theory of differential association, which has as its main concept the ldea that delinquents learn their values and behavior through association with delinquency and isolation from non-delinquent values. It is within such a frame work that critics of instituilonal care for delinquents find their most effective weapons. Starting from the basic premise of constant and exclusive contect, they argue that since delinquents learn delinquent behavior when they are isolated as a group, group Begregation accomplishes little by way of rehabilitation.

The proponents of this school of thought emphasize the positive aspects of returning a delinquent to the commity where, under care. ful supervision, he may learn socially acceptable behavior.

According to Harold Wo Prautz, violent adolescent gang behavior should be viewed in terms of collective behavioral theory, and should be seen as an expressive crowd behavior. Gang violence, he feels, will disappear only when conmunities provide status and opportunities for the underprivileged segment of their population. 6

One emphasis in studying the gang is on the subculture of youth, which is said to provide devices to adolescents for coping with their 
conditjons of life in our society. It provides means for selfotesting, reconnaisance, searching for Ldentity, ego survival and growth and seif astoem。 7

\section{Community Relationships}

The title of Barron's book, The Juvenile in Delinquent Society, implies community responsibility for the welfare of all its members.

"The theory of a delinquent society implies that society plays an incredibly greater role in making the individual jus venile delinquent than the individual freely determines for himself."

Barron also states that much of the problem of juvenile delinquency can be understood within the framework of the ambiguous ago: status of the juvenile in Amarica 9

This point has been dealt with by Sorenson, who listed as one of the stresses affecting youth the discontinuities between age groups and generations. What society expects of one generation is not always the expected pattern of the succeeding generation. The resultant unpredictability creates potential lack of continuity between one mature generation and the next, which he calls a "generation gap." The widely divergent parspectives of different ages at the same time are referred to as "age group gapso"

Generation gaps are especislly pronounced, he said, in this country, where, in spite of cextain general expectations, the lack of precise role definition influences the child-rearing practices to the extent that there is a great tendency either to keep youth "too young" or make them "prematurely" adults。 10

Another factor bearing on the problen of stresses to which 
adolescants are subject is the pace of social change. Today the gouth have relativoly little cortainty in their life situations. The social institutions, technologies and outlook on life are all not only different from ten years ago, but are in a constantly dynamic state. Almost the only certainty for youth today, this view asserts, is that their world will change drastically. 11

The accelerated tempo of current life tends to make both the past and the future increasingly distant from the present. As this haopens, one of the results is the questioning of the usefulness of lmowledge handed down from one generation to the next. Sorenson maintains that the lack of assurance of applicability of knowledge thus transmitted puts youth into the untenable position of being forced, prematurely, to decide between sets of values. 12

One approach to delinquency emphasizes "status deprivation."13 As our society has grown, some segnents of it have acquired material wealth, social prestige or sone other symbols of preferred status. These values and goals have become recognized as "middlo class valueg" and are accepted by the largest proportion of our society. When ado. lescents are frustrated, by circumstances they are powerless to change, in their attempts to realize middle class goals, delinquency frequentily results, 14

"Delinquent subeulture is a reaction to the gap between aspirations and opportunities to realize them." 15 In his study of delinquent subcultures, Spergel's central hypothesis was that delinquent subo cultures develop from the varying nature and extent of opporitunities available to youths of lowermclass neighborhoods by which to achieve culturally induced success goals. 16 
Jackson Toloy, in his review of Cloward and Ohlin's theory. brought out additional factors which he felt were causative agents In juvenile delinquency. In addition to the dffferential access to legitimate and illegitimate opportunities, offered by Cloward and Ohlin as a major cause of delinquency, Toby suggested the factors of inadequate socialization, culture conflict, adolescent rebellion and status frustration. 17

There appears to be a tendency not to differenti.ate between the total environment and that part of the environment to which an individual reacts. An example of such generalization is the state. ment that "delinquents come primarily from broken homes," one of the more widely accepted beliefs.

Before accepting a broad statement of this nature, it is necese sary to differentiate between a physically broken home and a psycho. logically broken one, and the relative effects of each, depending upon the reaction of the children. Extensive examination of this particue lar reason advanced as a cause of delinquency has not supported the hypothesis conclusively, although the evidence suggests some relationo ship between the age of the child when the home is broken, the circunstances surrounding the break and the consequences to the child. Thomas P. Monahan found that the influence of the broken home on delinquency is a composite effect, but one shown to diminish with the increased age of the child, and no critical age is discernible. ${ }_{0} 18$

Another approach stresses the influence of mass media, such as television and comic books. 19 Frederic Wertham described crimes com mitted by children, inspirations for which were, he said, directly 
traceable to comic books.

According to Barron, there are "three reasons why children have turned to comic books: activity, security and theix own fantasies " 20

The recent mobility and premature sophistication of youth are sometimes citad as deteminants of delinquency. Ruth Cavan claims a major factor in delinquency to be that, in eagerness to achieve adult status, adolescents accept artificial symbols of adult life; specifically, the automobile, Ifquor and illicit sex activity ${ }^{2 I}$

The schools, by their insistence on teaching subjects in which children cannot succeed, are held responsible for delinquency o

"Non-achievement danages self-confidence, leads to rejection by teachers and classmates and makes the children vulnerable to neurotic and delinquent behavior. The frustrations that result from low maxks could very easily lead to some form of aggressive behavior."

Bertram Beck brings out an interesting point in his discussion of the "exiled delinquent," He contends

"We cannot forgive him because we cannot forgive ourselves -. oThe criminal, and the delinquent serve a tragic social function as scapegoats for the fancied sins of 'good citizens." Thus, the segregation vithin the family, the segregation within the cormunity and segregation by the correctional processes are compounded and overlaid by the segregation of public wrath."23

The list of environmental factoss which allegedly contsibute to delinquency may seem endless. There are today few proponents of the unit or singular-causation theory of delinquency, with most studonts of this problem subscribing to the idea of a multiplicity of causes.

According to Bloch and Flynn, the causes of delinquency sift down, in the final analysis, to the factors of motivation, environmental opportunity and comrunity attitude ${ }^{24}$ Subsumed under these headings 
are the numerous fectors of human interrelationships which determine behavior.

The emphasis on enviromental factors is at variance with the formulations of English and Pearson, who see the "naughtiness" in children as axising priaaxily from organic and psychological deternin. ants. 25

\section{Psychological Theories}

For the purposes of this chapter "psychological theories" are those explanations of behavior which stress the individual's intellectual and emotional development as interrelated with environmental stimuli. These theories are considered from the standpoint of their Influence on the explanation of jupenile delinquency.

Specifically, this section is concerned with theories pertinining to self-image, attitudes toward fear, authority and future.

\section{Selfoimage}

Roy Sorenson brings out the view that some of the focal problems of youth today are centered around identity, an integrel part of selfo Image, and selfaesteom. Identity he defines as "the creation of an Inner sense of sameness and continuity, a unity of personality felt by the individual and recognized by others." Ego strengths develop, he says, as a result of the "mutual confirmation of individual and community. ${ }^{\text {n26 }}$

This concurs with frik Erikson's discussion of ego-identity as having 1 ts roots in cultural identity. 27 Another' of Erikson's formu Jations is that the process of formation of the ego is a dynamic one, "yet the achievement of ego-identity is fostered by a sense of 
continuity botween past and present and future goals aro implicit in $2 t_{0}{ }^{m 28}$

Spacific mention of identity as an etiological factor in delinquency is made by Sidney Wasserman, who says,

"The neurotic delinquent adolescent has not been able to make a healthy identification with his mother that would permit him to internalize his parents' demands for socially accepted behavior 0 "29

By the very mention of "socially accepted behavior" Wasserman seems to imply a culturally derived phenonenon, thus supporting the abovementioned authors.

More recently, in the hearings on the Juvenile Delinquency Control Act, Rep. John Kyle, from Iowa, declared:

"The most overiooled Sactor is too simple. of a.l the causes of juvenile delinquency behavior, the one which showe up the most frequently is in the consideration of self-respect. Every one wants to be recognized. Everyone wants stature. Everyone wants to be a little better-osomething that is someone else." 30

A common by Ing to Sorenson, adolescents, being inexperienced, ara vuinesable to the feelings and opinions of those in their immediate environment. They have no reseryes of selfmesteen to tide them over humiliating experiences. The self of these youngsters is threatened while it is still ill-defined and in its early stages of development. 31

Further evidence of the saliency of identification is to be found in a study of aggressive behavior, made by Bandura and Walters. Among other findings, the authors listed "limited identification with the fathers" as being influential in the development of aggressive behev10x. 32 
Sorenson anplified the idea of identification being largely responsible for delinquency in his discussion of alienation of adolescents from their parents, the school, all middle class values and the community--jesulting from status deprivation. The separateness thus engendered, he said, is fed by the hostility of adults and adult institutions and compounds the problems of adolescents by still further limiting their encounters with adults necossary for clarification of their identity 33

On the basis of a number of studies of adolescents some tentative conelusions regarding the connection between self-image and social deviancy can be dramo34 All of these studies support the hypothesis that central to juvenile delinquency is a lack of precise thinking on the part of adolescents about their role in socioty. As Barron has Indicated, the ambiguous position of adolescents is further aggravated by the failure of the laxger society to provide the means for elarification of role.35

Feas

The psychological influence of fear was considered by the group to be a major factor in delinquency. One of the puxposes of the research project was to determine whether some pattern would emerge which would establish a relationship between the subjects' attitudes toword and concept of fear and their status as probationers, residents of MecLaren, or paroleas.

Our culture tends to place high velue on an individual's braverys as manifested by his lack of fear. In their desire for status, 
adolescents become adept at disguising or concealing their fears 36

The fact that fear sometimes appears in a manner suggesting just the opposite emotion nakes it more difficult to recognize and, hence, to alleviate. Also, fear sometimes is evidonced by extreme milaness and conformity, by which attitudes the fearful adolescent protects himself from fear of punishment, disapproval or rejection. 37

Findings of Bancura and Walters indicate that the impulses of the aggressive boys tested were more likely to be controlled by fear than by guilt. They were markedly distrustful of and feared and avoided situations in which they might have become emotionally deo pendent on others ${ }_{0} 38$

The importance of fear as an underlying cause of hostility is widely accepted, but there is some difference of opinion as to the causative agents producing the fear. The Rankian explanation dis. eusses fear as the direct outgrowth of the birth trauma experienced by the infanto 39

A later origin of fear is advanced by Karen Horney, who said that an individual develops his "basic anxiety" as a child, when he feel.s "isolated and helpless in a potentially hostile worldo" 40 From this diffused apprehensiveness develops specific fears, as the organism encounters more of the external worldo

In Sullivan's view, anxiety, the instrument by which the selfo dymarism is structured, is "always the fear of disapproval" of the person, hence fear is the foundation on which the pattern of inter. personal relations is builto 42 
31

One of the theories edvanced by Albert Cohen, that delinquency is a symptom of or method of coping with an underlying problem of adjustment, follows the Sullivanian concept. However, in developing his thesis, Cohen draws heavily from Freudian formulations when he says that delinquent behavior is "learned by the child, himself, perhaps through one or more of the familiar mechanisms of adjustment."42 (Defense mechanismas by which the ego defends itself from assault。)

From these sources, all of whom considered fear to be a root of delinquent behavior, the evidence is strong supporting the necessity for a better understanding of this phenomenon and the way it operates in different personalities.

Authority

Sheldon and Eleanor Glueck considered it essential to know about a boy's attitudes toward authority because authority is important for the genesis and establishment of the individual's psychological situation in the community.

"Attitudes toward authority are of special importance since, in our culture, most irdividuals experience society as authority, at first through the medium of the family (the parents), later through society's agencies (school, church and like sceial institutions)。 443

Controls, those devices by which behavior is limited, are importa ant in any social setting, but especially so in child-rearing. Neaningful controls imply the use of authority to enforce them and to define the limits within thich an individual may operate。 
As he grows,

". . the child develops control of his impulses through a variety of psychologtcal and social experiences, soine of which are: (1) the giving up of infantile pleasures to gain love and security; (2) conscious and unconscious identiffca. tion with and imitation of parental figures; (3) incorporestifon of parental and later comminty standards."44

However, one of the first manifestations of emotional growth toward ultimate indopendence, according to Jersild, is the questioning of parental authority or robellion to it. 45

He further suggests that "adolescent youngsters are moving toward independence when they are fres to rajse questions about their parents without rogarding such questioning as disloyalty, or feeling guilty about ito" 46

This is not to be confused with the behavior of a child who has not learned sufficient control of his impulses which, according to Falsberg, may be the result of several important contributing factors:

First, the absence of one parent, or the unsuitability of avail a able models, which seriously hanpars the child's social and emotional development; second, the lack of motional availability of his parents, regardless of their physical presence; and third, the variance between the standards of the child's family or subculture and those of the larger society. In his view, conflict with authority, a result of any one or a combination of the above-mentioned factors, is one of the basic problems of adolescence. 47

The absence of a parent or unsuitability of avajlable models is discussed in Froud's exposition of the Oedipal conflicto 48 Under the 
described circumstances, the young boy has no opportunity for a satisfactory rosolution of the oedipal conflict, and because he cannot internalize his father's controls, his super-go does not develop to the degree required for optimum social adjustment.

The increase in juvenile delinquency in recent yoars is thus partially attributed to the effects of the fathers' being absent from the homes during World War II and the Korean conflict.

A second obstacle a child may have to wrercome, the lack of emotional availability of parents, regardless of physical presence, is substantiated by a. study of A. H. Johnson and S. A. Szurek, suggeste ing that parental inadequacies were at the root of the serious disturbances found in the delinquents examined. 49

A third factor which Falsborg sees as contributing to insuffi. cient leasning of controls is the posalbility that the standards to which the child's family or subculture adhere may be at variance with those of the larger society, in which case the child becomes a social delinquent. 50

It appears that the results of a child's foeling of being a "misfit," not accepted and a part of the out-group, possible results of the discrepancy between sets of values, are all around us. The hostility thus engendered and the lashing out at society, as well as personal withdrawal, are comnon manifestations of the psychic malado justment thus produced. The most available target for such rebellion is authority.

The Ifinoings of Clusck and Glueck indicate that ambivalence toward authority arises from the fact that although adolescents are 
34

eages to achieve achlt status, the prospect of adult responsibilities is often frlghtening to them, setifing up an internal. tug-of-war in the child. 51

A contributing factor to an adolescent's lack of adherence to authority can be found in the mass media available to all, but more Iikely to be used by impressionable young people, as model.8 of desirable attitudes and bohavior.

Wexthan suggests that "the contempt for law and police and the brutality of punishment in comic books is subconsciously translated by children into conflict with authority and they develop a special Indifference to $i t_{0}{ }^{152}$

The socio-cultural aspect of authority is one which mexits consideration. Dr. Ridolf Dreikurs sets forth the idee that when the authoritarian culture becomes democratic the incidence of delinquency sises perceptibly. 53

This, he claims, is because children have not had the experience that would enable them to make major decisions for themselves and have not yet learned that democratile procedures involve a high level of control and a sense of personal responsibility for one's own actions. He cites the democratization of Eusopean hores as an example of authority breakdom causing increased delinquency. 54

While thers may be a correlation between these two phenomena, this does not take into consideration the possible effects of other sociomeultural factors, such as economic conditions, social and physi.. cal mobilitity and education. 
Q.2ueck and Clueck point out that of the forty-four socio-cultural. factors of fanily 21 ie tested, the only one that was diroctly related to ambivalence towasd authority was the affection of mother for the boy. 55

Such findings are in direct support of peychosnalytical thinking which indicates that a child accopts controls originally from a fear of losing parental love, having learned that certain behavior brings the reward of approbation, while other activities engender disapproval. This was phrased succinctly by Rousseau, who said, "To yield to force (authority -wede) is an act of necessity, not of will-ant the most, an act of prudence." 56 When the individual's personsl desires conflict with cultural dicta, the resulting ambivalence presents problens for whoever is thus affectsd.

In explanations advanced for attitudes of dolinquents toward authority, an interesting problen prosents itself, the answer to which is dependent upon the theoretician's frame of reference. Do the vari. ous fectors--lack of mother love, parental rejection, culturs. isoletion, otc.-scause the chird to feel as he doss toward authority, or does his inherent predisposition to contradictory attitudes influenee the development of these afosementioned factors? If helping the child to clarify his own thinking is a desired goal, then the question of etiology requires an answer. If, on the other hand, society is content to deal, as best it can, with deviant attitudes already developed, the argument becomes purely acadomic. A more complete exploration of these alternatives will be discussed later in this chaptsy under "Troatment" 


\section{Future}

Since the impetus for the project came from authorities in the field of delinquency, it was felt that factors deemed important by them mexited investigation, on the strength of their suggestions, a part of the study was designed to shed light on the boys' attitudes toward the future.

In his study of institutionalized delinquent boys Polsky noted, "the boys" attitudes toward human activity and time are related in that there is little connection between daily activity and future goalso $" 57$

Roger Barker found that "one way a child-oor an adult-may respond to repeated failure is by dreaming he is successful." 58 Such fantasy is sometimes a necessary defense for these youngsters whose feelings of unworthiness are almost intolerable.

The same study brought out that the goals of children are posi. tively correlated with a degree of success; after achieving mastery of a particular task, children are more likely to anticipate repeated success。

Anticipated success was discussed as an influential factor in the overall estimation a child has of himself.

"Social acceptibility in an intimate group such as a school class requires a high degree of conformity to group standards in all sorts of public behavior. The first step in achieving auch acceptibility is to set goals in accordance with the rroup standards on 59

In Grossbard's opinion, awareness of the future is one of the ego's most Important mechanisms for dealing with reality. Although 
the delinquent is arrare that there is a future, it is a nebulous coneept to him and not sufficientiy meaningful to influence his behavior. He cannot postpone gratification of irmediate desires in favor of longaterm satisfaction.

"It has long been recognized that the future has little meaning to the delinquent. He seems to lack capacity to Visualize and anticipate experienees in which he will be involved a few weeks or days hence.. ofle cannot oroject himself into the future ${ }^{\text {"1 }} 60$

Grossbard feels that the delinquent's complete absorption with the present and the consequent acting out of impulses is not only one of the hallmarks of a dolinquent, but also one of the main causative factors in deviancy, because of the delinquent's "lack of awareness of the nature of his behavior or the reaction of others toward it." 61

It is, perhaps, significant that there is a paucity of information on this particular subject, suggesting that little empirical research was found to bear out these hypotheses. For whatever reasons this area has been relatively neglected, the information cited above seems to indicate that more shoul.d be known about the attitudes of delinquents toward the future as well as the relationship between these attitudes and delinquency, if any。

\section{Organic Theories}

In this section is included information and discussion of factors within the physical makeup of the individual which are thought to have a bearing on delinquent behavior.

Cohon uses Freudian thinking as a frame of reference when, discussing juvenile delinquency, he attributes it to the "native antisocial-impulses, comnonly called the Id ${ }^{n}{ }^{n 6}$ According to this theory, 
"the Id is alreedy there at birth in all people. It does not becone criminal through experience. It is criminal from the very start and never changes. What is acquired through ex perience is the shell. of inhibition." 63

Cohen does not subscribe to this idea of etiology of delinquency exclusively, but emphasizes the fact that no one explanation can be applied to all delinquency.

One of the earliest constitutional psychologists was Hippocrates, who suggested a temperament typology and a theory of behavior that is very similar to the current theory of the importance of endocrine secretions as behavior determinants. 64

Bullding on the foundation laid by Hippocrates, Kretschmer investigated the relationship between body build and specific kinds of mental disorders 65

Additional work was done in this fleld by William Sheldon, who attempted to identify and describe the major structural components of the human body and apply this information to the area of delinquency 66 Sheldon is emphatic in majntaining that the structure of the body is the primary determinant of behavior; that modifications of bohavior can be made only within the limitations of the biological structure of the organism, itself。

According, to Teeters and Reinomann, many personelity problems of children and adolescents are precipitated by physical handicaps. Compensatory behavior often develops in such a manner that forns of delinquency result. 67

Another theory, that of endocrine glend malfunctioning, is somew times advanced to explain delinquency. The rationale underlying the 
theory is that either hypo- or hyper-glandular secretions affect the emotional and physical state of the organism and are thus influential factors in the individual's behavior.

Under organic factors is included, too, the incontrovertible influence of brain damage on behavior. Inglish and Pearson, in their discussion of delinquency, cite cortain specific injuries and illnesses which frequently result in excessively aggressive- $-1_{0} \theta_{0}$ "naughty" behavior. 68

Further supporting evidence for physiological etiology of delinquency is found in the recognition that diseases, the effects of drugs on behavior and the physiological changes of adolescence are all potential "culprits" in determining, wholly, or in part, the development of delinquent behavior patterns.

\section{Treatment}

If delinquency is recognized as a major social evil, mitigation of the problem can be considered of prire importance. There is much divergence of opinion as to the most effective methods of desling with juvenile delinquents and their problems, only a sampling of which will be explored here.

Prevention, while it is the most universally eccepted approsch, is 2lso one of the most controversial.

The supporters of theories of environmental generation of delinquency advocate modification of external conditions as the most potent attack on the problem. Plans of this nature emphasiza the soctal treatment。 
40

Proponents of Individual treatment can be found among those theorists who espouse the etiological salience of psychological ox constitutional factors. In this Irame of reference, psychothesapy, individual casework or group therapy are three of the recormended procedures.

In his discussion of dynarnic treatment methods, Richard Jarvis get forth some guiding principles which, in his estimation, are the foundations upon which any successîl treatment of delinquency should rest. 69

Regardless of personal orientation, anjone working with delinquents should, in Jarvis' thinking, recognize a few basic truths: (1) human personality cannot live without love, (2) the individual hromen personality urust come to terms with authority, both internal (the superwego) and external (school, parents, etc.), (3) a child must belong to soneone or something. The need for love and diseipline is especially strong, he says, in the period of adolescence.

Since this orientation is essentially psychologicel, treatment proceeds with the focus on the individual, in one of the abovementioned settings. He does not, however, ignore the existence of other forces impinging on the individual, and delineates specific measures to be taken as well as those to be avoided. For example, when a delinquent roturns to his peer group, Jarvis recommends that treatment shift emphesis from intrapsychic to the boy's relationship to his group.

Another recommended treatment for delinquency is to help the 
42.

ehild get rid of whatever unfortunate symptonis he presents and, at the same time, help him to Iind a suitable substitute.70 A note of caution is required here to be sure that whatever substitute behavior the child adopts must be acceptable not only to society, but to the child as well. There is frequently a tomptation, on the part of the tharapist, to gst the child to do what the therapist thinks is right。 71

One important thing to consider in any treatment program is the variety of possible results. All contingencies must eventually boil down to one reality, and it is necessary for the therapist to "mease ure his estimate of the amount of personal damage to the client involved in giving up certain values against the potential social damage" (of retaining tham), 72

An aspect of treatment that is not as commonly taken into cono sideration as those already mentioned is the potentialliy negative effect on the delinquent. According to Bock,

"No matter what the intent of treatment, the of fender views the experience in simple terms of punishment for wrongdoing。 Free-floating guilt arising from longaforgotten deeds or buried wishes becomes attached to the inmediate cixcumstances. Witho out therapeutic intervention, this guilt irduces anxiety which is dispelled by acts of hostility. Society's action, therefore, in bringing the offender to justice, more often than not fixes his concept of himself as segregated and adds psychological fuel to the fire."73

Sorenson, too, offers suggestions for effective ways of dealing with delinquency. Ho proposes that adolescents be offered leisure time activities, not just for fun, but to challenge competence, "the foundaw tion of autonong $0^{n} 74$

Hls suggests further that thoughtful adolescents should be encouraged to understand the meaning and Importance of their particular 
strage in 13fe. He charges adults with the responstbility of providIng adequate role models and a vruer public image for adolesconts, to help them clarify their own thinking 75

More definitely in the direction of a social aporosch is the diso cussion by Peck and Bellsmith. In their final chapter they point out the value of community responsibility as a wole in preventive work with delinquency and they feel "therapeutic activities" in the treato ment of the child and his parents are important. Yet no single agency can assume the full responsibilitty. They state, "Psychotherapeutic services must not bs jockeyed into the position of serving as a stop gap for poorly funetioning or inadequate social services and facili.ties. $n 76$

Kvaraceus states, too, that delinquency is a cormunitywide problem, requiring the concerted elforts of all community social 1nstitutions to effect any positive changes. He feels that all agencies which come into close contact with children should:

"make a systematic effort to (1) identify and refer those children who are vulnerable, prone, or exposed to the developw ment of undesirable behavior; (2) study and diagnose predelinquent and delinquent children's behavior; and (3) vitilize a.13 cormunity resources in an individualized and Egientific treatment program based on prior study of needs o"?7

The plan he suggests includes the use of one or more of the behavior-predicting scajes, of which there are severel-akinnesota PhItif-phasic Personality Inventory, Porteus ilaze Test, Washburne Socialadjustment Inventorry, Glueck Prediction Tables and K D Prone= ness Scale and Check tist.

All of these suggestid trestrient programs have che goal-ato help the indivicual to maximize his social functioning. The proponents of 


\section{3}

public financing of such prograns argue that if, by preventive tech niques, delinquency can be lessened, or avoided, the social benerits that will accrue to all would seem to more-thenocompensate for whatever expenditure of time, effort and money mey be involved.

\section{Summary}

Recognition of the practical orientation of juvenile delinquency as a social and individual "problem" rather than isolated phenomenon, and awareness of the recipracal dependence between social work theory and practice served as guides for the focus of chapter two.

An attempt has been made to discuss some of the pertinent literature relating to the main consideration of this studymattitudes and reactions of delinquents toward themselves, fear, authority and the future.

The theories of delinquency examined were those pertaining to environment, those of psychological orientation and those theories dealing with organic factors。

Because of social work's inherent interest in treatment and the concern of the cooperating agencies, several suggested methods of treatment were included, as an indication of some of the current thinkIng in this area and, possibly, to be of assistance to those who would labor in pursuit of a solution to the problem of delinquency. 
References

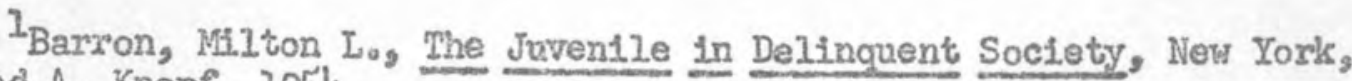
Alfred A。 Knopf, 1954

Cohen, Albert $K_{0}$, Delinquent Boys, The Culture of the Gang, Free Press, Glencoe, Iilinois, 1955, p. 121

Short, et al, "Behavior Dimensions in Gang Delinquency," American Sociological Review, June, 1963

Yablonsky, Lewis, University of California Radio-Television Administration, "The Violent Gang," Broadcast \#6015-U.E.1821, December 9, 1962

2Barron, po 153

BDIjiott, Delbert, "Sociological Contributions to the Theory of Delinquency," an address delivered at the Juvenile Court Institute, University of Oregon, Eugene, Oregon, August, 1963

4 Ibid.

5polsky, Harold Wo, Cottage Six, New York, Russell Sage Founda.m tion, 1962, p. 16 ?

${ }^{6}$ Prautz, Harold, "Group Theory and Collective Behavior: A Critical Reformation," Social Problems, Vol. 9, 1961, pp。 167-174

${ }^{7}$ Sorenson, Roy, "Youth's Need for Challenge and Place in Society," Ghildren, Vol. 9, No. 4, July-Âugust, 1962

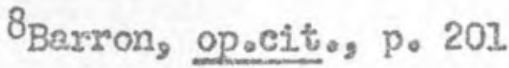

I Tbid., p. 233

${ }^{10}$ Sorenson, loc.cit.

${ }^{11}$ Ibid.

12 Ibid.

$13_{\text {Elliott, loc.cit. }}$

Hroid.

${ }^{15}$ Ibid. 
16 Spergel, Irving, "An Exploratory Research in Delinquent Subcultures," Social Science Review, Vol. 35, No. $1_{g}$ March, 1961, pp. 33-4,

17 Toby, Jackson, "Delinquency and Opportunity," British Journal of Sociology, Vol. 12, No. 3, September, 1961, pp. 282-289, a review of the book by Cloward, Richard $A_{0}$ and Ohlin, Iloyd $E_{0}$, "Delinquency and Opportunity: A Theory of Delinquent Cangs"

18 Monahan, Thomas $\mathrm{P}_{\mathrm{e}}$, "Broken Homes by Age of Delinquent Children," Journal of Social Psychology, Nay, 1960, pp. 387-397

19. Wertham, Frederic, Seduction of the Innocent, New York, Rineheart and $\mathrm{Co}_{0}, 1954, \mathrm{pp}$. I 7 7-193

${ }^{20}$ Barron, op.cit., p. 192

${ }^{21}$ Cavan, Ruth Shonle, Juvenile Delinquency-Development, Treatment, Control, Philadelphia, Hew York, J. B. Lippincott Co., 1962, pp. $97-98$

22Barron, op.cit., p. 177

23 Beck, Bertram, "The Ixilled Delinquent," Children, NovemberDecember, 1955, pe 208

$2 H_{B l o c h}$, Herbert $A_{0}$ and $F_{1} y n n$, Frank T., Delinqueney- The Juvenile Offender in America Today, New York, Randon House, 1.956, p. I7

25English, $\mathrm{O}_{0}$ Spurgeon and Pearson, Gerald H. J., Emotional Problems of IS ving, New York, $W_{0} W_{0}$ Norton and Co., 1963, pp. 300-326

${ }^{26}$ Sorenson, loc.cit.

27 Erikson, Erik Hos Childhood and Society, New York, W. Wo Norton and $\mathrm{Co}_{0}$, Inco, $1950, \mathrm{p}_{0} 239$

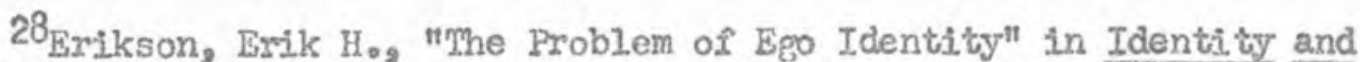
the Iife Gycle (Psychological Issues, Vol. I, No. I, Monograph I), New York, International Universities Press, 1959, po 102, quoted by Neier, Wlizabeth $G_{\circ}$, "An Inquiry into the Concepts of Ego Identity and Identity Diffusion," Social Casework, VoI. 45, No. 2, February, 1964 , p. 63

29 Wasserman, Sidney, "Casework Treatment of the Neurotic Delin. quent Adolescent and the Compulsive Mother," Casework, Vol. 9, November, 1962, p. 489

30 KJle, John, United States Congressional Record, Vol.107, 87th Congress, 1961, po 6319 
${ }^{31}$ Sorenson, Ioc.e1t.

32 Bandura, Albert and Walters, Richard H., Adolescent Aggresslon, A Study of the Influence of Child-Iraining Practices and Family Interrelationships, New York, The RonaId Press Co.g 1959, po 312

${ }^{33}$ Sorenson, loc.cit.

34Duffy, Francis R., "The Delinquent Child's View of His Problems," Current Projects in the Prevention, Control and Treatment of Crime and Delinquency, Spring, 1962, 110.265, p. 345

Juffy, Francis $R_{0}$, and Juxczak, Chester A., "Thirteen Delinquents," Current Projects in the Prevention, Control and Treatment of Crime and Delinquency, Spring, 1962, 110. 313, p. 394

Kallen, David Jo, et al., "A Study of Unreached Youthg" Current Projects in the Prevention, Control and Treatment of Crime and Delinquency, spring, 1962, No. 135, p. 210

Polk, Kenneth, 9t al., "Lane County Youth Study Project," Current Projects in the Prevention, Control and Treatment of Crime and Delinquency, Winter, $1962 \mathrm{~m} 1563$, No. $538, \mathrm{p} .71$

Spergel, op.cit.

35 Barron, op.cite, po 233

36 Jersild, Arthur T., The Psychology of Adolescence, New York, The MacMilizan Co., 1963, p. 205

37 Ibid., p. 206

$38_{\text {Bandura and Walters, op.cit., p. } 32}$

39 Ifunroe, Futh Lo, Schools of Psychoanalytic Thought, New York, Holt, Rinehart and Winston, 1955, p. 576

${ }_{4} \mathrm{OH}_{\mathrm{H}}$ rney, Karen, Oux Innex Conflicts, New York, W. W. Norton and Co., 1945, p. 41

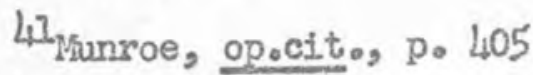

${ }^{42}$ Cohen, Albert Ko, Delinquent Boys, The Culture of the Gang, The Free Press, Glencos, Illinois, 1955, ppo $14-15$

43Glueck, Sheldon and Eleanor, Family Environment and Delinquency, Boston, Houghtonmilifflin Co., 1962, p. BI 
Whalsberg, Martin, "Setting Iitmits wit the Juvenile Delinquent," Social Casework, Vol. 38, No. 3, March, 1957, p. 139

45 Jersild, op.cit., p. 232

${ }^{46}$ Ibid.

47Falsberg, op.cite, po 139

48 Nunroe, op.cit., pp. 202-211

49 Johnson, Adelaide 1\%, and Szurek, S. A., "The Cenesis of Antim social Acting Out In Chilldren and Adults," Psychoanelytic Quarterly, Vol. 21, No. 3, 1952, pp. 323-343

50 Falsberg, op.cit., p. 139

51Giueck, op.cit., po 30

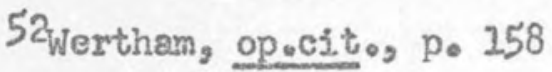

53 Dreikurs, Rudolf, an address delivered at University of Portland, Portland, Oregon, August, 1963

54 Ioid.

55 Glueck, op.cit., po 31

56 Rousseau, Jean Jacques, "The Social Contracts" Great Books, Chicago, London, Toronio, 1952, Vol。 38, po 388

57 Polsky, op.cit., p. 254

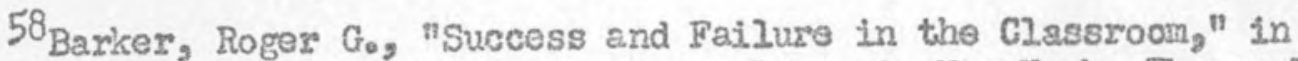
Hainowitz, Morris and Natalie, Human Development, Now York, Thomas $Y_{0}$ Crowe 11 Co., 1960, pp. 543-5447

${ }^{59}$ Ibid., p. 546

${ }^{60}$ Crossbard, Hyman, "Ego Deficiency in Delinquents" Social Casework, Vol. 43, No. 4, April, 1962, p. 172

${ }^{61}$ Ibido, po 177

${ }^{62}$ Cohen, opocit., po Il

63 Ibid.s p. 16

$64 \mathrm{HaJI}$, Calvin So and Iindzey, Gardner, Theories of personality, New York, John Wiley and Sons, Inc., 195?, pp. 338-339 
65 Ibid., p. 340

$66_{\text {Ibid., p. 343-344 }}$

67Teeters, Negley $K_{0}$ and Reinemann, John 0tto, The Challenge of Delinquency, New York, Prentice-Hall, Inc., 1950, p. I01

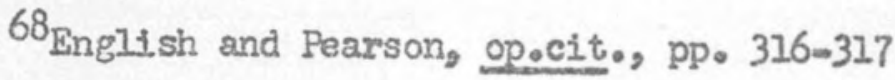

69 Jarvis, Ri.chard, "Dynanic Treatment Methods," an address deItvered at Juvenile Court Institute, University of Oregon, Eugene, oregon, August, 1963

$70_{\text {Ibid. }}$

71 Ibid.

72 Chwast, Jacob, "Value Conflicts in Treating Delinquents," Children, 1959, 6, pp. 95-100

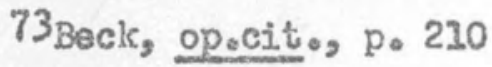

$74_{\text {Sorenson, 20cocito }}$

$75_{\text {Ibid. }}$

76 Peck, Harris Bo and Bellsmith, Virginia, Treatment of the Delinguent Adolescent, New York, Family Service Association of Americe, 1962

77 Kvaraceus, Wm. C., "Forecasting Juvenile Delinquency," Journal of Education, Boston University School of Education, Vol. 138, No. 4, ApriI, 1956, pp. 506 


\section{CHAPTER III}

\section{METHODOLOGY}

As discussed in Chapter I, the problem of studying juvenile delinquents" attitudes through the use of the depth interview grew out of a suggestion of an advisory committee member of the Metropolitan Youth Commission of Portland, Oregon. It was readily evident to the study group that the commission's suggestion that depth interviews of juvenile delinquents, as a means of discovering dimensions for further study, was a broad and encompassing subject. This breadth dictated some specificity and narrowing in order that the problem could be studied in a systematic manner.

\section{Selection of Areas to be Studied}

In the Spring term of the 1963 school year all members of the class who chose to participate in this project met with the faculty advisor of the project and discussion of the problem was undertaken. The advisor outlined the mechanics of the study, polnting out the duties which should be delegated to various members of the group. The group voted one member to act as chairman and another member was elected to work with the chairman. These two comprised the control committee. Two students volunteered to serve on the writing and editing committee. Three additional members of the group chose to be responsible for the statistical area of the study. A treasurer was selected to handle the financial responsibilities such as cost of reproducing and materials. The work charts, minutes of the meetings, 
and work assignment records were delegated to two members chosen by vote of the group.

It was decided by the group that this would be an exploratory study in which attitudes, opinions, and ideas of juvenile delinquents would be elicited through the use of the depth interview tochnique. As there is an indefinite number of subjects about which delinquents would have attitudes, ideas, and opinions, it was necessary to decide upon the specific areas on which the study would concentrate.

All members of the group submitted ideas which were incorporated with the suggestions of the Youth Commission concerning facets of the juvenile delinquency problem which might indicate a need for study。 People actively engaged in dealing with the problem of delinquency were consulted. Items of interest and importance as proposed by these people were also utilized in determining the specific areas to be studied。

The tentative plans for the study were presented by two members comprising the control committee at a meeting of the directors of the Metropolitan Youth Comrassion, Multnomah County Juvenile Court, and MacLaren School for Boys, and the faculty advisor of the project. At this meeting ideas for exploration were discussed. The following questions were framed:

1. What does the delinquent think is the best therapy?

2. What meaning does authority have for the delinquent?

3. How does the delinquent see counseling-an authoritarian or helping process? 
51

4o What fears does the delinquent have?

5. What aspirations for the future does the delinquent have?

Suggestions, ideas, and points of interest which were proposed by nembers of the study group and people actively engaged in dealing with the problem of juvenile delinquency were utilized in the formue lation of the following seven specific areas:

1. The delinquent's attitude toward authority。

2. The delinquent's fears.

3. The delinquent's aspirations for the future.

4. Obstacles the delinquent feels he needs to overcome.

5. What the delinquent feels he has to offer.

6. What the delinquent sees as an ideal society.

7. What the delinquent feels would be the best therapy.

It was agreed upon by the group that fifteen boys would be interviewed with five selected from MacLaren School for Boys, five who were on probation from the juvenile court, and five who were on parole from MecLaren School for Boys. The number of five for each group was an arbitrary decision, keeping in mind the limitations of tjue and resources. Three groups orovided the possibility of analyzing differences and similarities in attitudes as influenced by experiences in these three different situations。

\section{Criteria for Selection of Interviewees}

Because of limitations of time and resources, the group limited its utilization of the depth interview technique in this study to 
adjudged male delinquents. Supporting this decision, the Polk Study showed that three out of four delinquents referred to the juvenile authorities were male. Another limitation placed on the interviewee was that he be fifteen or sixteen years of age, the modal age group of juvenile offenders. Other criteria for selecting interviewees were that they be of average intelligence at least, be fairly comfortable in expressing themselves verbally, and have the ability of establishing a quick rapport. There were no limitations or distinctions made as to the types of offenses committed or to race and religion of the respondents.

It might be pointed out that with the established criteria, the research group did not look for a representative sample of the population of adjudged juvenile delinquents. This was not a study from which generalizations could be made regarding any specific attitude of a larger population. Since the sample was limited, the study did not propose to validate any overall attitudes of juvenile delinquents. The focus of the study was to explore and seek now knowledge regarding the attitudes of the selected population.

It was the hope that any new knowledge elicited would indicate new ways of dealing with delinquency and suggest new directions and Implications for further study.

\section{Delimiting the Problem}

Following agreement upon the specific points around which the study would concentrate, each member of the group submitted a list of 
questions which he thought would elicit responses to these seven areas. These questions were utilized in formulating a guide for the interviewer to use when interviewing the respondents 。

In addition to formulating the questionnaire, two members of the group were assigned the task of devising a schedule on which could be recorded the responses of the interviewees. This schedule was to be constructed in a manner that would allow the observers to record the interviewee's direct responses to questions of the interviewer. Facilities were provided for recording the observers' judgnents as to the intensity of each response. The intensity rating was to be inferred by observable signs such as frequency of mentioning a subject or person, vocal and facial expression, latency of response, and any other factors which the observer might think significant.

In recording the responses on the measurement or rating schedule, the observers were orovided with a ten point scale rating system, This method allowed for a more exact judgment on the part of the observers. Some of the questions were made up of multiple sections. In this type of question the observers ranked the sections in order of importance to the respondent.

This type of schedule was selected for use in this study for the following principal reasons 8

1. A means of recording the interviewees' responses was necessary. 2. The ten point scale system of rating provided the observers with a means of being more specific in their judgnents of the responses。 
54

3. Recorded material on a schedule such as this facilitated transposing into statistical data for analysis.

The design of the study allowed for a considerable amount of data to be collected that could not be analyzed. These data were peripheral or did not necessarily bear on the hypotheses. The group decided upon this course because of the exploratory nature of the study and to provide data for on-going studies and future comparisons. For similar reasons, the interviews were taped and preserved.

In delimitirig the study further, the group concurred that the interviews would not knowingly delve into emotionally sensitive areas of the interviewees. Ihis was decided for three major reasons. First, the authorities from MacLaren School for Boys indicated they did not wish to have the boys from their institution disturbed by the interviews. Second, the study group was in no position to provide follow up treatnent if an interviewoe became emotionally upset as a result of his interview experience. MhIrd, goirg into areas which were indicated as being smotionally sensitive possibly would prevent gaining an uncolored response in succeeding areas.

In addition to meeting the selection criteria, the participants from MacLaren School for Boys were forced to meet other stipulations imposed by institutional authorities. They were to come on certain days and only those who had earned the privilege of home visits were ailowed to participate. 


\section{5}

The Preliminaxy Intervion

With the interviewing questionnaire and evaluating schedule approved, a pre-test was scheduled. The subject of this pre-test was a sixteen-year-old boy on probation from the juvenile court. This boy met the established criteria for all interviewees.

When several people are rating some quality or characteristic, It is imperative that they agree upon what it is they are rating。 Difference in education, personalities, values, as well as the conditions under which their ratings are made, will affect the manner in which the ratings are assigned. However, it is necessary that they all agree semantically regarding the quality or characteristic to be rated if the ratings are to be at all valid, even though they may perceive the quality or characteristic differently. It was one purpose of the pre-test to determine whether the questions and scales on the rating schedule were being interpreted similarly.

Other purposes of the premtest were to ascertain the adequacy of the intorviewing, questionnaire and the rating schedule. This preliminaxy interview was conducted also to provide the group with an insight into how the respondent, observers, and interviewer would react to the interview situation.

Results of the pre-test led to: (1) extensive modification of the schedule, (2) changes in the interviewing process which would allow greater depth to be sought, and (3), discussion of some of the terms used in the schedule in order for the group to reach concensus on their meaning。 
In revising the rating schedule, the nead for the following modifications was indicated:

1. Increase in the dimensions of the schedule to ailow for more extensive coverage of the arsas being studied。

2. Some questions to be rophrased to allow ratings which would coincide with the interviewer's questionnaire.

3. General questions to be more specific and distinct.

4. Some questions to be combined and others repositioned.

5. Add some categories of questions and eliminate others.

With the inadequacies of the procedures pointed out and the necessary changes designated, two member's of the group were assigned the responsibility of incorporating these changes in the schedule.

Members of the group wers given sumer assignments of continued searching of the literature and preliminary writing assignments.

\section{Collection of Dats}

In the fall of 1963, collective work wes resumed by the entire group. Assignments which had been completed during the sumnex were discussed and the revised schedule was approved by the group. A schedule was set up for interviewing the boys who were to participate。

Institutional authorities, who were to assist in selection of the boys were asked to make arrangements with the selected participants and their parents.

A decision was made by the group to have only one person conduct the interviews in order that this factor could be held constant and 
thus reduce the variables which might affect the interviows. Duration of the interviews was reduced from the originally scheduled two hours to approximately one hour. However, the interview would extend beyond one hour if completing the questions demanded. The shorter interview would be paced so as to gain rnore spontaneous responses. It was felt that a longer interview was unnecessarily protracted.

\section{Physical Facilities}

The interviews were conducted in an interviewing laboratory locam ted in the basement of the Portland State College, School of Social Work building. This laboratoxy consisted of two rooms separated by a one-way mirror which allowed the interviewee to be observed without his being able to see the observers. Although the interviewee was apprised of his being observed, it was felt that this situation would reduce the tension which might result from being before an audience. Too, the interviewee might be influenced by visible reactions to his responses by the observers. The laboratory was equipped with microphones and speakers in both rooms, allowing for intercommunication when necessary. In the observation room a machine recorded the interviews for use in further studies and for clarification of any mise understood responses. The equipment provided adequate audio-visual facilities for observers and observees.

\section{Preparation of the Interviewses}

Each interviewee was Samiliaxized with the physical facilities and procedures to be followed. Each boy was introduced to some members 
of the study group upon his arrival at the interviewing laboratory. The tape recorder and microphone system was explained. Any questions which the interviewee posed were answered by the interviewer, who was in charge of the preparation process. All boys were voluntary participants. Each was informed as to the purpose of his being inter. viewed. All participants were assured of retaining their anonymity and any personal information which they divulged would be strictly confidential. The volunteers were promised no reward except the satisfactions they might experience by having contributed to a potentially beneficial scientific project. The boys were permitted to examine the questionnaire which the interviewer would use in talking with them. Any questions they had regarding the questionnaire were answered.

It was the purpose of this preparation and introduction to reduce the anxieties which might result from being in the interview situation. An attempt was made to create a comfortable atmosphere in which the interviewees would feel as free as possible to give replies regarding the seven areas of exploration of the study.

Some difficulty was encountered in assuring the boys' presence at the interview even after careful planning. In one instance the parents had not been previously notified of their son's participation. It was necessaxy for the interviewer, who transported the boys to the inter view, to explain the situation to the parents before they would pernit the boy to leave home. Another boy, enroute to the interview, was cited by police for driving with a suspended license. 


\section{9}

Iintations of Interviow Situation on Observees

The group discussed factors which might have influenced respons ses one way or the other. Among the factors considered were the physical surroundings 。

Factors brought out in the discussion were not considered significant. However, there were such circumstances as the occasional lack of heat and ventilation, difficulty with the equipment, people walking upstairs over the laboratory, and the mirror which allowed the interviewees to see a reflection throughout the interview.

Although the boys' participation in this study was to be voluntary on their part, it must not be overlooked that they came through official channelso-through the court, probation officer, and counselor. As a result of this process some of the boys may have felt obligated to participate. Thus their responses may have been influe enced in such areas 8.8 their attitude toward authority。

Particioation by boys from MacLaren School for Boys became a status symbol for those boys chosen and, too, it gave these boys the opportunity of being away from the institution for half a day。 The other boys received little reward except for gratitude shown for theix participation.

Being aware that they were observed, even though the observers could not be seen, undoubtedly had an effect on the interviewees. Too, knowing that the observing group contained some women might have had a tendency to restrict the replies in some areas such as sex or other areas which a boy of this age does not cutomarily discuss in the preso ence of women。 
Ismitations of Interview Situation on Observers

The group discussed several factors which may have influenced their ratings of the interviewees' responses. The uncomfortable seating, the acoustics of the observation roorn, and people walking upstairs above the laboratory are factors considered. The equipe ment did not allow for adjustments which would compensate for the difference in the loudness of the voice of the interviewer and inter. viewee. In order to hear the interviewee, at times it was necessary to turn the volume quite high and thus the interviewer's voice would "boom" into the observation room。

\section{Selection of Data to be Used}

It was evident that the amount of data collected could not be utilized in its entirety in this project. Therefore, it was necessasy to decide what data would be used. Through group discussion it was agreed that the data chosen should be that which related closely to the purposes as established in the beginning of the study.

Each member of the observing group, using one of the evaluating schedules, marked each question on the schedule according to his evaluation of its pertinence to the subject. This was done by marking "H" which designated high pertinence or importance, "IS" designating medium, " $L$ " designating low, and " 0 " indicating no importance. The questions rated with "H" and "M" were chosen to be used in analysis of the data. 
Marking the Schedules

Imnediately after completion of the interview each member of the observing group marked the rating schedule. This marking was to be done independently wi.thout discussion among the observers. If there were any questions regarding responses in the interview, the observers were permitted to re-run the tapes on which the interview was recorded。

These controls were not strictly adhered to. Some discussion took place, but it was limited. Also, all schedules were not marked immediately upon conclusion of the interview due to, in the case of the boys from Maclaren, one of the observers' having to return the boys to the institution. In this instance the schedule was marked upon the observer's arrival home.

In reference to the observer who transported the boys from MacLaren, another control problem resulted. In most cases an interview followed the Maciaren respondent and thus the observer missed this interview. Karking the schedule for this missed interview was done on the basis of listening to the tape of the interview.

Another break-down in the control were two instances when pages were missing from the marking schedule of two observers, and were not noticed until the data were being compiled. In each case the observers listened to the tapes to gain the information needed to complete these pages of the schedule.

Inspection of the data revealed that the lack of adherence to the controls in marking the schedules had little or no effect upon the ratings 。 
Compiling the Data

Upon completion of the fifteen interviews the rating schedules were grouped into three categories: (1) parolees, (2) probationers, (3) MacLaren School for Boys, The observers were listed alphabetically and were given a code letter, according to where their name was locatad in the list. For instance a code of "PA 2 A" would mean that the schedule was for the number two parolee and was marked by observer "A"。

Tables wers designed to record the data and all members worked in pairs in transposing the data from the schedules to the data sheets in order to check accuracy。

\section{Testing of Hypotheses}

The aims of the project were approached through the use of null hypotheses in the two najor areas of: (a) observer reliability and (b) the traits attributed to the boys within the seven areas explored。 The null hypotheses were the research hypotheses in as much as reliability could plausibly be exnected in a group of similarly trained observers in a constant situation and because similarity of traits was expected among the groups of boys. This device, of course, allows quantitative estimates of the significance of similarities and dissimilarities in the observers, as well as in the groups of boys.

The group took as sub-hypotheses the null hypotheses of no difference among the observers and no difference among the groupings of boys with respact to each of the seven categories tested. These 


\section{3}

subehypotheses referred to specific questions relating to each of the seven categories of the study.

The statistical tests used to test the hypotheses were principally the Chi Square and Student's t test. A number of other tests were used as checks, such as: 2 , phi coefficient and analysis of variance.

Chi Square was utilized when possible to take advantage of as much of the distribution as could be used. But vhere a test of means seemed sufficient, or there its precision seemed superior, a Student's t test was used.

In conceiving the research design and in analyzing the data it was clear that the underlying concept was one of interaction. What was attxibuted as a characteristic of the boys, for instance, was an inference of observers with common but varying backgrounds irfluenced by the interview, the interviewer, the schedule, the research routines, and other factors.

The boys in turn exhibited reactions influenced by the interview situation, not only by their usual patterns of behavior.

Analysis in terms of individual observers, observers as a group, categories of boys, and boys as a group was an attempt to separate or differentiate as a first approximation, at least, these highly interacting factors.

The entire study group participated in computation of the statism tics under the direction of the statistics chairman. The tests, which were utilized, were discussed in a group session in order for agreement 
64

to be reached as to which tests would be used. Upon completion of the statistical computations, the findings were discussed and two members were chosen to write the chapter dealing with the statistical analysis of the findings.

With the first four chapters completed the group reviewed the project and, with the findings of the study in mind, contributed ideas which seemed to indicate areas for further study. These ideas and implications are collated and discussed further in Chapter V. 


\section{GHAPIER IV}

\section{FINDTNGS}

This chapter is concerned wi.th the results of the ansilyses of the data recorded on the observers' schedules as explained in Chapter III. The observers' schedule was scored by eight observers for each of Sifteen interviews. ${ }^{2}$ The results scored on the schedule were then tabulated accoroing to observer and interviewee and various statistical tests were perforned.

This chapter presents the findjngs regaxding observer reliability and differences between the three groups of boys--probationers, MacLaren boys, and parcolees- in the seven attitudinal areas studied. The results are presented in a general form under the headings of the seven areas explored. Hypotheses and statistical tests used will be found in the Appendix, begining at page 116 .

The null hyoothesis that there was no significant difference among the observers was not rejected for all seven areas of study. The null hypothesis that there was no sigmificant difference among the three groups also was not rejected, with certain exceptions which will be noted.

The findings of this study are based on both parametric and nonparametric statistical tests of data derived from the observers' schedule. The observers' schedule was constructed in such a manner that cortain traits were placed on a ten point continuum. The observations were taken as the universe to be explored. Two tailed tests were used throughout the study. 
Some traits were noted by observer write-in and did not lend themselves to statistical analysis. These results will be presented in tabular form.

The main hypotheses to be analyzed are:

1. There is no significant difference in judgment among the observers regarding the proportion or degree of response on the schedule to traits of: (1) authority; (2) fear;

(3) aspirations for the future; (4) what delinquents feel they have to overcome; (5) what they feel they have to offer; (6) what they see as an ideal society; (7) their ideas for the best therapy for delinquents.

2. There are no significant differences among the throe groups--probationers, MacLaren boys, and parolees-with respect to their attitudes in the areas of: (1) authority; (2) fear; (3) aspirations for the future; (4) what they feel they have to overcome; (5) what they feel they have to offer; (6) what they see as an ideal society; (7) their ideas for the best therapy for delinquents.

In addition, comparison by statistical methods was made to test whether observers responded in a meaningful, consistent manner to the catepories that had been subsumed a priori under each question.

In tabulating the results of the observers' responses already selected as valid, it was noted that in regard to certain traits there was a low frequency of observer response. Unless there was an initial response by at least eighty-five per cent of the observers, no further 


\section{7}

test of reliability was made. This level has been suggested in the literature and seemed a plausible balance in consideration of Iype I and Type II exrors. 2

Table I shows attitudinal areas studied as well as the questions within each area that were selected for analysis.

\section{TABLE I}

Attitudinal Areas Studied and Questions

Utilized from the Observers' Schedule

\begin{tabular}{l|l}
\hline \multicolumn{1}{|c|}{ Attitudinal Areas } & Questions Used \\
\hline $\begin{array}{l}\text { 2. Delinquents' attitudes } \\
\text { toward authority }\end{array}$ & $3,6,8,10$ \\
\hline $\begin{array}{l}\text { 2. Of what are delinquents } \\
\text { fearful? }\end{array}$ & $16,18,19$ \\
\hline $\begin{array}{l}\text { 3. What are their aspire- } \\
\text { tions for the future? }\end{array}$ & $21,21 \mathrm{~A}, 25$ \\
\hline $\begin{array}{l}\text { 40 What do delfnquents feel } \\
\text { they have to overcome? }\end{array}$ & 33,35 \\
\hline $\begin{array}{l}\text { 5. What do delinquents feel } \\
\text { they have to offer? }\end{array}$ & $42,43 \mathrm{~A}, 44,45$ \\
\hline $\begin{array}{l}\text { 6. What do delinquents see } \\
\text { as an ideal society? }\end{array}$ & 47 \\
\hline 7. What do delinquents think \\
is the best therapy?
\end{tabular}


What is a Delinquent's Attitude Toward Authority?

In the area of authority the first question selected for consideration was, "by whom does the interviewee feel controlled, i॰e,, by a specific individual, a class of individuals, ${ }^{3}$ the world in general, or his own emotions."

TABLE II

Number of Times Observers Saw Each Interviewee

Mentioning a Class of Individuals as Controlling Him

\begin{tabular}{|c|c|c|c|c|c|c|c|c|}
\hline & Probation & & & MacLaren & & & Parole & \\
\hline Boy & Control & $\begin{array}{l}\text { Times } \\
\text { Scored }\end{array}$ & Boy & Control & $\begin{array}{l}\text { Times } \\
\text { Scored }\end{array}$ & Boy & Control & $\begin{array}{l}\text { Times } \\
\text { Scored }\end{array}$ \\
\hline 1 & $\begin{array}{l}\text { Teachers } \\
\text { Adults }\end{array}$ & $\begin{array}{l}4 \\
3\end{array}$ & 6 & $\begin{array}{l}\text { Peers } \\
\text { Cottage } \\
\text { parents }\end{array}$ & $\begin{array}{l}1 \\
1\end{array}$ & 11 & $\begin{array}{l}\text { Adults } \\
\text { Peers } \\
\text { Police }\end{array}$ & $\begin{array}{l}2 \\
4 \\
2\end{array}$ \\
\hline 2 & Peers & 1 & 7 & $\begin{array}{l}\text { Adults } \\
\text { Peers } \\
\text { Cottage } \\
\text { parents }\end{array}$ & $\begin{array}{l}5 \\
1 \\
1\end{array}$ & 12 & $\begin{array}{l}\text { Adults } \\
\text { Police }\end{array}$ & $\begin{array}{l}3 \\
5\end{array}$ \\
\hline 3 & $\begin{array}{l}\text { Adults } \\
\text { Police } \\
\text { Teacher }\end{array}$ & $\begin{array}{l}2 \\
6 \\
1\end{array}$ & 8 & $\begin{array}{l}\text { Peers } \\
\text { Teachers } \\
\text { Staff } \\
\text { Adults }\end{array}$ & $\begin{array}{l}4 \\
1 \\
2 \\
1\end{array}$ & 13 & $\begin{array}{l}\text { Adults } \\
\text { Police } \\
\text { Peers }\end{array}$ & $\begin{array}{l}2 \\
5 \\
1\end{array}$ \\
\hline 4 & $\begin{array}{l}\text { Adults } \\
\text { Peers } \\
\text { Teachers }\end{array}$ & $\begin{array}{l}1 \\
1 \\
1\end{array}$ & 9 & $\begin{array}{l}\text { Counselor } \\
\text { Police }\end{array}$ & $\begin{array}{l}2 \\
2\end{array}$ & $\nu_{4}$ & $\begin{array}{l}\text { Police } \\
\text { Parents }\end{array}$ & $\begin{array}{l}3 \\
1\end{array}$ \\
\hline 5 & $\begin{array}{l}\text { Adults } \\
\text { Teacher } \\
\text { Judge } \\
\text { Counselor } \\
\text { Police }\end{array}$ & $\begin{array}{l}3 \\
1 \\
1 \\
1 \\
1\end{array}$ & 10 & $\begin{array}{l}\text { Peers } \\
\text { Police }\end{array}$ & $\begin{array}{l}3 \\
1\end{array}$ & 15 & $\begin{array}{l}\text { Adults } \\
\text { Peers } \\
\text { Police }\end{array}$ & $\begin{array}{l}1 \\
4 \\
2\end{array}$ \\
\hline
\end{tabular}


Table II indicates those persons by whom the observers saw the boys as feeling controlled. It is most noticeable that those persons who night be considered to have a social work role were rarely mentioned. Authority figures were mentioned relatively frequently. It can be seen that the parolees mention the police more frequently than the other two groups. This table should be viewed in relation to whom the boys saw as most helpful to them as discussed later in this chapter even though the implfcation of control during the interview was in a negative sense.

It was found upon tabulation of the results of the observers' schedules that only the area concerning "feeling controlled by own emotions" was selected by the observers above eighty-five per cent of the tfme. Therefore, a test of reliability was used on this trait. Reliability was satisfactory at the .05 level for observers as a group though the most extreme observer was shown to be beyond the .05 limits. 4

A chi-square test was used to examine differences between the three categories of boys, namely; probationers, MacLaren boys, and parolees. This was to demonstrate how the boys felt they were controlled by their own emotions. Where the observers rated the trait as high or medium regardless of numerical score the item was considered important to the observer and also when a numerical score above seven was recorded by the observer as "liwo" The result of the test showed there was no statisticalizy significant difference among the groups.

A chi-square test was used to determine whether observers' ratings on the sample as a whole showed statistically stgnificant 
differences between the traits. The boys were seen as feeling more controlled by their own emotions and by a class of individuals than by the world in general or a specific individual.

By inspection there appeared to be differences among the three groups of boys in regard to feeling controlled by a class of individuals. However, a chi-square used to test this difference was not statistically significant。

Question Six was concerned with whether the intervievee showed resentment in regard to a specific individual, a class of individuals, or the world in general. An eighty-five per cent or better response by oiververs occurred only in relation to "a class of individualso"

\section{TABLE IIT}

Number of Times Observers Saw Each Interviewee Express Resentment Toward a Class of Individuals by Whom He Felt Controlled

\begin{tabular}{l|l|l|l|l|l||l|l|l|}
\hline \multicolumn{3}{c}{ Probation } & \multicolumn{5}{c}{ MacLaren } \\
Boy & $\begin{array}{l}\text { Person } \\
\text { Resented }\end{array}$ & $\begin{array}{l}\text { Times } \\
\text { Scored }\end{array}$ & Boy & $\begin{array}{l}\text { Person } \\
\text { Resented }\end{array}$ & $\begin{array}{l}\text { Times } \\
\text { Scored }\end{array}$ & $\begin{array}{l}\text { Boy } \\
\text { Person } \\
\text { Resented }\end{array}$ & $\begin{array}{l}\text { Times } \\
\text { Scored }\end{array}$ \\
\hline 1 & Teacher & 3 & 6 & Peers & 7 & 11 & Adults & 6 \\
\hline 2 & $\begin{array}{l}\text { Peers } \\
\text { People }\end{array}$ & 3 & 7 & Counselors & 2 & 12 & Police & 4 \\
\hline 3 & Police & 6 & 8 & Peers & 6 & 13 & Adults & 5 \\
\hline 4 & Peers & 6 & 9 & Peers & 6 & U4 & Police & 2 \\
\hline 5 & Peers & 6 & 10 & Peers & 7 & 15 & Adults & 4 \\
\hline
\end{tabular}


Table III shows that the MacLaren boys expressed resentment toward their peers more often than did either the probationers or parole interviewees. The boys were seen as showing more resentment toward a "class of individuals" than toward "a specific individual" or "the world in general." By observation it appeared as though there might be a difference between the groups of boys regarding their resentment toward the "world in general." However, a non-significant chi-square score was obtained.

In the observer schechle, Question Eight consisted of several subdtvisions. The observers selected for possible testing the scales of acceptance versus resentment, fair versus unfair, and conformity versus continuance of prohibited activity in regerd to the following types of punishment: (a) physical or corporal; (b) scolding; (c) being detained; (d) withholding money or goods 3 (e) withholding privileges.

In regard to acceptance versus resentment, it was found that there was eighty-five per cent or more observer response on physical os corporal punishment and on being detained. The responses to these traits were analyzed for observer reliability. Two statistical tests ( $z$ and $t$ ) were calculated ${ }_{0}^{5}$ Observer reliability was satisfactory at the .05 confidence level. The most deviant observer was found to be significantly different from the group. By inspection it was evident that there were not sufficient differences between the groups of boys for statistical enalysis. 
A chicsquare was used to test the attikudes of acceptance versus rejection of types of punishment. The group of boys as a whole rem sented "physical or corporol purishnent" most often; then "being detained," "withholding privileges," "scolding," and "withholding money or goods" were less important, in that order. A possible difference between groups regarding "withholding money or material goods" and "withholding privileges" was tested by chi-square and showed no significant differences among the groups.

Analysis of the boys" attitudes of "fair versus unfair" to various types of punishmont, showed that the observers responded to "physical or corporal punishnent" and "being detained" more than eighty - five per cent of the time.

A t test of observers" responses to the "fairness versus unfair ness" of being detained, indicated that there was more observer rellability in regard to this type of punishment than to attitudes toward corporal punishment.

Differences anong the groups were not significant by inspection for a determination of the "fajrness or unfairness" of any type of punishment. A chi-square test showed that the group was most cono cerned about the "Sairness versus unfaimess" of physical or corporal punishment。 "Being detained," "scolding," "withholding privileges," and "withholding money or material goods," were important to them in that order.

In regard to the "conformity versus continuance of prohibited activity" seale, a chi-square test showed that there was a significant 
difference among the traits in the entire group of boys, regarding this reaction toward the above-mentioned types of punishment. The types of punishment most likely to lead to continuance of prohibited behavior were "corporal or physical punishment" and "being detained。" Next in importance were "scolding," "withholding privileges," and last, "withholding money or material goods。"

Also tested in regard to attitudes toward authority was the question of how closely Identified with friends (peers) the interviewee seemod. It should be noted that there was a one-hundred per cent response by observers on this question. A $\mathrm{z}$ test on the observer reliability was used and a significant difference was found between mean deviation of the observers from the grand mean. This indicsies lack of observer reliabilitin. A chi-square test among the thrse groups of boys led to accoptance of the null hypothesis.

Further analysis was made of the differences between the parolee and probationer scores only. The scores wero trichotomized into the following categories-1-1-3.9, 4-6.9, 7-10waccording to the ten point scale used in the observer's' schedule with isolate boing scored near zero and close identification near ten. A chi-square test revealed a significant difference between these two groups with the probationers seen as significantly more closely identified with their peers. This particular test illustrates the advisability of hendling the findings by finer statistical methods than were generally used in this study. Cursory analyois did not reveal this difference. However, since there was low obsezver reliabjlity, these differences may have been due to chance. 
of What is a Delinquent Fearful?

The questions tested in regard to fear were Questions Sixteen, Eighteen, and Nineteen. In Question Sixteen, all responses were observed to be less than the required eighty-five per cent. Therefore, no further test of observer reliability was used. However, a chisquare test of those observers who did respond showed a significant difference among what the observers saw as the boys' most frightening experience. This question was further analyzed by combining traits into the following categories: (a) Interpersonal Relationships;

(b) The Inanimate World; (c) Feelings About Self。

A chi-square test revealed significant differences between these categories. The boys were observed to feel more fearful of interpersonal relationships than any other factor. A test for the differences among the groups of boys was significant only in rogard to their fears about natural phenomena or events. The probationers were significantly higher than the other two groups. However, the number of observations was small in all three groups of boys.

Under the area of fears, the question of how important the interviewee thought possossion of money was, was considered. Typologically monøy anxieties were treated under "fear" because there was no better category in the schecule under which to consider then. A z test of observer reliability was used. Here again, the average of the devi-ations did not vary significantly. A chi-square among the groups of boys revealed no signjficant difference. 
Further considered was the extent to which observers saw interviewees express concern about loneliness. Again, a z test was used to examine observer reliability. The null hypothesis was not rejected. A chi-square showed that there was not any significant difference among the categories of boys regarding "commonness of loneliness."

What are a Delinquent's Aspirations for the Future?

In order to detemine attitudes regarding the interviewees' aspirations for the future, the observers rated the interviewees as seeing themselves in later years in terms of the following personality traits: happy, rich, successfol, loved, loving, aggressive, attractive, intelligent, and belligerent, and their opposites. When these traits were compared by chi-square, there was no signjficant difference between the observations noted for the boys. The test showed no pata tern among the boys as a whole as to their future personality traits, as listed on Question 21 on the observer's schedule. However, noted above eighty-five per cent of the time were the traits rich, successful, and intelligent. T tests used to test observer reliability between the "rich versus poor," and "intelligent versus dull" scales showed no significant differences. A z test showed satisfactory obe server reliability on the "guccessful versus unsuccessful" scale。 However, the most extreme observer differed significantly from the group。

A question as to future roles with which the observers rated the boys as having concern was in regard to occupation, family, future 
school, and military service roles. A chiosquare test confirmed that there was a significant difference between the rating of the types of roles seen by the observers. The occupational roles were chosen most often, then future school, and then family roles. Military roles were chosen least. There were no statistically significant differences between the groups of boys. In regard to occupational roles, Table IV shows the variety of responses and the number of observers rating the response。

TABLE IV

Responses of Interviewees, as Seen by Observers, Regarding Iruture Occupational Roles

\begin{tabular}{|c|c|c|c|c|c|c|c|c|}
\hline & Probation & & & MacLaren & & & Parole & \\
\hline Boy! & Aspiration & $\begin{array}{l}\text { Times } \\
\text { Scored }\end{array}$ & Boy & Aspiration & $\begin{array}{l}\text { Tines } \\
\text { Scored }\end{array}$ & Boy & Aspiration & $\begin{array}{l}\text { Times } \\
\text { Scored }\end{array}$ \\
\hline 1 & $\begin{array}{l}\text { Psycholo- } \\
\text { gist }\end{array}$ & 3 & 6 & Teacher & 6 & 21 & Mechanic & 8 \\
\hline 2 & C.P.A. & 4 & 7 & Barber & 6 & 12 & $\begin{array}{l}\text { Veterin- } \\
\text { arian }\end{array}$ & 8 \\
\hline 3 & $\begin{array}{l}\text { Aeronauti- } \\
\text { cal Engin- } \\
\text { eer }\end{array}$ & 7 & 8 & $\begin{array}{l}\text { Jiectrono } \\
\text { ics }\end{array}$ & 2 & 23 & $\begin{array}{l}\text { Gym } \\
\text { Teacher }\end{array}$ & 5 \\
\hline 4 & Architect & 7 & 9 & Barber & 5 & 14 & Mechanic & 7 \\
\hline 5 & $\begin{array}{l}\text { Race Car } \\
\text { Driver }\end{array}$ & 5 & 10 & Nechanic & 8 & 15 & Pilot & 7 \\
\hline
\end{tabular}


It can be seen in Table IV that the probationers saw thenselves in future occupational roles which would require a higher degree of training and skill. Conversely, MacLaren and parole interviewees chose those occupations which required less preparation and formal education. Ilowever, the reader is reminded that the number involved is small.

The observation of the interviewees' ideas of future roles showing Identification with parents, peer, and other adults was also tested. Because there was loss than eighty-five per cent response on any part of the question, no observer reliability test was performed. A chisquare test was performed to determine if there were differences among the three groups of boys as to their degree of identification with adult figures other than parents. The differences were not significant.

Examination of the identification of the boys with parents, other adults, and peers, revealed a statistically significent difference. The boys identified more often with other adults than with theix own parents. There was less identification with peers than with parents.

What does a Delinquent Think are Obstacles Which He Needs to Overcome?

What the observer felt bothered the interviewee about himself was first considered. This was in terms of physical appearance, mental limitations, physical prowess, personal appearance, self-consciousness, shy or retiring personality, uncontrolled sggressiveness, nervousness, lack of self-confidence, doubts of self-worth, and lack of physical resources. The traits most frequently seen by the observers to bother 
the interviewees were uncontrolled aggressiveness and doubts of selfworth. These traits appeared significantly more frequently. A significant difference between the groups was noted in regard to physical prowess. The MacLaren boys rated highest, the parolees next, and the probationers last; however, the number of observations involved was small.

The question of what the interviewees thought bothered other adolescents about themselves was also examined. The same traits as listed above were used and a significant difference among traits obtained for 2.11 the boys, though the differences were not as marked. Again, uncontrolled aggressiveness and doubts of self-worth were most prominent. Lack of self-confidence was also noted. By inspection, differences between the groups of boys in regard to any of the traits were obviously not significant.

\section{What does a Delinquent Feel that He has to offer?}

First exarnined was whether the interviewee felt inferior or superior to his friends. A $\mathrm{z}$ test revealed acceptable reliability between the observers when the average deviation was considered though individual extremes differed significantly. A significant chi-square also was obtained among the groups of boys. The MacLaren boys were seen as feeling more inferior to their friends, the probationers were Intermediate, and the narolees more often felt superior to their friends. A chi-square was computed between probationers and parolees only, with non-significant differences. However, when the MacLaren 
boys were compared with the probationers alone and the parolees alone, significant differences were obtained. The MacLaren boys' feelings of inferiority accounted for all of the significant difference when the three groups were compared.

Three questions involving self-conception were also considered: first, what the interviewee felt other people liked about him; second, what the interviewee liked about himself; and third, what the interviewee felt he was good at. In these three questions, the following categories were considered: (a) physical skills; (b) mental abjilitys (c) personality; (d) moral qualities; (e) social skills; (f) leadership.

A significant difference was found between the traits in what the interviewees felt other people liked about them with personality rated highest, social skills next. Mental ability and physical skijls were also rated a noticeable number of times. Moral. qualities and leadership were rarely seen. The parolees were seen as being significantly higher than the other two groups in regard to feeling other people liked them for their physical skills. It should be pointed out that the number of observations involved was not great.

In testing what the interviewees liked about themselves a significant difference was obtained among the traits. Personality rated highest with physical skills and mental ability almost es important. Social skills were also noted as having some importance to the interviewees. A chi-square test between the groups of boys was used to detemine if there was a significant difference in regard to the interviewees' liking their own physical skills. This was significant. 
The parolees were markedly higher than the other fwo groups. The parolees liked themselves for having good physical skills and also felt that others liked them for the same reason.

In considering what the interviewees felt they were good at doing, it was found by a chi-square test that there was a significant difference between the traits. Physical skills and mental abilities were rated highly most often with social skills, personality, moral qualities, and leadership noted in that order. A difference among the groups of boys was found to be significant in regard to feeling that mental ability was one of their assets. The probationers ranked highest, the parolees intermediate, and the MacLaren boys lowest.

\section{What does a Delinquent see as an Ideal Society?}

In order to determine that delinquents seo as an ideal society, the observers considered the question of what the interviewee would do to remake the world given the following choices: (a) destroy the world first, $i_{0} e_{0}$ do away with the existing social or geographic structure; (b) change other people; (c) change self; (d) redistribute power: $(\theta)$ redistribute wealth.

Comparison of the traits revealed that there was a significant difference between the traits as seen by the observers, with changing other people markedly higher than the other tradts. Redistributing power was also noted as being iraportant. Differences between the groups were found to be significant in regard to redistributing wealth and redistributing power, with the parolees scoring highest on these two traits. 
What does a Dalinguent see as the Best Therapy for Him?

To determine the interviewees' ideas for the best therapy, the observers rated whether and how much the interviewee felt he had been helped by: (a) having some person listen to him talk; (b) having some person talk to him; (c) having money made available to him; (d) having some adult engage in activity with hims (e) thinking things out for himself; (f) finding activities for himsels.

Having some person listen to him talk and having some person talk to him were noted by the observers over eighty-five per cent of the time. A test of observer reliability on the first trait was computed by a $t$ test with a non-significant score of $t=.32$ obtained, indicating observer reliability. A score of $t=4.29$ was obtained on the second trait, indicating a lack of observer reliability. Differences betreen the groups of boys on these trajts were not significant. A chi-square test on the differences between all the ways the interviewees felt they had been helped was significant, with "having some person listen to them talk" rated highest. "Finding activities for themselves," "thinking things out for themselves," and "having peers engage in activities with then," were also important to the boys. A significant chi-square revealed differences between the groups of boys in the importance of having some aduIt engage in activity with them. The MacLaren boys were seen as regarding this as more important than the other two groups of boys. The number of observations involved here was small. 
A quastion of who the interviewee thought had helped bim gince he had been in trouble was rated by the observers with the following possibilities: (a) mothor; (b) father; (c) both perents 3 (d) peors 3 (e) siblings; (s) other relatives; (g) judge; (h) counselors; (i) coto tage parents; (j) teachers; (k) minister or priest; (l) other adults。

A chi-square test was significant among the above listed choices for the boys as a whole. Cottage parents were mentioned most often, counselors next, then mother, teacher, peers, and judges. The others wero chosen noticeably less often. In regard to counselors and cottage parents, significant chi-squares were sound between the groups of boys with counselors mentioned more often by the probationers and cottage parents by the parolees. Probationers, of course, would not have had contact with cottage parents since they have not had institutional expertence. Probationers were sean to be helped more often by other relatives and parolees by the judge than the other two groups. These differences were signiflcent.

\section{Genersl Remariss}

As stated oarlior, this project was an exploratory study utiliaing the technique of depth intezviow as a moans of elsciting new infome. tion regarding attitudes of juvenile delinquents. To evaluste the usefulness of the technique of dopth interview, statistical analyses were made of observer reliability. In other words, a consistency among the ratings of the observers would give some index of observer reliability. Two neasures of observer reliability were used. Fixst, 
a criterion of eighty-five per cent or better response by observers was established to select those questions for further statistical examination. Onewthird of the questions met this criterion indicating low observer reliability in two-thirds of the responses. Secondly, statistical tests were applied to the third of the questions which met the eighty-five per cent criterion. Observer reliability was high when this measure was applied. No specific one of the seven attitudinal areas demonstrated more observer reliability than another by this test, though there ware specific questions for which satisfactory observer reliability was not obtained.

A further analysis was made on the responses of the interviewees, to see whether there was a significant difference in the responses among the three groups of boys with reference to the seven areas explored. Statistical analyses failed to demonsirate any markedly consistent differences among the three groups of boys. Differences between the groups were tested when by inspection there appeared to be differences. This was done also for items in which the criterion of eighty-five per cent of observer response was not met。

Statistical tests were also performed to determine whether the possible categories into which observations could be scored under the different questions were meaningful. In general, it was found that there was not a chance distribution of the traits chosen by the oba gervers for the boys as a whole, except in regard to the boys' future personality traits. The expectation that the observers would see the boys as manifesting certain traits more often than others was met. It 
84

is logically impossible in this study to determine to what extent the traits observed were characteristics of the boys or of the observers. The following chapter will discuss in more detajl the concluslons roached as a result of the statistical analyses both in respect to observer reliability and differences among the groups of boys. In addition, the following chapter will speculate as to the meaning of the results in terms of Social Work as well as the possible implica. tions for further study. 
References

ISee Appendix for observers" schedule, page 113.

2Winer, Bo Jo, Statistical Principles in Experimental Design, MeGrawaHill Company, New York, 1962, po 13

3 In this instance, class of individuals refers to peers, teachexs, police, or other persons by whom the boy feels controlled. The results of the interviewees? responses are presented in Table II.

4 See Appendix for the formal statement of hypotheses and the statistical result, See pages 116 ff。

5 Student is $t$ tests were calculated to compare differences between the most extreme observer and the observer closest to the mean。 $\Lambda \mathrm{z}$ test was used to obtain a $\mathrm{z}$ score calculated from the difference between the grand mean and the mean of the deviations from the grand mean. See Wallis, Wo Allen and Robert, Henry Vo, Statistics: A New Approach, Glencoe, IIlinois, Free Press, 1962, po 362 Sf。 


\section{CHAPTER V}

\section{EVALUATION AND IMPLTCATIONS FOR PRACITCE AND FURTHER STUDY}

In this study two primasy findings were sought, one exploring at titudes among three groups of delinquent boys, the second ascertaining the reliability among the observers in making judgments regarding the boys" attitudes, as elicited by means of a depth interview technique. Findings indicated that certain attitudinal areas were found to be significantly different among the three groups of boys, but that the boys were more often alike in their attitudes than not. In two-thirds of the items the standards of reliability were not met, in that, fewer than eighty-five per cent of the cells were marked by the observers. Therefore, these items were not examined by statistical analysis. This chapter will discuss the valua and limitations of the study, some relationships of the findings to the literature, and implications as they relate to social work practice and further research.

In exploring the seven attitudes by means of the depth interview some new patterns and reactions were found, indicating that present conceptions may need revising and expanding to reflect more fully the delinquents' world. Ideas of treatment relationships and their effects warrant re-examination. There appears to be an inconsistency between the methods used by the helping professions in understanding and treating the delinquent, and the child's conception of his problem and what he sees as being helpful. Findings of this study indicate that further research in 2.13 seven attitudinal areas would shed much light on the problems and the treatment of delinquency. Such questions as the differential frame of reference of the delinquent and the element 
of society which concerns itself with delinquency, the value of in gtitutionalization as it exists today, the delinquent's view of the world about him, and the ability of the helping professions with present day techniques to treat the problem of delinquency are brought forth in the findings of this study.

Some relationship of the findings can be made with the litera. ture as reviewed in Chapter II. The inability for delinquent boys to project themselves into the future, as exemplified by our study, can be related to Grossbard's opinion that the delinquent is completely absorbed with the present and that the future is a nebulous concept and not sufficiently meaningful to influence his behavior. Further he is so engrossed in immediate gratification of his own degires that he is unable to formulate and work toward long tem goals。 (Chapter II, po 37)。 Sorenson attributes this inability to project themselves into the future to the accelerated tempo of current itfe which tends to make both the past and future increasingly different from the presento (Chapter II, p. 24)。

The absence of responses by the boys regarding their fathers, found in the study, can be correlated with the findings of Bandura and Walters, who attributed limited father identification as one of the influences in the development of aggressive behavior. (Chapter II, p. 28)。

Richard Jarvis states that there was frequently a temptation on the part of the therapist to get the child to do what the therapist thinks is right。 (Chapter II, po 4I). There may be a close 
correlation between this opinion and our findings, which indicates that delinquent boys are not interested in having someone talk to them. Possibly they interpret being talked to as an attempt to get them to do what the therapist sees as being right, even though this may not be the aimo

On the whole, the literature found numerous determinants of delinquency and it is difficult for the student of the problem to delineate the saliency and implications of all the findings. Findings in this study which indicato a need for further exploration will be pointed out in the following discussion.

The use of the depth interview as a means of aliciting information may be useful in future research. Most often studies are made in conjunction with treatment programs. In this study, however, the interviewees were aware of the fact that their responses would have no bearing upon their treatment, tending to lessen the degree of inhibition. Many studies are based upon the activities of delinquent boys and not upon the boys' orm attitudes and opinions. The depth interview affords the opportunity for a wide variety of responses regarding attitudes. Since the observers were not aware of the nature of the previous delinquent behavior, they were able to make judgments regarding the boys' subjective responses without bias from preconceived ideas. This method of investigation was unique to the boys since they had no previously learned modes of behavior by which to respond.

Though the population studied was small, information regarding the pertinent attitudinal areas for further research was easily 
formulated. However, from such a small numbar, no findings can be considered conclusions and must be supported or rejected by studies of larger samples of the population.

The stucy has certain other linitations. Tho criteria for selecting the subjects were that they must be of average intelligence and able to express themselves verbally. This category of boys may not be a typical sample of delinquent boys and therefore may not express the general attitudes of those in their group. However, the fact that they are of average intelligence and able to express themselves, does not in itself discriminate them from other boys. Also, they may be able to clearly express the attitude of the nonverbal boys in their groups.

More information could probably have been obtained if the interviews had been longer. Also, more basic feeling might have been examined if the level of depth in the interviews had been greater. Many pertinent and more personal subjects that might have been productive, such as feelings about sex, fantasies, dreams, etc. were not explored. Some areas were studied but could not be analysed due to the lack of observer reliability.

The factor of low observer reliablitity is an important aspect of the findings and needs to be examined further. Much information was elicited from the boys in each interview regarding the seven attitudinal areas under study. The observers attempted to fit the responses heard and observed into a structured schedulo which was devised for purposes of measuring statistically both the responses and the 
reliability of the observers. A certain lack of reljability of observers was found. In two-thirds of the questions not enough observers were able to make responses. What factors were operating to cause this low measure of observer agreement? Does this mean that social workers with varying past experience, but all undergoing the same educational training, cannot agree on the meaning of responses as elicited in this type of interview? Do social workers have such a diversity of opinion that, slthough they are trained, they must continually need checks on one another's judgments? Are social workers more effective when working with persons whose frame of reference and values are more similar to their own? Are techniques of interpreting responses so crude that, at this point in knowledge, higher observer agreement cannot be expected? Does this lack of agreement among the observers point out the value of having a social history regarding the elient, in making a valid diagnosis?

What do the findings of low observer reliability imply for social work education? Agreement of the meaning of responses made by a client is desirable in any social work setting for purposes of an effective diagnostic and treatment process. How can canons of reliability be inculcated in the social work curriculum? Ilow can new techniques, that would enable social workers to be more effective with clients whose frame of reference differs, be found and taught to prospective social workers? All of these are problems which need reovaluation in the light of the low observer reliability found in this study. 
It is possible that the factor of low observer reliability wes caused not by the social worker's inabillty to agree on judgments, but a matter of the technique of the study. In general it would seem that studies of this type should be careful to fit response categories to questionnaire categories. Due to limits of timo, only one pretest was done and at that time the original response schedule underwent considerable alteration. With more pretests it may have been possible to fit the response schedule even closer to the type of information generally elicited in the interviews, thereby facilitating observer reliability in marking the schedule.

More time may also have afforded the group the opportunity to discuss more carefully each item in the schedule, what its exact meaning was and how it should be scored. There is a question of how much time is needed in order to prepare a group of observers so that the opportunity for reliable responses is optimsl.

The depth interview technique itself presents certain problems, when there is an attempt to measure the responses on a quantitative basis. How much information should be elicited? At what point does the interviewer decide that enough information has been gained in order that the observers can make adequate judgnents? Is there a point of minimal and optimal return on the amount of information elicited and how can this be adjudged in a depth interview situation? What is the optimal ratio of amount of information elicited as compared to the large amount of data covered in the response schedule? How can the factor of individual differences among observers and their varied needs, 
as to amount of information needed before adequate responses are made, be controlled? Would longer intervievs increase observer reliability?

Though the interviewees were chosen for their abilit ty to relate and express themselves verbally, individual differences of boys must 2lso be considered. Some boys demonstrated a higher capacity in responding to the interview situation than others. In many instances boys found it difficult to express themselves in certain areas. As a result, the observers had to infer much of the information. Though the necessity of inference was expected, there were individual differences among the observers in making inferences.

It is the group's consensus that low observer reliability was primarily a result of the difficulty of marking quantitative schedules on the basis of depth interviews, as well as the semantic problems which arose in interpreting the response schedule. More pretests and longer time spent in interpreting the meaning of all items on the schedule, berore beginning the study may well have allevi.ated some of the problems presented. The question nevertheless remains, if reliebility could only be increased by naking conditions more objective and structured, what of the social worker's ability to agree on judgnents in the unstructured setting of the social agency?

Following is a resume of the findings of the study and the implications for practics and research as they pertain to each of the attitudinal areas. 
What is a Delinguent's Attitude Toward Authority?

In reviewing the boys' atti.tudes toward authority, it was found that members of all three groups felt more controlled by their own emotions, and clesses of individuals. The classes of individuals most often referred to were: adults in general, police, peers, and teachers. (Table II, Chapter IV). They were more resentful toward these classes of individuals than specific persons. More resentment was expressed toward physical punishment and being detained than other forms of punishment. The only significant difference found among the groups of boys was that the fecLaren boys felt more resentment toward theix peers than did the other two grouns.

To the extent that these findings are valid, one could assume that delinquent boys do not feel controlled by specific indivicuals such as their parents or parental surrogates. It also indicates that they do not tend to establish individual relationships. This study points out that they express most resentment toward the groups they see as attempting to control them. Also they feel most controlled by their own emotions。

Questions that arise from this area of investigation are these。 Although they resent those whom they see as attempting to control them, does this indicate that these controls are ineffectual? Doss it also indicate that corporal punishrent and detention are ineffective? Doss the implication that the delinquent fools controlled by his own emotions signify an inability to identify with an ego ideal or establish 
94

meaningful relationships with other Individuals? Does the fact that ant the boys interviewed have recently come into contact with different classes of authority Pigures explatn their resentment? Since they feel most controlled by their own emotions, what psychological effect does 'acting out' have upon them?

This information points up a need for studies regarding the attitudes of non-delinqueat children toward authority. Do nonmdelin. quent ahildren feel controlled by their own emotions and resent certain classes of individuals? Are the controls of non-delinquent so intexnalized that they do not cone into conscious conflict with authority?

Another area where further study is needed is regarding the effect that resentment toward peers has upon the institutionalized child and whether or not this has a positive or negative effect upon his rehabllitation.

of what is a Delinquent Fearful?

There were less than $85 \%$ observer resnonses in the area of fear, which leaves our findings tenuous. However, this does not irdicate that the observers who did respond were not makirg valid judgments。 This must be deternined by future studies. No significant differences were found among the three groups tested but there were significant differences found between the traits tested, which were: fear of Interpersonal relationships, inanimate objects, and feelings of self. of these traits, all three groups expressed greater fear of interpersonal 


\section{5}

relationships. Also, probationers revealed a greater foar of natural phenomena than the other taso groups. There were no significant differences among the observers or groups of boys regarding theix fear of loneliness.

The lack of information elficited in the area of fear could be Indicative of the fact that boys are hesitant in discussing their fears because it is not considered a macculine trait in our society。

The expression of fear of interpersonal relationehips by all the boys might indicate a feeling of anomie and rejection by society. This also might suggest a lack of positive identification with other people. One might speculate that boys who have been committed to MacLaren would have greater fear of interpersonal relationships and loneliness but this did not prove to be the case.

The leck of abserver responses in this area might indicate that delinquent boys do not have or are unable to express fears. A study of the fears of non-delinquent children might prove fear or the lack of fear to be an important factor in delinquency.

What are a Delinquent's Aspirations for the Future?

An exploration of the boys' future aspirations was made in an effort to ascertain if these were realistic and if further study regarding educative practices would be indicated. The major findings Implied that members of all three groups had little conception of how they saw themselves in the future in terms of personality traits. 
When asiced to choose preferrec future roles, nembers of all three groupe chose occupational roles, school roles, family roles, and military service in that ordor. In terras of future asplrations, as related to any 1dentification figures, there were no significant differences found among the three groups, but a significant differ. ence was found to exist In terms of what identification sigures were chosen. Other achlts, as 1dentification figures, were chosen most frequently. Parentel figures were chosen second and peers, thirdo

These findings present certain issues for future examination and exploration. Apperently an experience in an institution does not Influence the boys' aspirations for the future, either in terns of personality trait, future role conceptions or identity figures. The responses elicited indicated a vagueness on the part of the interviewees regarding the future. They cowld neither see thenselves as happy or unhappy in the future, nor did they think future femily roles were important to them at this time.

Thoughts of the futurs were nost often interpreted by the boys to mean specific occupational roles and a wide variety of occupations were mentioned. Does this mean that the boys see society as so materialistic that only specific occupations are meaningful? Have schools and other institutions stressed the importance of future work and gaining material goods to such an extent that future personalsty traits and family roles become of secondary importance? $O r$ is this a factor to be found only among delinquents? Does the fear of interpersonal ralationships, as expressed by the majority of boys, contribute to 
their inability to rake future plans in terms of personality tratts and family roles?

The fact that boys in a.17 three groups chose as identification figures other adults, parents and peers, in that order, shous that persons outside the family are very influential in the boys' choices of future roles. Under what circumstance a person is chosen as an identity figure is an important factor that should be considered for future study so that the intricate process of identification can be used in the most edvantageous manner in helping juveniles to make choices about their future.

The inability for delinquent boys to project themselves into the future appears, possibly, to be an important factor in delinquency. It could be accounted for on the basis of japulsiveness of the deline quent child and his inabilitty to establish goals and starive toward their consuranation. If this is the case, more emphasis on realistic choice of occupation and future roles should be an integral part of the training program for delinquent boys

A study of the aspirations of non-delinquent children could prove to be fruitful. Do non-delinquent boys have a more realistic conception of the future? Do they also see the future foremost in terms of occupation roles? How important is the identification process of an acult figure in the non-delinquent's choice of future occupation? These are all questions that could be examined in future studies. 
What Does a Delinquent Think are Obstacles Which He Needs to Overcone?

of particular interest to the groun, regarding what obstacles delinquents feel they have to overcore, was whether or not these obstacles were of an external or internal nature. Finoings indicated \& significant difference among the traits. Hembers of all three groups were most concerned by their own uncontrolled feelings and doubts of self-worth. The boys in Macharen were more concerned about their physical prowess than were the parolees and probationers. All three groups felt that other boys were also concemed about uncontrolled feelings and doubts of self-woxth.

From the foregoing one might assune that delinquent boys see their problems as being internal, and characterized by lack of self-control. This raises the question as to whether there is a direct correlation between feelings of worthlessness and self-control. Would the enhancement of self-esteem lead to better inner controls?

The only significant difference among the groups was found in the MacLaren boys who revealed a greater concern for physical prowess。 This might be accounted for on the basis of the pressures of group living and an inability to escape these pressures. In this situation a boy must face conflict with his peors, and physical prowess becomes a mode of resolving the conflict. If this is true, would institutionalization only tend to increase the feeling of selfworthlessness in the boys who are physicalizy inadequate? This may point up the importance of physical fitness and athletic endervors in institutions for 
delinquent boys in the rehabilitative process. Or, should the rehabilitative process be more concerned with remanneling uncontrolled aggressions, or attempt to resolve them through therapy?

Further questions arise. Do non-delinquent boys experience this same degree of uncontrolled feelings, but are able to express them in socially acceptable ways? Do all adolescents see obstacles in terms of their own uncontrolled feelings, or is this only an issue found among delinquents? Do delinquents see societal obstacles, but are unable to express future oroblems in these terms? What is the relationship between intelligence and verbal ability (the criteria for selection of interviewees) and seeing obstacles in terms of internal factors as opposed to external factors? Do loss intelligent boys project their problems upon external factors to a higher degree? Do feelings of gujit have a correlation with seeing obstacles as being of an internal nature? Research and further study are neoded to more fully understand the implications of these findings.

What Does a Delinguent Feel that He Has to offer?

The only significant finding in what delinquents have to offer was in the area of self-concepts. Our questions did not elicit concrete reswonses regarding future roles. However, certain relationships were found to be significant in regard to the delinquent boy. In diseussing what the interviewees liked about themselves, the boys mentioned the following traits in order of importance: personality, 
physical skill, mental ability and sociel skills. Moral qualities and leadership were mentioned infrequently. In discussing feelings of infertority and superiority toward sriends, the MecLaren boys expressed greater feelings of inforiority in relation to their peers. The parolees were found to feel more sats.sfied with their physical skills than were the other two groups. The probationers felt nore competent mentally, followed by the parolees. The HacLaren boys folt least competont mentally.

These findings could be interpreted to mean that the program at Maclaren is adept at developing the boys' physical skills, which the boys use in their peer relationships upon returning to society. The variation in the feelings of mental competency by the three groups might be pertinent and a subject for further study.

The fact that little significant information was elicited may be related to our findings in the area of aspirations for the future. Delinquents were unable to project themselves into the future; therefose, 1t seens reasonable to assume that they would be unable to visualize what they had to offer.

\section{What Does a Delinquent See as an Ideal Society?}

The delinquent's concept of an ideal society was explored in order to loarn how he percoives society. All the interviewees wero scored remaxikably high in the area of changing other people and redistrsibuting power in order to create an ideal society. The parolees wers scosed 
significantly higher in advocating redistribution of wealth and powero

This may indicate that when asked about obstacles indirectly, as contrasted to asking what obstacles the boys themselves feel they must overcome, the delinquents project their problems upon society and, in this instance, do not see their own behavior as an issue. The fact that parolees were scored highest in redistributing wealth and power, may imply that institutionalization increases their conviction that society is a contributory agent to their situation, or that they are facing obstacles more directly. A more detailed study of a large population of delinquents would be productive in determining whether or not these attitudes are a common factox in delinquency. If this is true, methods of treatment and prevention would need to focus on the delinquent's conception of society and whether he needs to see himself as a more integral instrument in his milieug or whether society's institutions are meeting his needs.

Does the delinquent see himself as the victim of society and in order to cope with these problems, acts out? What is the meaning of the dichotomous findings, that when interviewees were asked what obstacles they must overcome they interpreted this as internal (own un controlled feelings), but when asked what they see as an ideal society, the problems were seen as being external (changing other people and redistributing power)? 
What Does a Delinquent See as the Best Therapy for Him?

In investigating what dolinquents see as being the best therapy, It was found that members of all three groups of boys were rated as responding markedly high in the area of having someone listen to him. Other therapeutic processes chosen in order of importance were: finding activities for himself, thinking things out for himself, and having peers engage in activities with hime Since being in trouble, Maclaren boys and parolees mentioned cottage parents as most helpful. to them. Frobationers mentioned court counselors as being most helpful. Other helping persons mentioned by all three groups, in order of importance were: mothers, teachers, peers, and judges.

One of the most outstanding flndings in this aspect of the invese tigation is that counselors and cottage parents were found to be most helpsul, with mothers considered second, but fathers were not mentioned as helping persons at 217. The fact that most of the helping persons were seen as being outside the family may indicate severe deprivation in family relationships. The fact that fathers were not mentioned would raise questions regarding the boys' process of masculine identification. Does the delinquent boy identify with his father or a father surrogate? Again, a study of the attitudes of nondelinquents would be necessary to deterrine whether or not these are unique characteristies of delinquent boys.

It seems significant that Maciaren counselors and parole officers were not mentioned as helping persons, though court counselors were 
mentioned by probationers. Does this indicate that parole officers and counselors at MacLaren aro not in close enough contact with the boys or does it mean that cottage parents, who were often mentioned as helping persons, fulfill this need as a result of theix close proximity to the boys? If this is true, has the role of the cottage parent in treating the delinquent boy been underestimated? It may also be possible that boys living in a structured situation are not predisposed to counseling.

Most interesting was the fact that few of the helping orofessions were mentioned as being therapeutic agents. Psychiatrists, social workers, psychologists, and ministers were not mentioned at all.

Members of all three groups felt the most holpful technique was having someone listen to them, as opposed to having someone talk to them, or having someone engage in activity with them. It seems extremely important that the helping professions be more cognizant of the boys' desire to express themselves verbally as a therapeutic process and their hesitancy in boing talked to or given advice. On the other hand, does the fact that the boys designate specific persons as being therapeutic agents indicate that these are helping persons in actuality? At the same tine do the boys' desires to have sameone listen to them result in the most efficacious therapy?

\section{Conclusiong}

This has been an exploratory study, the purpose of which was 
twofold. The first, an attempt to elicit new information from juvenile delinquents regarding seven attitudinal areas; the second, to evaluate the technique of the depth interviews. Fifteen boys were interviewed in depth; five probationers, five institutionalized boys, and five parolees. Each interview was judged by eight observers using a schedule which was the basis for statistical analysi.s. Two primary hypotheses were tested.

1. There is no significant difference in judgnent among the observers regarding the proportion and degree of responses to the seven attitudinal areas tested.

2. There is no significant difference among the three groups of boys regarding their attitudes in the areas of authority, fear, aspirations for the future, what they feel they have to overcome, what they feel they have to offer, what they see as an ideal society, and their iceas for the best therapy。

Observer reliability was low in that only one-third of the quesfitons on the response schedule were answered by enough observers to warrant a statistical analysis. These findings suggest questions centering about the practice of social work, as well as nethods of judging responses statistically, as elicited in a depth interview。

It was found that attitudes among the three groups of boys were more of'cen alike than different, though there were scme attitudinal axeas where members of the three groups differed. The most signifin cant findings were that adolescents interviewed tend to fear interpersonal relationships, lack ability to project themselves realistically 
Into the future, fear their own uncontrolled feelings and, in the area of treatment, desire to have someone listen to them talk. Findings regarding the seven attitudinal areas, observer reliability and the use of the depth interview point out certain considerations. The helping professions, in their attempt to learn more regarding the dynamics of delinquent behavior, as well as how to help the delinquent modify his behavior so that his social functioning may improve, will be interested in these intrinsic questions not resolved by the study.

Can a depth interview be useful for purposes of quantitative analysis?

Can social workers be trained to perceive similarly, material elicited in interviews?

Can one interview, without a social history, be a valid tool for making judgments about an interviewee's attitudes?

How can delinquents' fears of interpersonal relationships and fear of uncontrolled feelings be dealt with in the casework process?

What is the value of institutionalization in the rehabilitative process?

How can institutionalization become a better tool in the therapeutic process?

How can society's institutions, educational and therapeutic, help the delinquent see his future more realistically? 
Theory and Background

Aichhorn, August, Wayward Youth, New York, The Viking Pross, 1935.

Bandura, Albext, and Walters, Richard Ho, Adolescent Aggression, A Study of the Influence of Child Training Fractices and Family Interrelationships, New York, The Ronald Press, 1959.

Barron, Milion L., The Juvenile in Delinquent Society, New York, Alfred A. Knopf, 19540

Beck, Bertram Mo, "The Exiled Delinquent," Chjldren, Vol. 2, No. 6, November-December, 1955. pp. 208-212

Bennett, Ivy, Delinquent and Neurotic Children, A Comparative Study, New York, Basic Books, 1960.

Bloch, Herbert A, and Flymn, Frank To, Delinquency--The Juvenile Offender in America Today, New York, Random House, 1956.

Cassel, Russell N., "The Phoentx Youth Study Propossl for Delin. quency Reduction," Joumal of Educational Sociology, Vol. 33 , No. 2, October, 1959. pp. $67-72$

Cavan, Ruth Shonle, Juvenile Delinquency: Development, Treatment, Control, Philadelphia, J. B. Lfppincott Co.s 1962。

Chwast, Jacob, "Value Conflicts in Treating Delinquents," Children, Vol. 6, No. 3, May-Juno, 1959. pp. 95-100

Class, Norris E., Juvanile Delinquency Trends and Their Implications, unpublished paper given to Portland chapter of the Oregon Social Welfare Association, October 17, 1962.

Cohen, Albert K., Delinquent Boys, The Culture of the Gang, Glencoe, IIIinois, The Free Press, 1955.

Daniels, Lincoln, A Look at Juvenile Delinquency, Washington, U。S。 Department of Health, Educationg and Welfare, Social Security Administration, Children's Bureau Publication No。 380, 1960 .

Eissler, Kurt Ro, (ed.), Searchlights on Delinguency, Now York, International Univarsitios Press, 1935. 
Elliott, Delbert, Sociological Contributions to the Theory of Dslinquency, unpublished paper given to the University of Oregon Juvenile Court Institute, Aupust, 1963.

English, O. Spurgeon, and Pearson, Cerald H. J., Emotional Problems of Living, 3rd edichion, New York, Wo W. Norton and Co., I963.

Erikson, Brik $\mathrm{H}_{0}$, Childhood and Society, Ner York, Wo Wo Norton and Co., 1950。

\section{"The Problem of Ego Identity," Psychological \\ Issues, Vol. 1, No. I, honograph 1, 2959. pp. TO1-171}

Gueck, Shelcion and Eleanox, Family Environment and Delinguency, Boston, Houghton-Miffritin CO., 1962 .

Gottfredson, Don Mo, 흐 al., Base Expectancy, Californja Instituthon for Women, Vacaville, California, Institute for the Study of Crime and Delinquency, September, 1962.

Crossbard, Hyman, "Ego Deficiency in Delinquents," Social Gasework, Vol. 43, No. 4, Apri.1, 1962. pp. 171-178

Hall, Calvin S., and Lindzey, Gardner, Theories of Personality, New York, John Wiley and Sons, 1957。

Jersild, Arthur To, The Psychology of Adolescence, 2nd edition, New Yorks The Macinizin Co., 196\%。

Kveraceus, William C., "Forecssting JuFenfle Delinquency," Journal of Education, Vol. 238, No. 4, April, 2956. pp. 1-43

KJle, John, "Hearing on Juvenile Delinquent Control, Bill 8028," U. S. Conpressional Record, Vo1. 107, 87th Congress, August 30, 1961. $\frac{\mathrm{pp} .6318-6320}{20}$

MacKay, James $R_{0}$, "Problem Drinking Among Juvenile Delinquents," Crime and Delinquency, VoI. 9, No. 1, January, 1963. pp. 29-38

Nays, John Barron, On the Threshold of Delinquency, Livexpool, Liverpool University Press, 1959.

Meier, Blizabeth $G_{0}$, "An Inquiry into the Concepts of Ego Identity and Identity Diffusion," Social Casework, Vol. 45, No. 2, Fobruary, 1964. pp. 63m70 
National Research and Information Center on Crime and Delinquency, Current Projects in the Prevention, Control, and Treatment of Crime and Dalinquency, New York, National Council on Crime and Delinquency, Soring, 1962, and Winter, 1962-63.

Neumeyer, Nartin Ho, Juvenile Delinquency in Modern Society, Princeton, New Jersey, Do Van Nostrand Co., Ig6I.

Peck, Harris Bo, and Bellsmith, Virginia, Treatment of the Delinquent, New York, Family Service Association of America, 1962。

Perlman, Io Richard, Delinquency Prevention--The Size of the Problem, Washington, U. S. Department of Health, Education, and Welfare, Social Security Administration, Children's Bureau Publication, No. 4, 2.960 。

Pfautz, Harold W., "Near-Group Theory and Collective Bohavior: A Critical Refornulation," Social Problens, Vol. 9, No. 2, Fall, 1961. pp. 167-174

Polk, Kenneth, The Metropolitan Youth Cormission Delinquency Study, Preliminary Repork, lugene, oregon, unpublished.

Polsky, Harold W., Cottage Six, The Social System of Delinquent Boys in Residential Ireatment, New York, Russeli sage Foundation, 1962.

Progoff, Ira, Depth Psychology and Yodern Man, New York, The Jullan Press, $1957^{\circ}$

Reiss, Albert J., and Rhodes, Albert Lo, "The Distribution of Juvenile Delinquency in the Social. Class Structure," American Sociological Roview, Vol. 26, No. 5, October, 1961。 pp.720-732

Robison, Sophia Mo, Juvenile Delinquency-Its Nature and Control, New York, Holt, Rinehart and Winston, 1960 .

Short, James Fo Jro, et al., "Behavior Dimensions of Gang Delinquency," American Sociological Roview, Vol. 28, No. 3, June, 1963. pp. $411-429$

Sorenson, Roy, "Youth's Need for Challenge and Place in Society," Children, Vol.9, No. 4, July-August, 1962。 pp. 13l-138

Spangler, Joseoh A., Expanding Services for a Growing Comminity, (The Juventle Court, Juvenile Departinent, and Detention Home of Lane County, Oregon), New York, National Probation and Parole Association, 1955. 
Spanglex, Joseph A., Adult Parole and Probation - 1958, New York, National Probation and parsole Association, 1958.

Steiner, Lee $R_{\bullet}$, Undesstanding Juvenile Delinquency, New York, Chilton Company - Book Division, 1960.

Studt, El21.ot, "An Outline for Study of Social Authorl ty Factors in Casework," Soci.al Casework, Vol. 35, No. 6, June, 1954. pp. 23l-237

Teeters, Negley $K_{0}$, and Reinomann, John Otto, The Challenge of Delinquency: Causation, Treatment, and Prevention, Ner York, Frentias llall, 1950.

Toby, Jackson, "Delinquency and Opportunity, review of book by Richard A. Cloward and Lloyd E. Ohlin," British Journal of Sociology, Vol. 12, No. 3, September, 1961. pp. 282-289

Wassernan, Sidney, "Casework Treatment of the Neurotic Delinquent Adolescent and the Cosnovisive Yother," Social Casework, Vol. 43, No. 9, November, 1962。 pp. 48504492

Wertham, Fredric, Seduction of the Innocent, New Ioric, Rinehart and Co., 1954.

Witmer, Helen $\mathrm{L}_{\circ}$, Dalinquency and the Adoloscent Cxisis, Washington, U. S. Department of Health, Eảucation, and Welfare, Social Security Administration, Children's Bureau publication No. II, 1960.

Witmer, Helen I., and Kotinsky, Ruth, (eds.) Ner Perspectives for Research on Juvenile Delinquency, washington, U. S. Dapartment of Health, Education, and Welrare, Social Security Adrinistration, Children's Bureau publication No. 356, 1956.

Yablonsky, Lewis, The Violent Gang, New York, The Macmillan Co., 1962. 
Methodology - Obtaining and Recording Data

Adams, J. Stacy, Interviewing Procedures, A Manual for Survey Interviewers, Chapel Hill, Uns versity of North Carolina Press, 1958.

Bucher, Rue, et al., "Tape Recorded Interviews in Social Research," Amerrican Sociological Review, Vol. 21, No. 3, June, 1956. pp. $359-364$

Caplow, Theodore, "The Dynamies of Information Interviewing" American Journal of Sociology, Vol.62, No. 2, September, 1956. pp. 165-171

Dohrenwend, Barbara So, and Richardson, Stephen A., "Analysis of the Interviewer's Behavior, "Human Organization, Vol. 15, No. 2, Sunner, 2956. pp. 29-32

Eaton, Joseph Wo, and Polk, Kenneth, Measuring Delinquency, A Study of Probation Department Referrals, Pittsburgh, Jniversity of Pi.ttsourgh Press, 1961.

Fellin, Phillip, "The Standardized Intexview in Social Work Research," Social Casework, Vol. 44, No. 2, February, 1963. pp. 81.85

Cordon, Raymond Lo, "Dinensions of the Depth Interview," American Journal of Sociology, Vol.62, No.2, September, 1956. p0. 158-164

Hamovitch, Maurice Bo, et al., "Research Interviewing in Sensitive Subject Areas," Soci.al Work, Vol. 8, No. 2, April, 1963. pp. 3-18

Hyman, Herbert $\mathrm{H}_{\circ}$, et al., Interviewing in Social Research, Chicago, University of Chicago Press, 1954。

Ienski, Gerhard E., and Laggett, John $C_{0}$, "Caste, Class, and Deference in the Research Interview," Americen Journal of Socto.logy, Vol. 65, No. 5, Narch, 1960。 pp. 463-467

Merton, Robert $K_{0}$, et ․… The Focused Interview, A Manual of Prob2ems and Procedures, Giencoe, IIlinois, The Freê Press, I956。

Pode1I, Lawrence, "An Interviewing Problem in Values Research," Sociology and Social Research, Vol. 4I, No. 2, November-December, 1956 . pp. $123-126$ 
Polansky, Norman Ao, Social Work Research, Chicago, University of Chicago Press, 1960.

Prigmore, Charles S., "An Analysis of Rater Relisbility on the Glueck Scale for the Prediction of Juventle Delinquency," The Journal of Criminal Law, Criminology and Pollce Science, v01. 54, No. I, Narch, 2963。 pp. 30-41

Richardson, Stephen A., "The Use of Leading Questions in NonSchedule Interviews," Hunan Organigation, Vol. 19, No. 2, Summer, 1960. pp. 86-8?

Spergel, Irving, "An Exploratory Research in Delinquent Subcultures," Social Service Review, Vol. 35, No. 1, March, 1961. pp. $33-47$

Whyte, William $F_{0}$, "On Asking Indirect Questions," Hunan Organizetion, Vol. 15, No. 4, Winter, 1957. pp. 21-23

Methodology - Statistical Interpretation

Axkin, Herbert, and Colton, Raymond $R_{0}$, Statistical Methods, 4th edition, New York, Barnes and Noble, 1939.

Dixon, Wilfred J., and Hessey, Frank $J_{0}, J r_{0}$, Introduction to Statistical Analysis, 2nd edition, New York, licGraw-Hili - Book Company, 195\%

Hoel, Paul Go, Blementary Statistics, New York, John Wiley and Sons, 1960。

Maxk, Mary Jouise, Statistics in the Making, A Primer in Statistical Survey Method, Columbus, Ohio, Bureau of Business Research, CoIlege of Commerce and Administration, Ohio State University, 1958.

Ostle, Bernard, Statistics in Research, Basic Concepts and Techniques for Research Workers, Ames, Iowa, Iowa State Uni versity Press, 1954. Siegel, Sidney, Noaparametric Statistics
Sciences, New York, Wickraw-Hill Book Company, $\frac{\text { the }}{1956 .}$

Wallis, Wo Allen, and Robexts, Harry $\nabla_{0}$, Statistics, A New Approach, Glencoe, Illinols, The Free Press, 1962.

Winer, B. J., Statistical Principles in Experimental Design,

New York, MeGraw-Hill Company, 196\%. 
APPENDICES 


\section{INTLRVIEWER'S SCHEDULE}

I. Atthitude toward authority.

1. How would you act if you were in charge of a group of boys?

2. How do you feel about punishment? How does it affect others you know who recelve punishment?

3. When people don't control themselves, what do you think is the best thing to do?

4. Do you feel that people in charge of things have let you make choices?

5. If you could "toll someone off" who would it be?

6. How do you feel about laws for minors, such ass smoking, curfew dxiver's license, drinking, etc。?

II. Of what are dolinquents fearsuli?

1. What is the most erightening thing that could happen to you?

2. What makes people afraid?

3. What are boys your age most afraid of?

40. Do you feel that everyone is lonely sometime in life?

III. What are their aspirations for the future?

1. What kind of person do you want to be when you get older?

2. What do you expect to do in the next $5,10,25$, etc. years?

3. If you could be anything you wanted to be, what would it be?

4. How important do you think money is? 
IV. What do delirquents feal they have to ovarcone?

1. What "bugs" you most about yoursalf and other gwrs?

2. What do you think your frlends feel is the most difficult thing about gatting along in this world?

3. What do you think is your biggest problem in years to come?

4. Do you have any faults that other people notice quite of ten that you know you could improve on?

V. What do delinquents feel they have to offer?

2. What are you good at doing?

2. What do you think you could do if there were nothing standing in your wey?

3. In a group of friends do you feel there are some things that you could do better than they can?

4. What do people usually ij.ke about you?

VI. What do delinquents see as an ideal society?

1. If you could remalke the world, whst is the first thing you would do?

2. What could people of all races and religions do to get along with each other?

3. Who do you thinik are the three greatest people in the United States?

VII. What do delinquents think is the best therapy?

1. How do you think you could be helped most?

2. What do you think could best help kids in ganeral?

3. Do you 2ike adults to listen to you? Do you like to listen to acults?

4. What has soneone done that you feal has helped you? 
OBSLRVER'S SCHEDULE 
TESTED HXPOTHESES

Delinguents' Attitudes Toward Authority

Question \#3

$\mathrm{H}_{\mathrm{OQ}}$ : There is no significant difference in the ratings of the observers in regard to the intervieweos' feelings toward boing controlled by their own emotions.

$\mathrm{H}_{\mathrm{Oa}}$ : Not rejected.

$\mathrm{H}_{\mathrm{ob}}$ : There is no signtificant difference among the categories of boys in regard to their feelings of being controllod by their own emotions.

$\mathrm{H}_{\mathrm{ob}}$ : Not rejected.

$\mathrm{H}_{\mathrm{oc}}$ : - oa class of individuala.

iI ${ }_{O C}$ : Not rejected.

$\mathrm{H}_{\mathrm{od}}$ There is no significant difference among the traits as rated by the observers.

Hod Rejected.

\section{Question \#6}

$\mathrm{H}_{\mathrm{OQ}}$ : There is no significant difference among the categories of boys with regard to their feelings of resentment toward the world in general.

$\mathrm{H}_{\mathrm{og}}:$ Not rejected.

$\mathrm{H}_{\mathrm{Ob}}$ : There is no significant difference among types of resentment shown by the boys.

$\mathrm{H}_{\mathrm{ob}}$ Rejected. 
Schedule for Depth Interview

with Male Delinquents

\section{Authority Attitudes}

1. Interviewee's attitude toward interviewer over entire interview

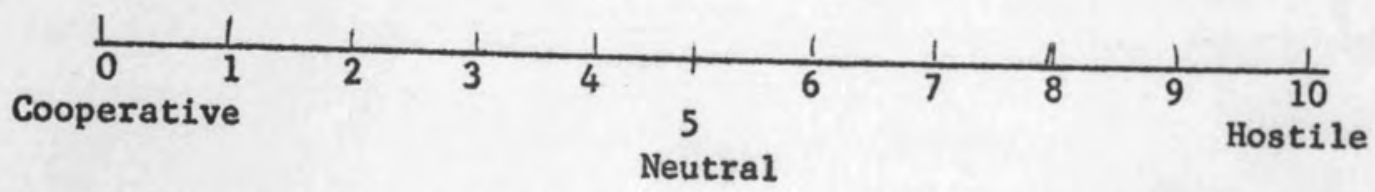

2. Interviewee feels he can make choices in regard to his actions
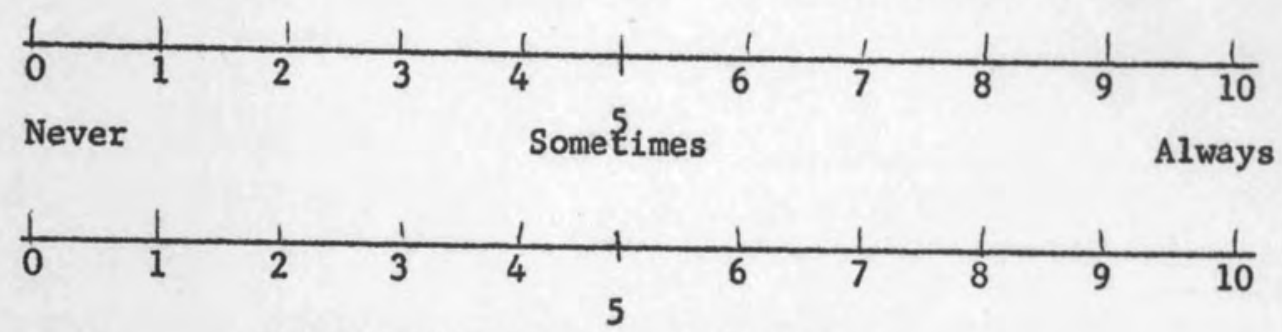

Degree of Intensity of Response

3. Interviewee feels controlled by the following: (Rank in order of importance to interviewee)

$\square$ a. A specific individual (specify)
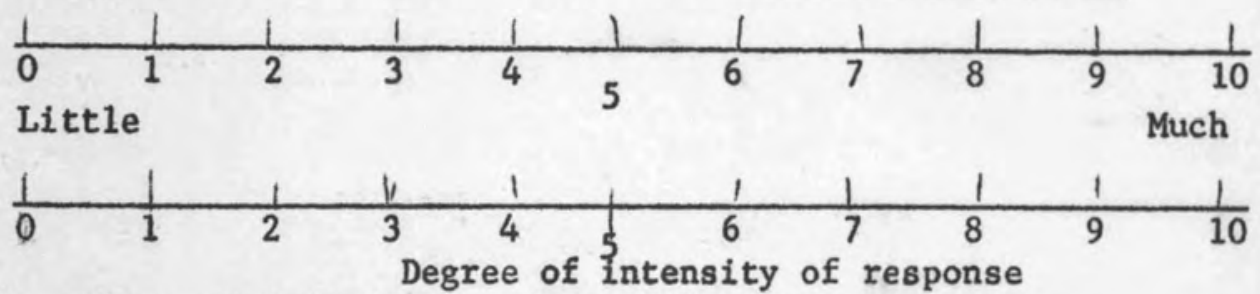

$\square$ b. Class of individuals (specify)

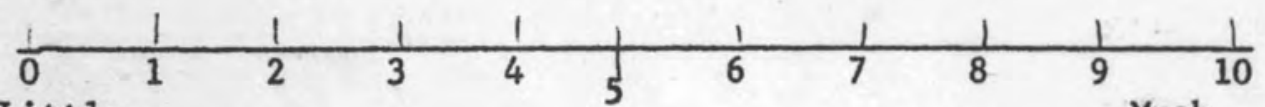

Little

Much

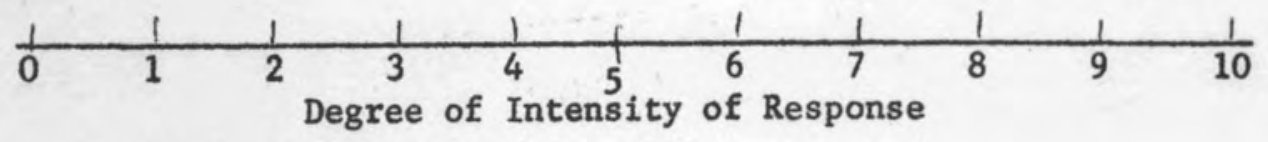

c. World in General
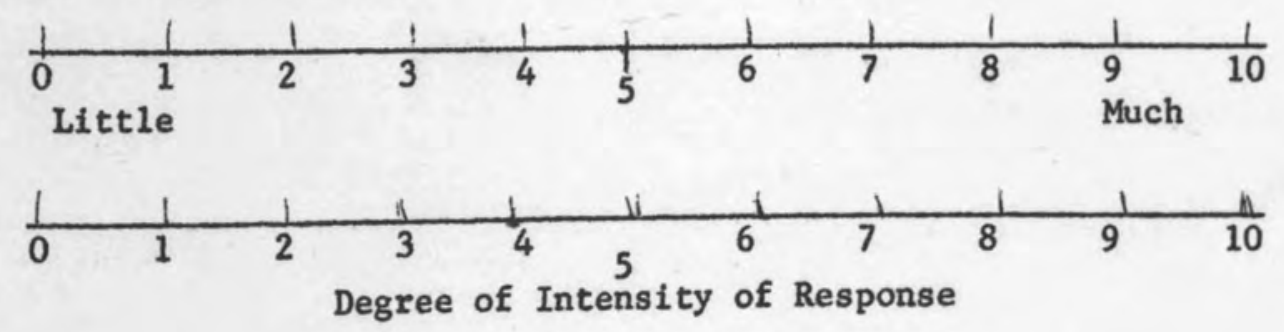
T. $d$. By own emotions

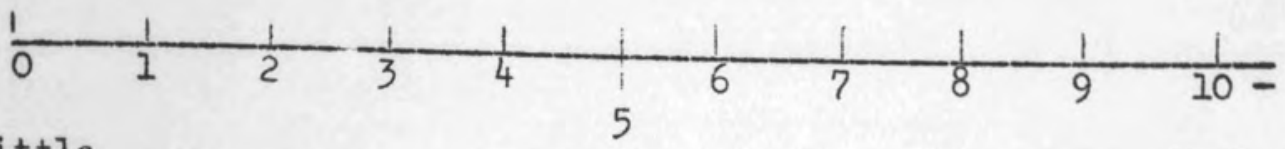

Little

Much

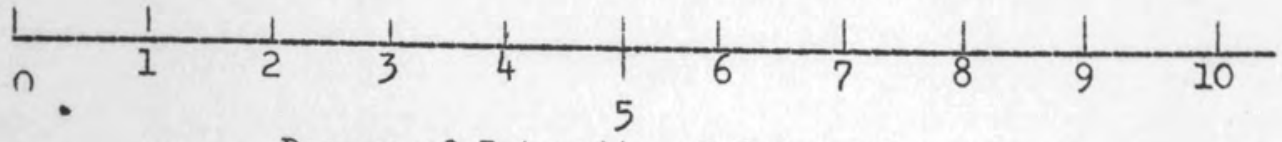

Degree of Intensity of Response

Te. other (specify

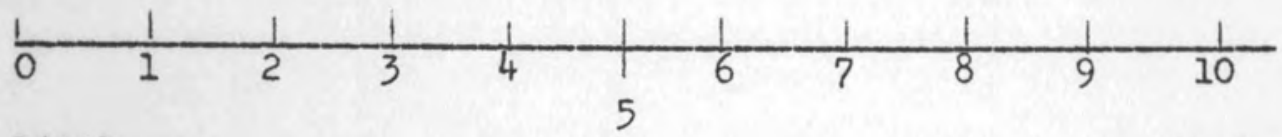

Little

Much

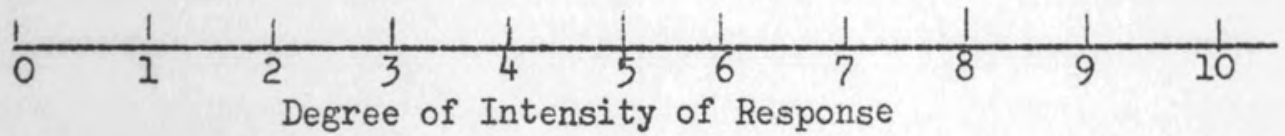

4. How much does interviewee think he is actually controlled by: (Rank in order of importance to interviewee)

a. A specific Individual (specify

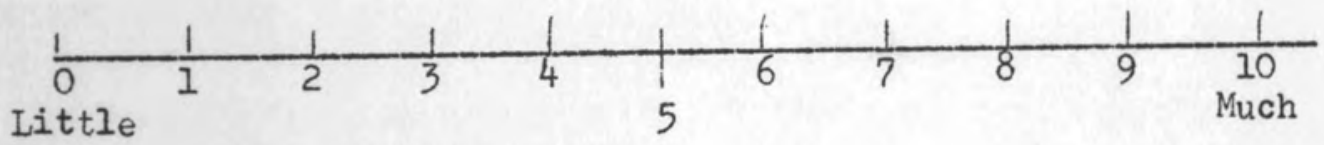

Tb. Class of individuals (specify

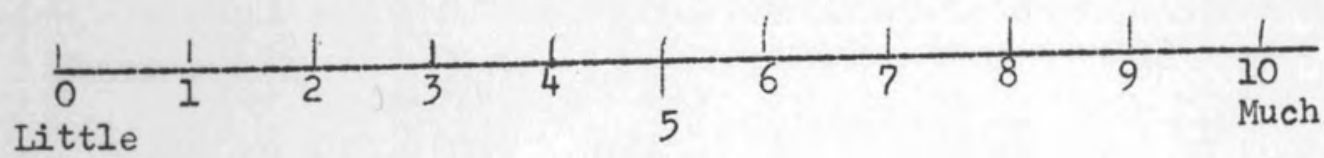

c. World in general

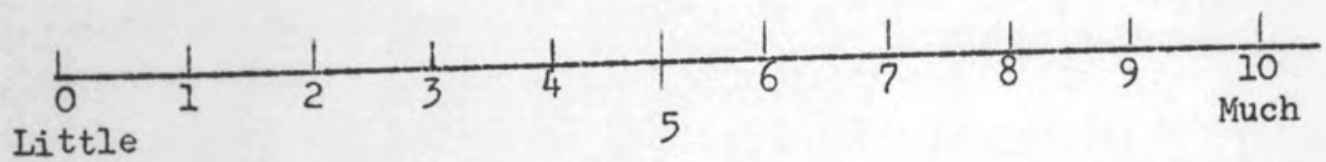

id. Own Emotions

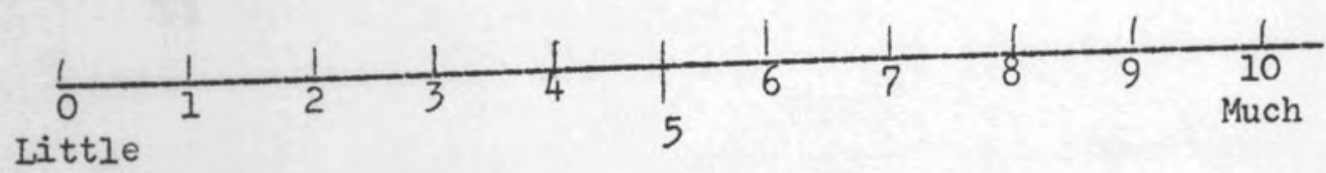

We. Other (specify

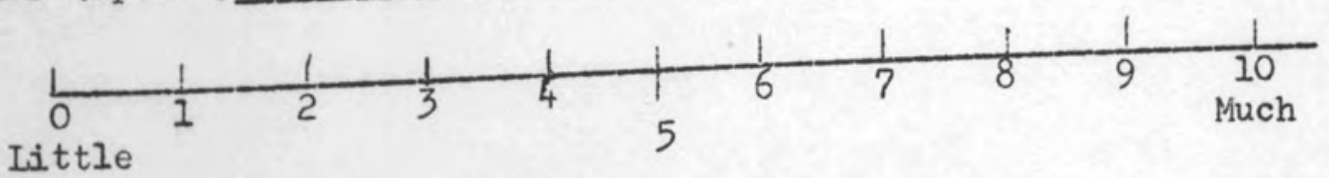


5. How much does interviewee think others attempt to control him? (Rank in order of importance for intervicwee)

a. A specific individual (specify

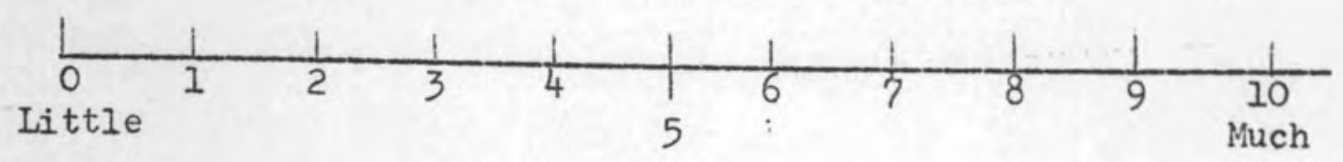

b. A class of indificuals (specify

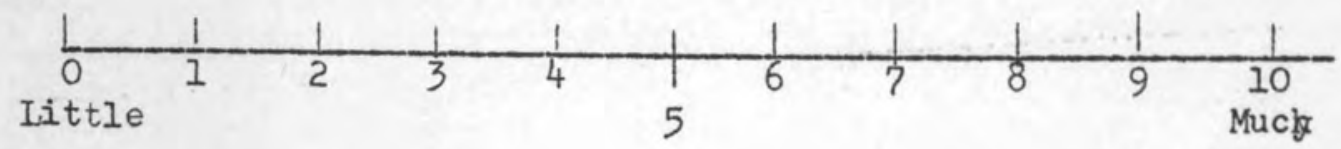

De. World in general

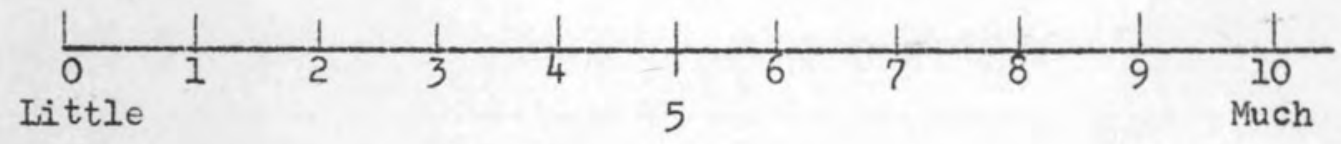

Td. Own Emotions

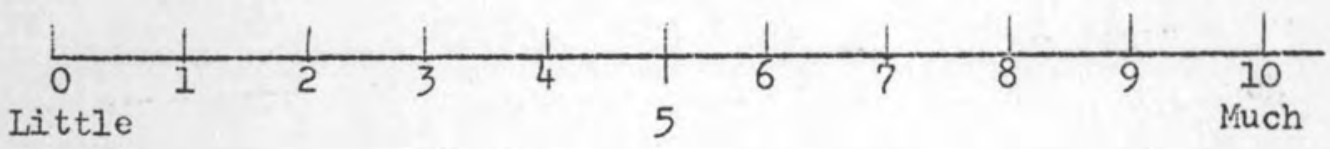

E. Other (specify

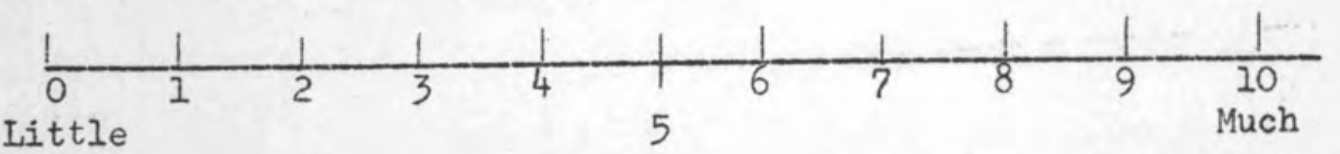

6. Interviewee shows resentment in regard to: (Rank in order of importance to interviewee)

]a. A specific individual (specify
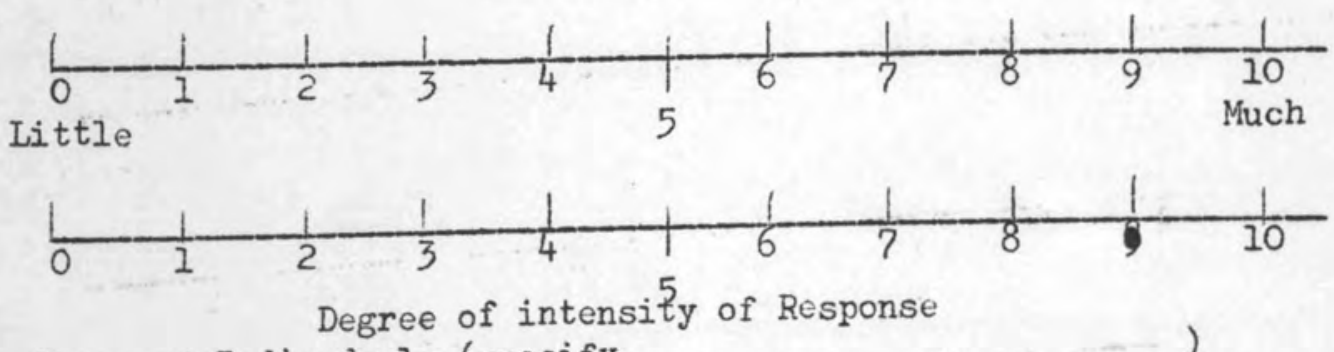

[.]b. Class of Indivuduals (specify
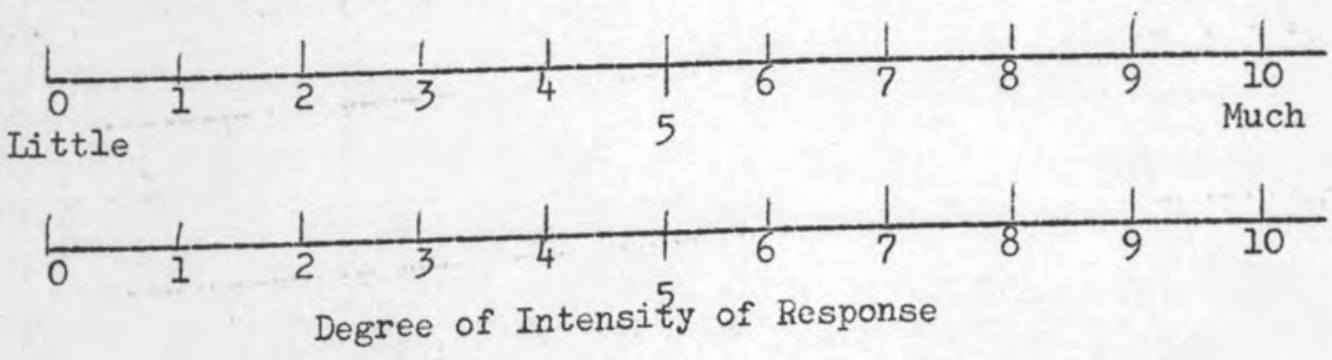
[. World in general
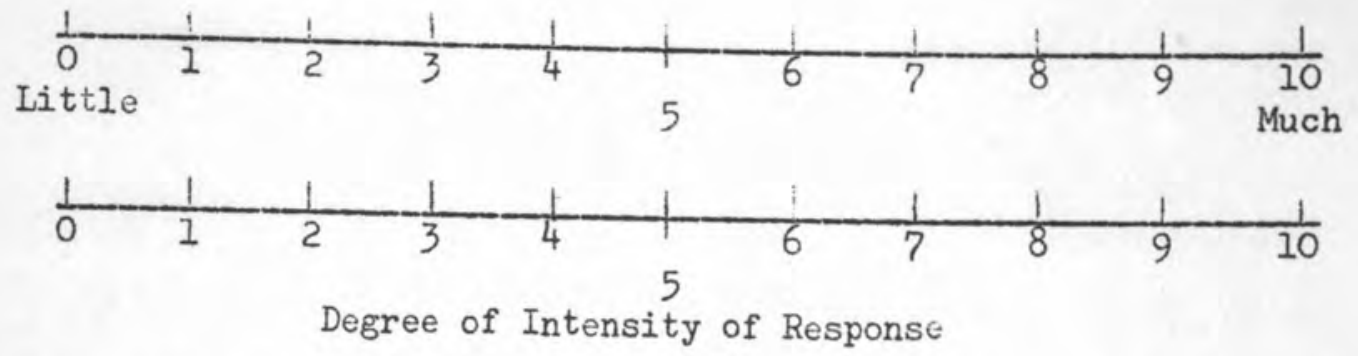

7. Who are persons mentioned as having punishment authority over interviewee? Parents Relatives (specify

Mother

Peer group persons

Father

Policcman Siblings

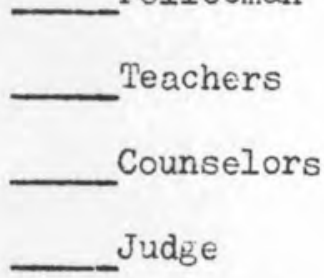
Boss Minister or Priest Other (specify

8. How does interviewee react to punishment (rank in order of importance for interviewee)

[.] a. Physical or corporal

Section 1

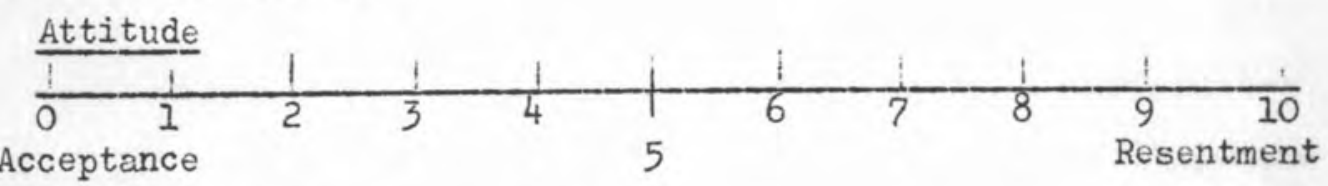

Does Interviewee think punishment is

Section 2

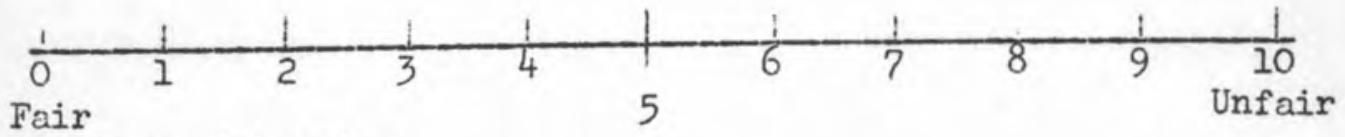

Reaction to punishment

Section 3
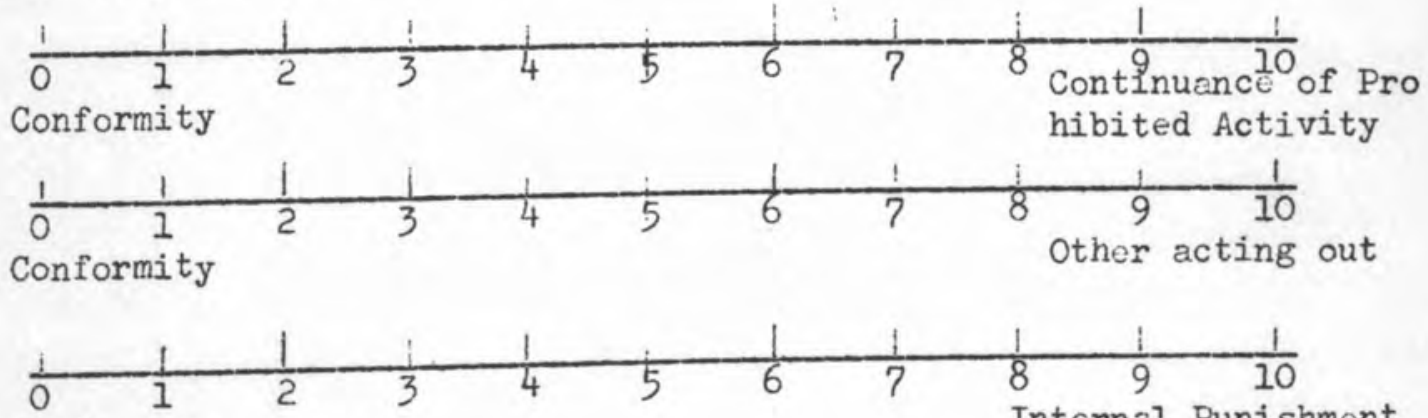

Conformity 
[1 b. Scolding

Attitude

Section 1

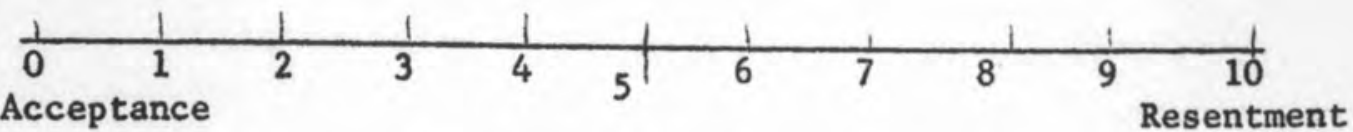

Section 2

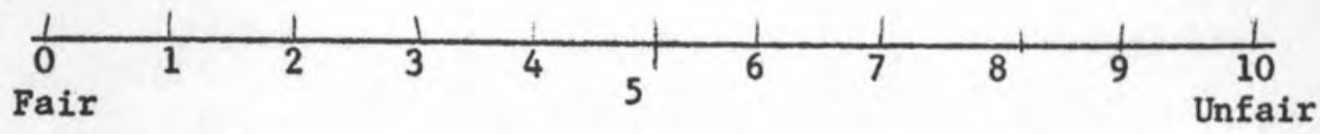

Reaction

Section 3

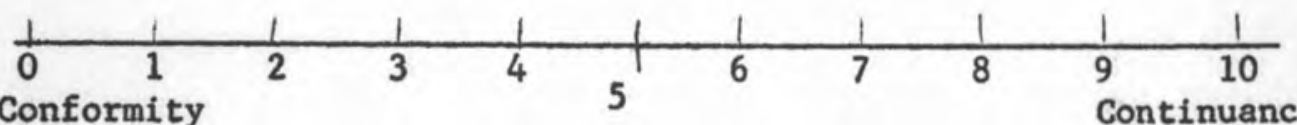

Conformity

Prohibited activity

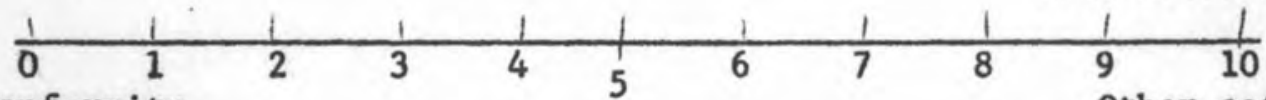

Conformity

Other acting out

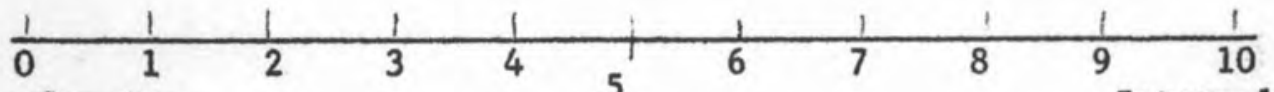

Conformity

Internal punishment

c. Being Detained (at home, school or by court)

Attitude

Section 1

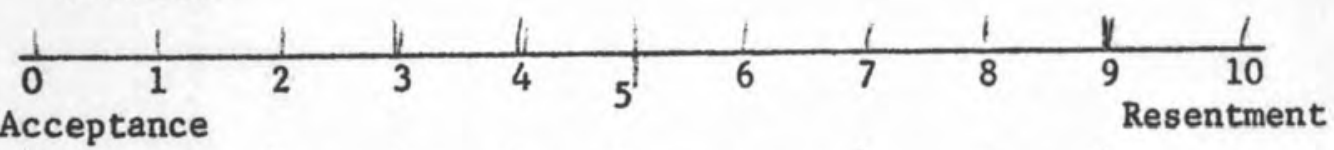

Section 2

eptance

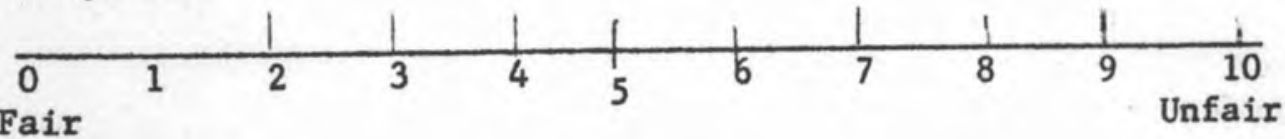

Reaction

Section 3

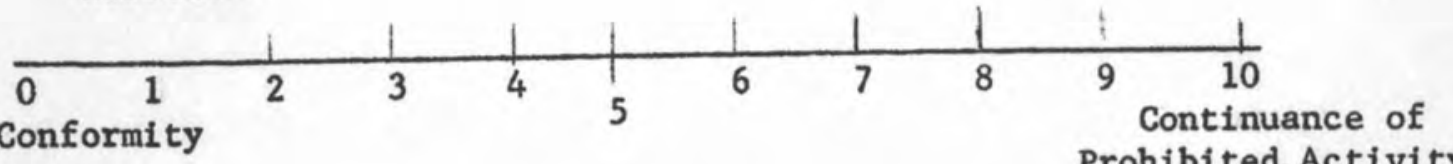
Prohibited Activity

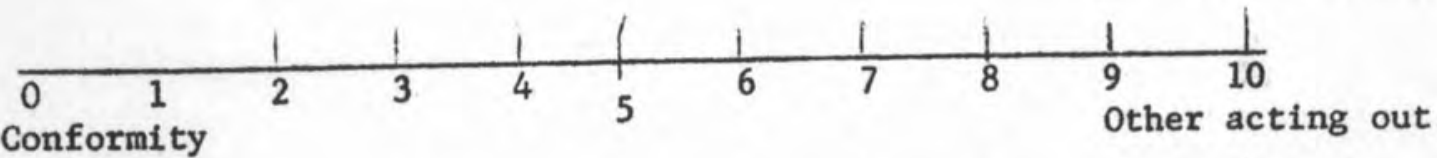

Conformity

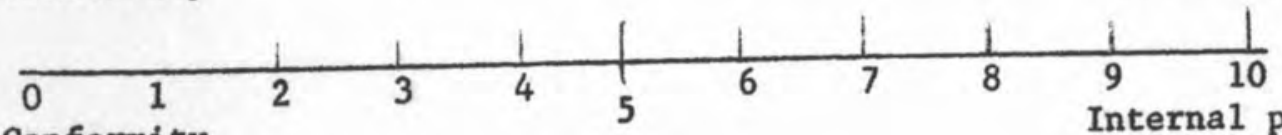

Conformity

Internal punishment

[d d. Withholding money or material goods

Attitude

Section 1

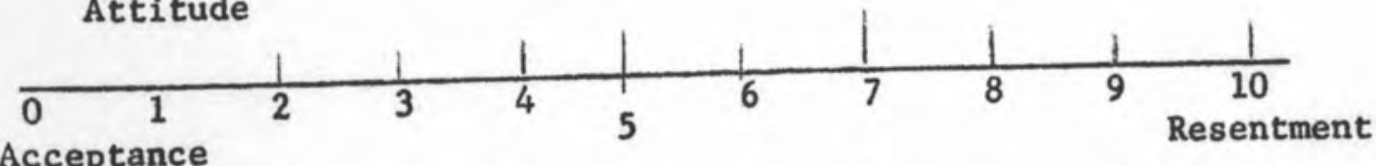

Section 2

Acceptance

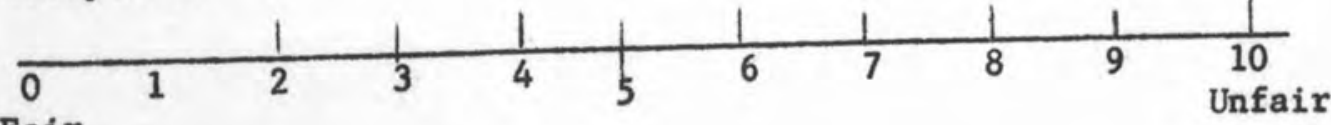

Fair 
Reaction

Section 1
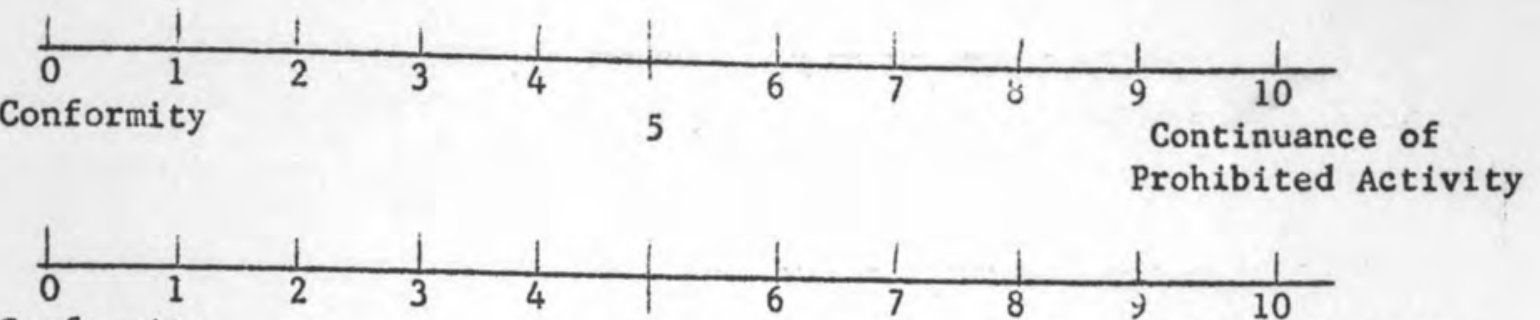

Conformity 5 Other acting out

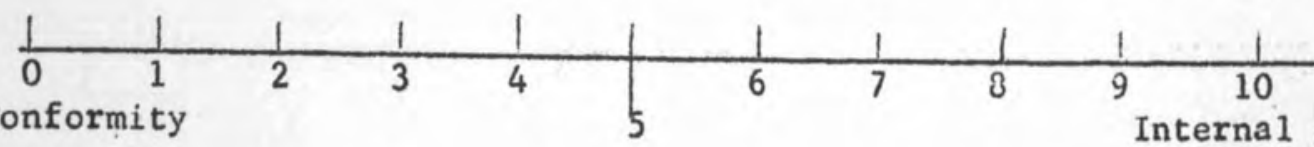

Conformity

Internal punish-

e. Withholding privileges ment

Attitude

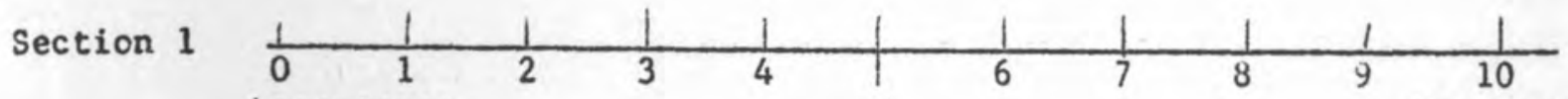

Acceptance 5 Resentment

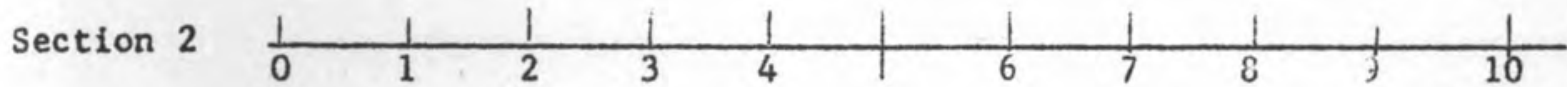

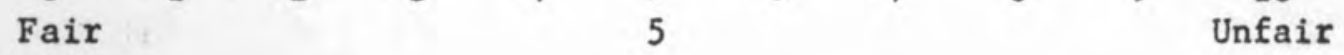

Reaction

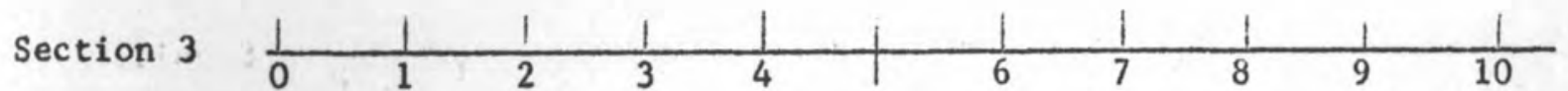

Conformity 5 Continuance of

Prohibited Activity

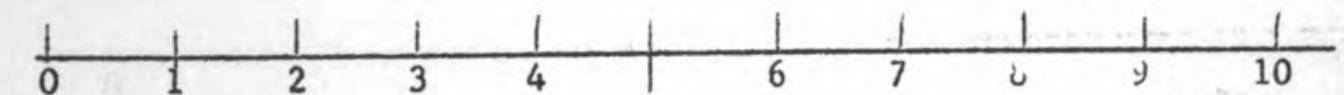

Conformity 5 other acting out

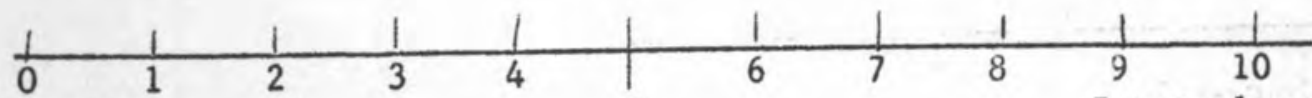
Conform Lty
5
Internal punishment

Other (specify

9. How does interviewee feel others he knows are affected by punishment?

$\square$ a. physical or corporal

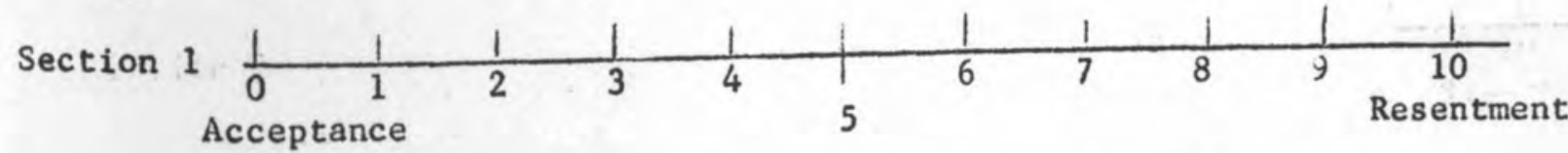

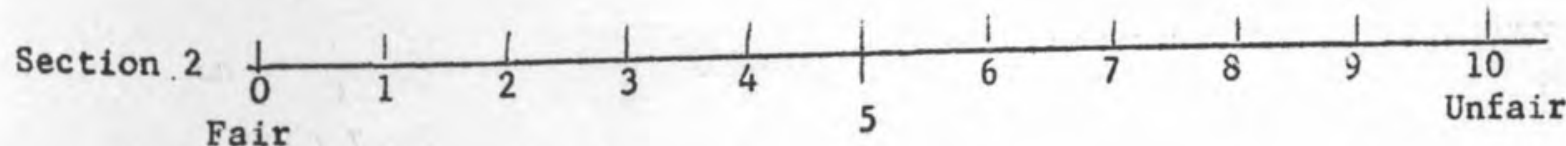

\section{Fair}

Reaction

Section 3
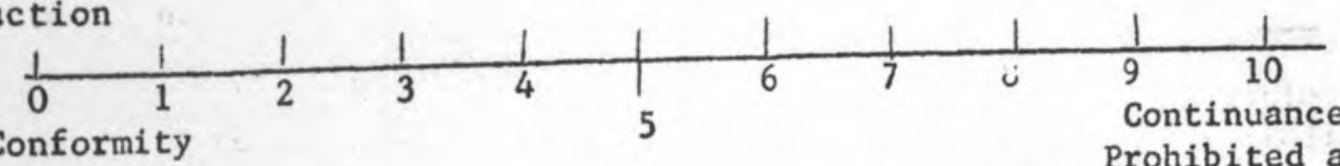

Continuance of Prohibited activity

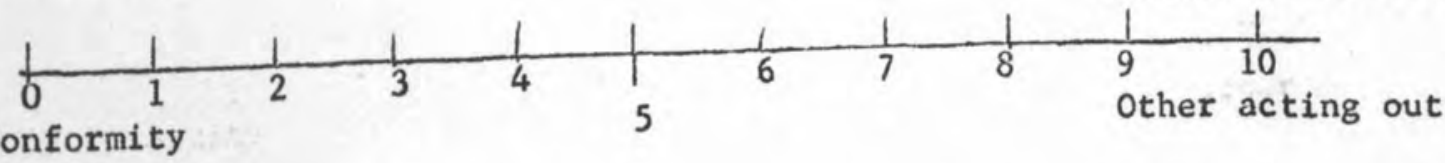




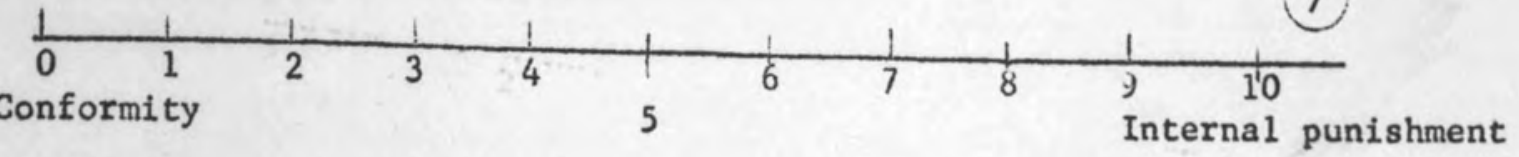

b. scolding

Section

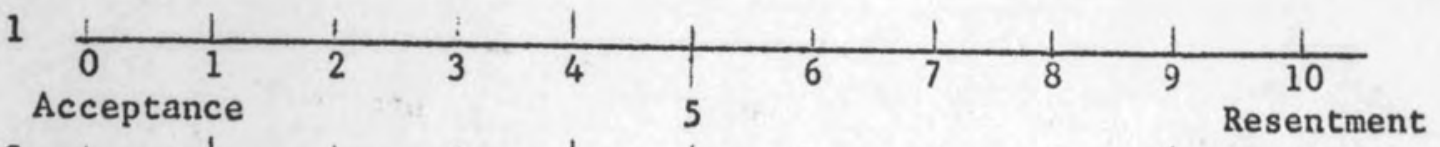

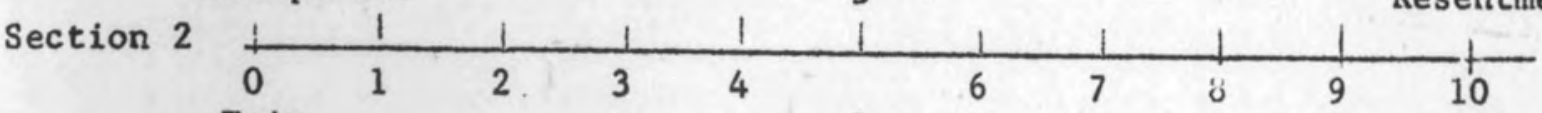

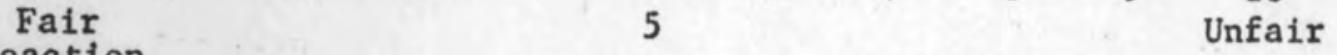

Reaction

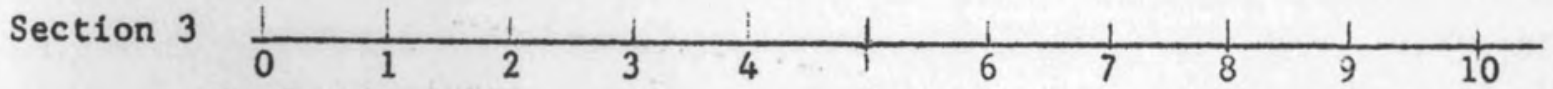

Conformity 5 Continuance of

Prohibited Activity

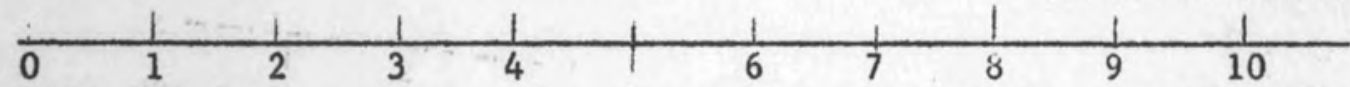

$\begin{array}{lll}\text { Conformity } & 5 & \text { Other acting out }\end{array}$

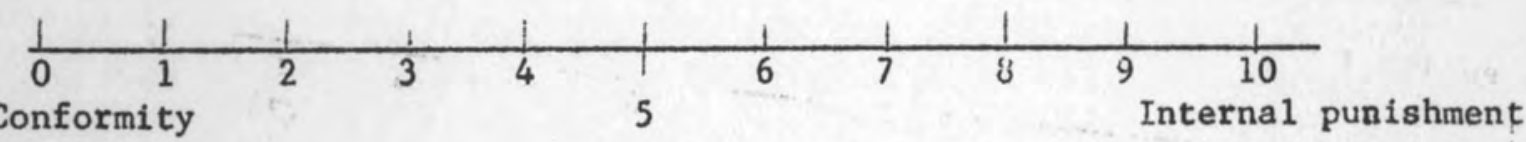

c. being detained (at home, school or at the court)

Attitude

Section 1

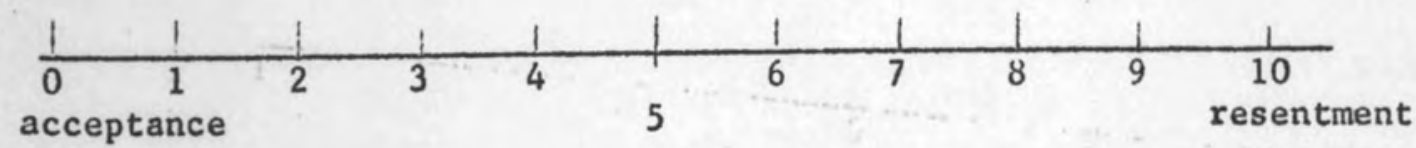

Section 2

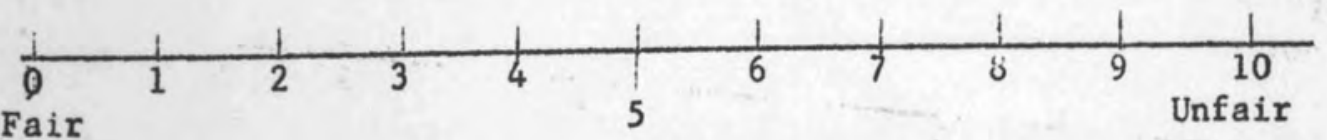

Reaction

Section 3
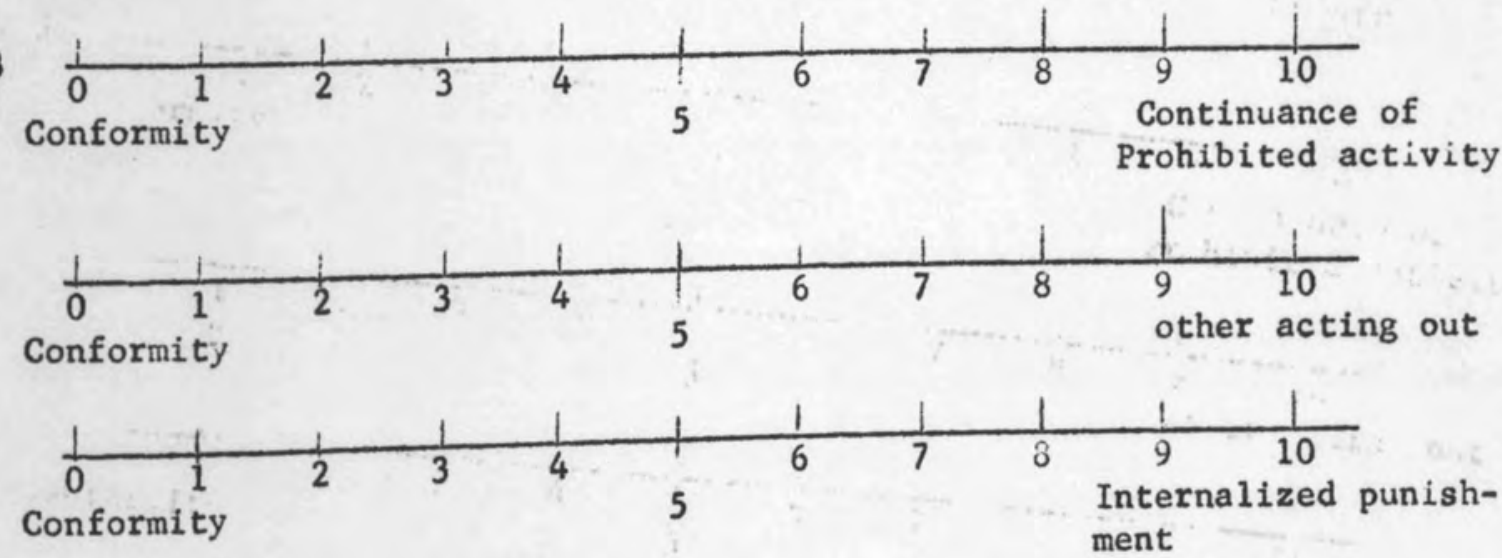
d. withholding money or material goods
attitude

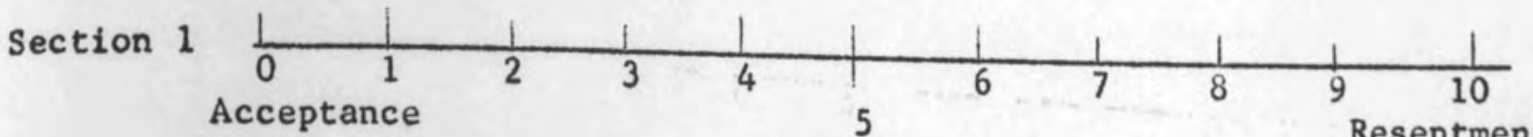

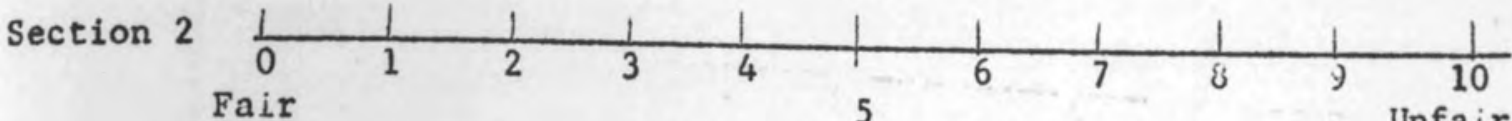

Reaction

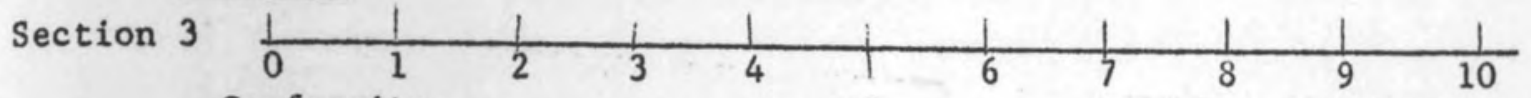

Conformity 5 Continuance of

Prohibited activity
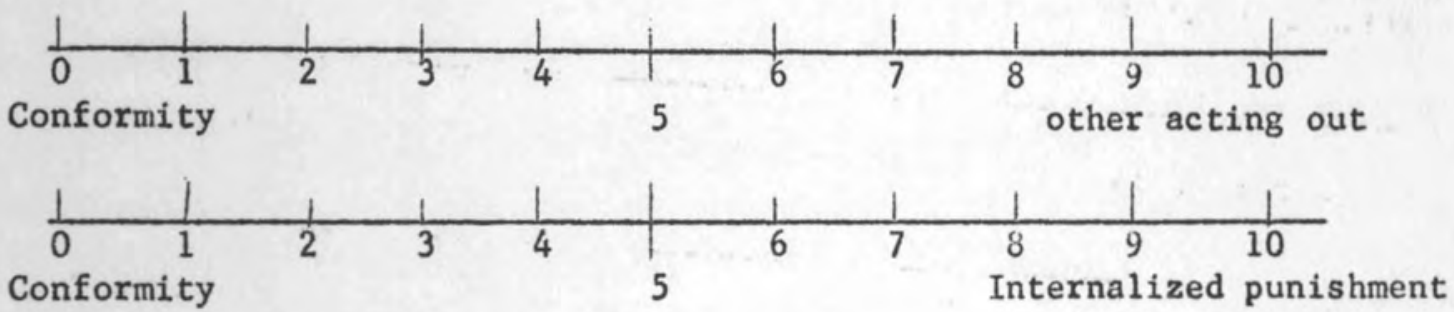

De. withholding privileges
attitude

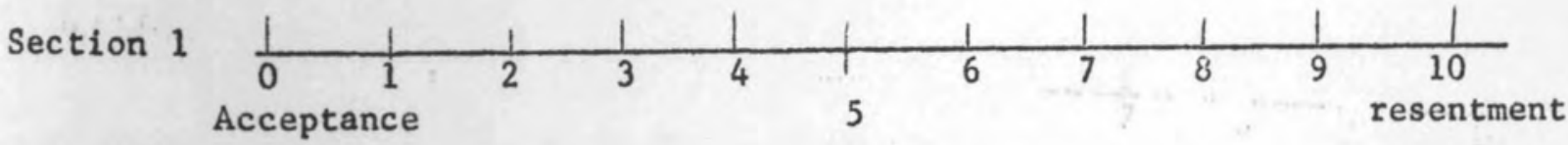

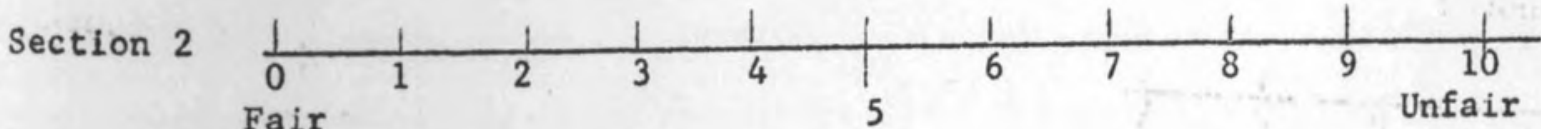

\section{Reaction}

Section 3

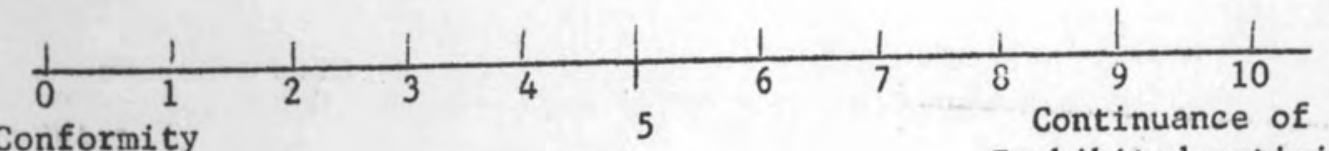

Conformity

Probibited activity
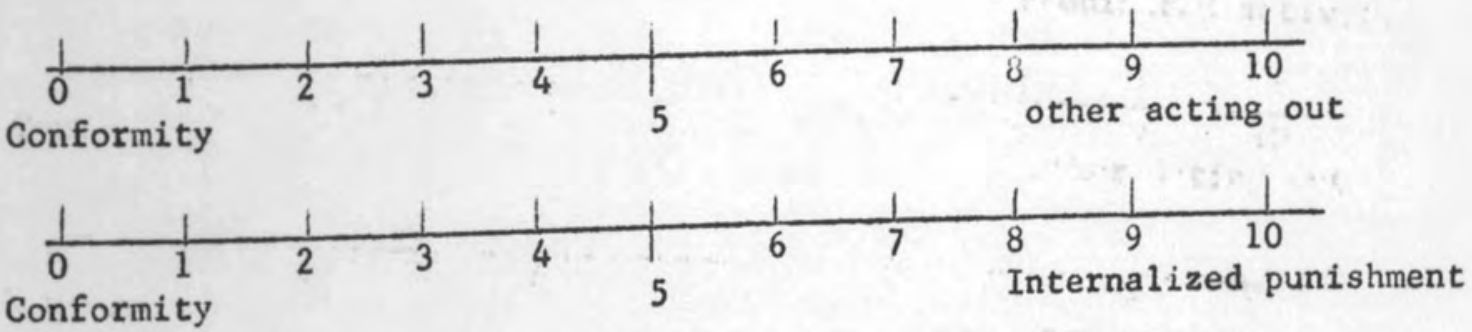

Lff. other (specify 
10. How closely identified with friends (peers) does interviewee seem?

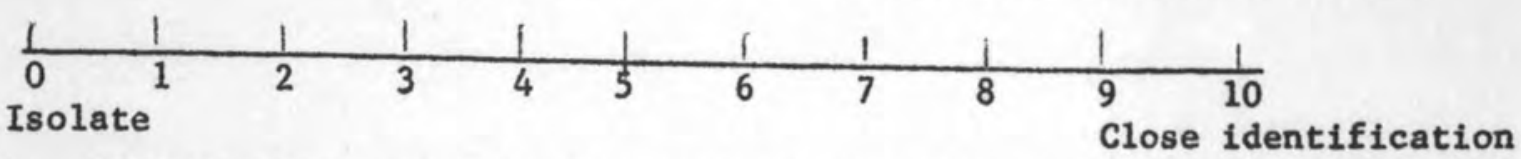

11. If interviewee were in charge of a group of boys he would: (rank in order of importance to interviewee)

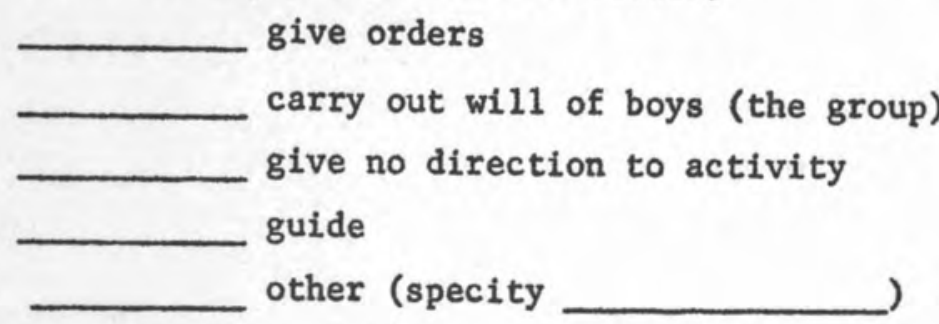

12. Interviewee would settle disputes between boys in group by: (rank)

A. Corporal punishment

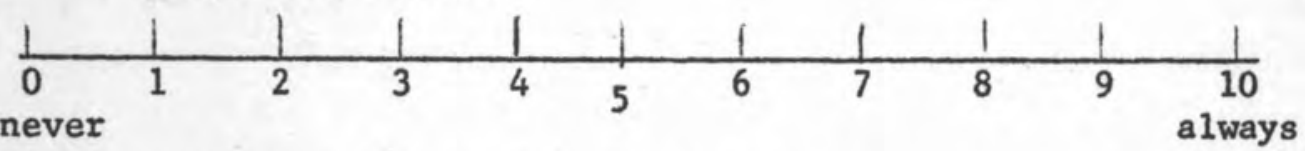

B. Isolating individuals physically

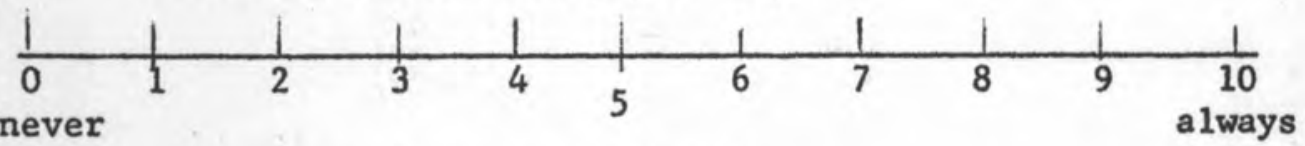

C. Isolating individuals socially

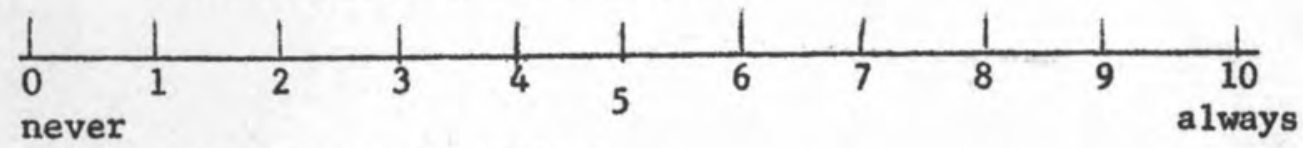

D.

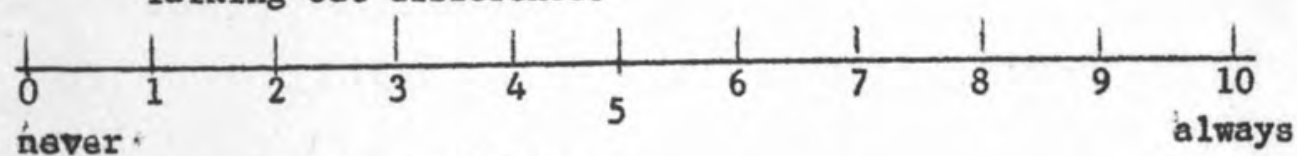

E.

$$
\text { Giving direct orders }
$$

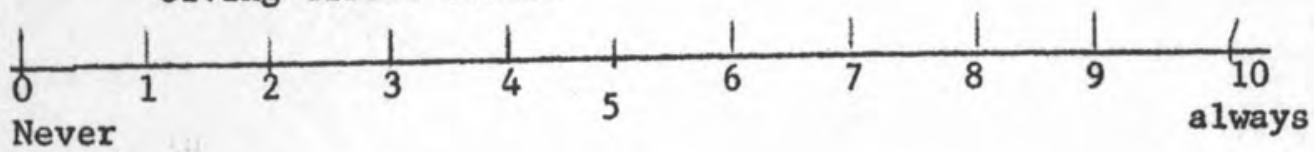

F. Doing nothing

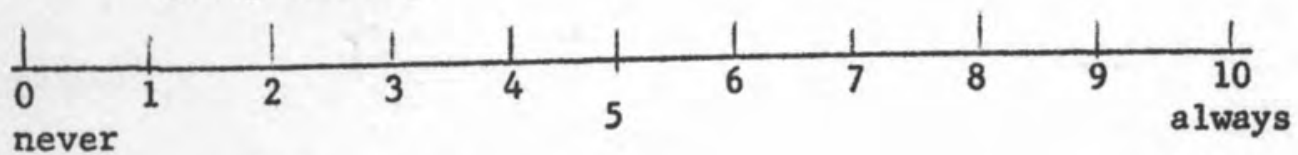

G. Withdrawing from group

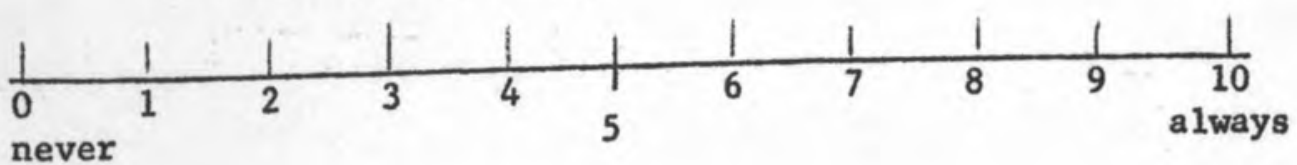


н. $\square$ Making rules

a. Alone

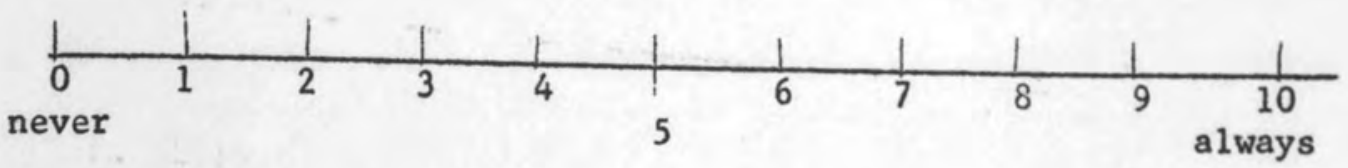

b. With group

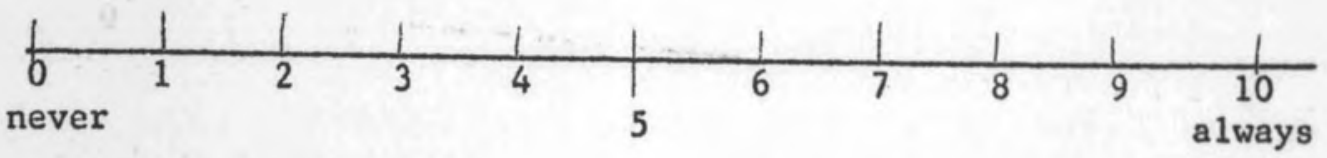

I. $\square$ Requesting help

a. from adults

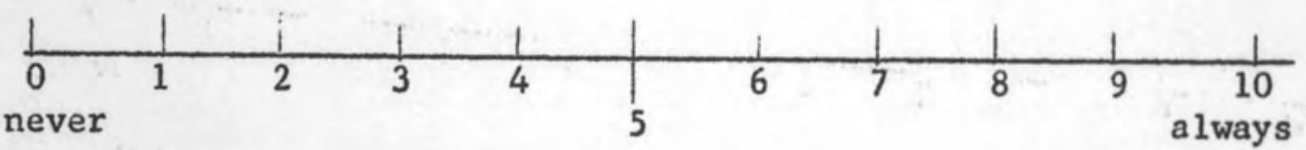

b. from group

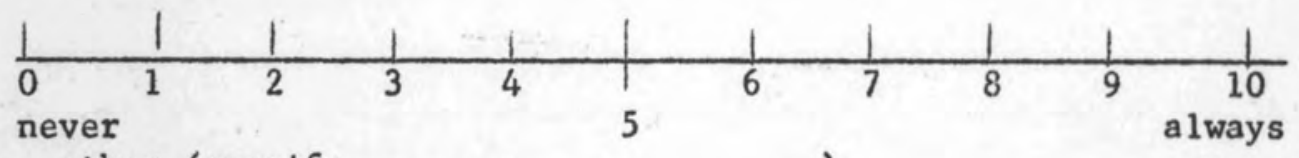

c. other (specify

13. When angry, interviewee says he (rank in order of importance to interviewee)

एa.

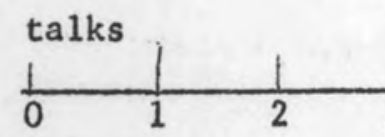

never

Lib. acts

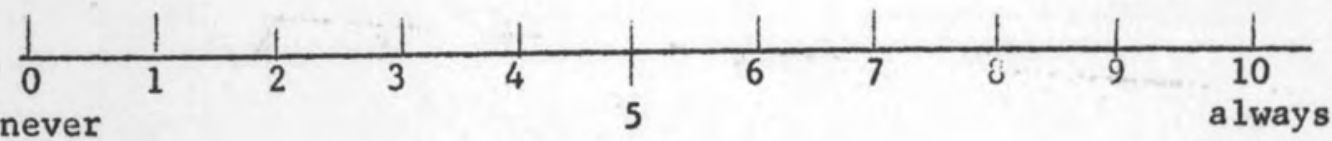

C. suppresses

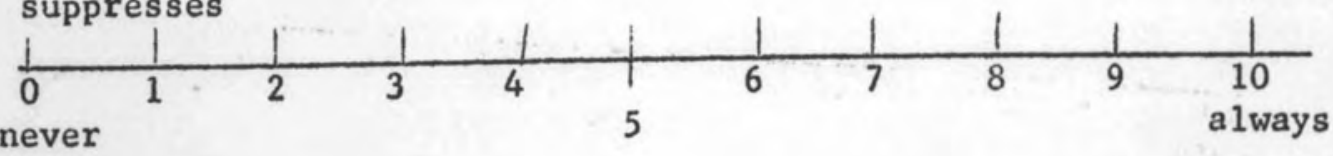

[d. sublimates

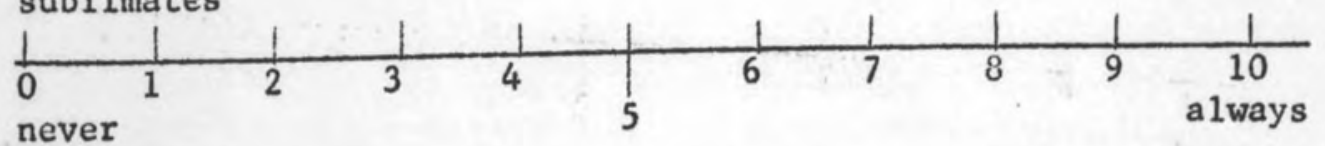

$\square$ e. other (specify

14. Observer feels when angry interviewee would (rank in order of importance to interviewee) 
Da. talk

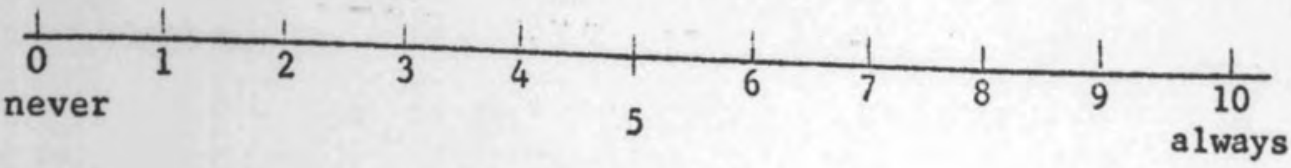

$\square$ b. act

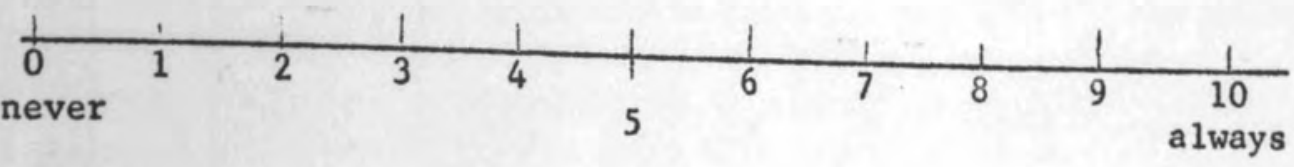

[]c. Suppress

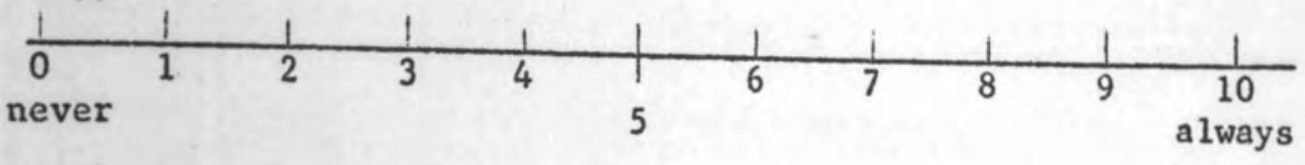

$\square$ d. sublimate

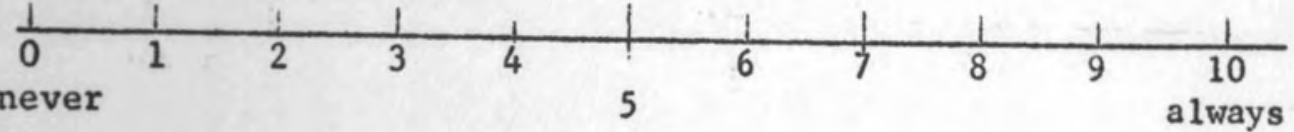

П]e. other (specify

15. How does interviewee feel about laws regarding minors

[a. curfew
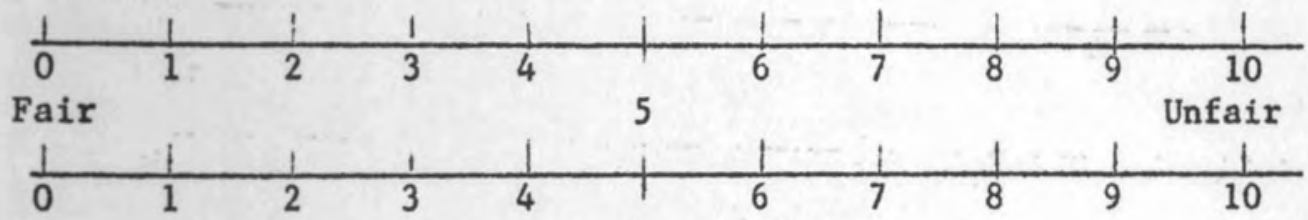

$$
5
$$

Intensity of response

[ b. smoking

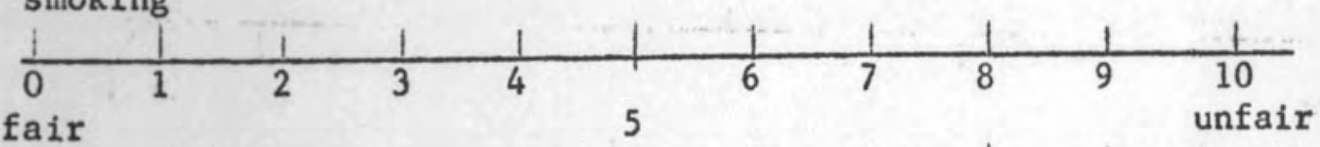

fair

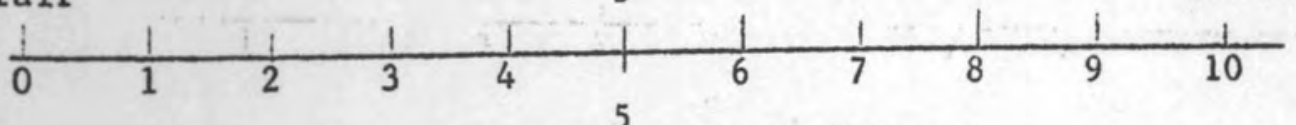

5

Intensity of response

$\square$ c. driving
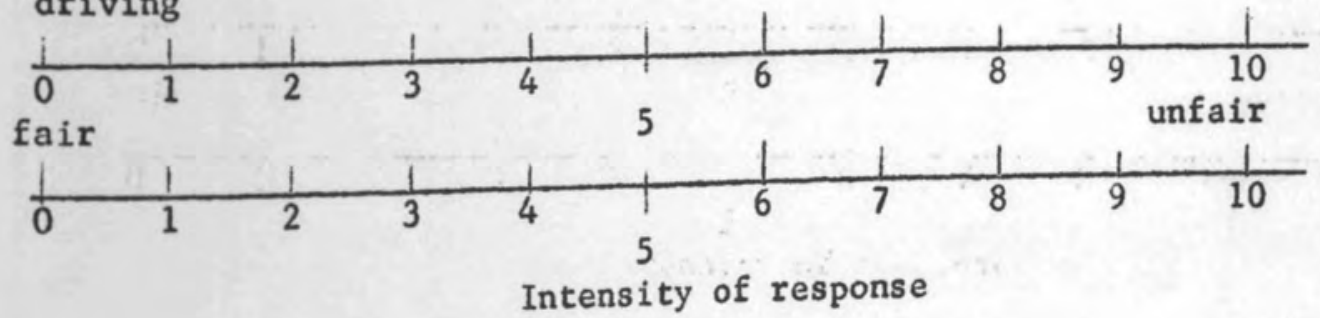

Intensity of response

[d. drinking

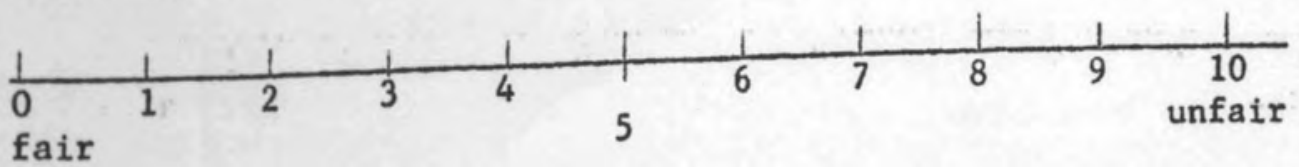




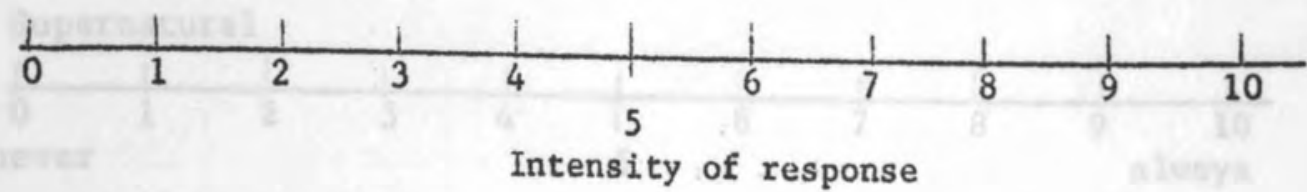

Qe. school attendance
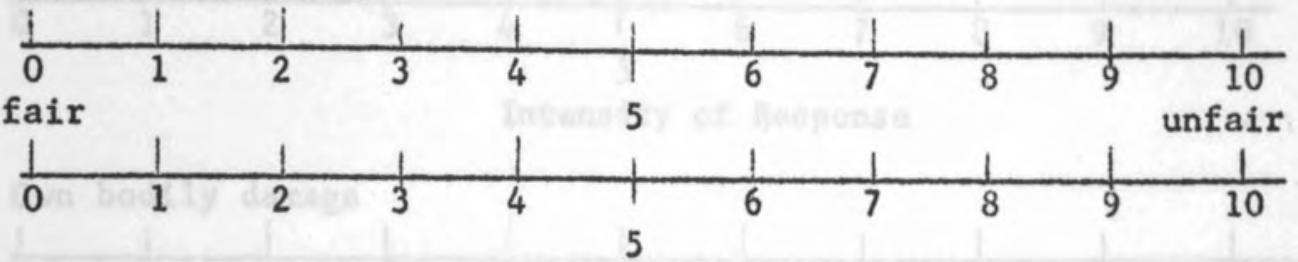

Intensity of response

Tf. other (specify

\section{FEARS}

16. Interviewee's most frightening experience put in terms of: (rank in order of importance to interviewee)

$\square$ a. People (social environment)

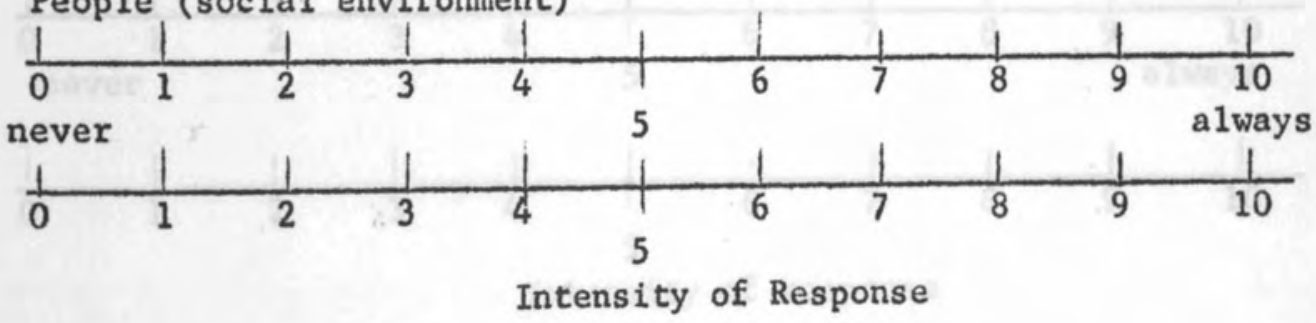

[b. Natural phenomena

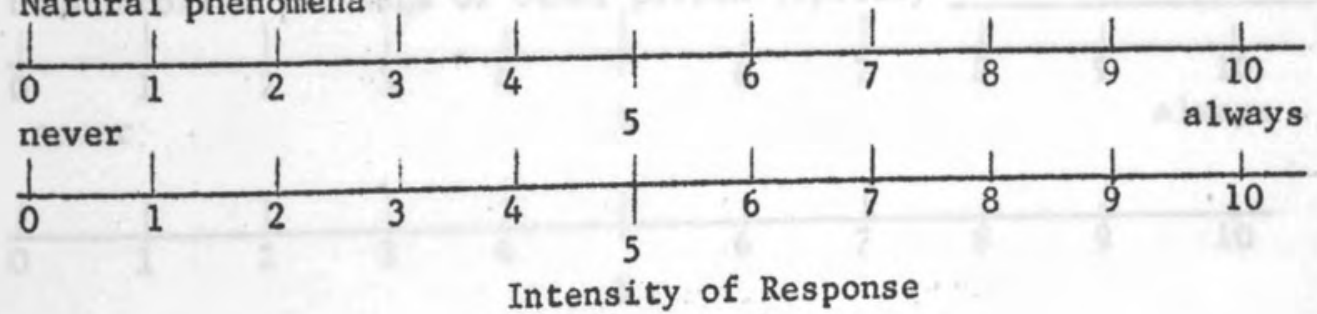

Tc. Man made Environment
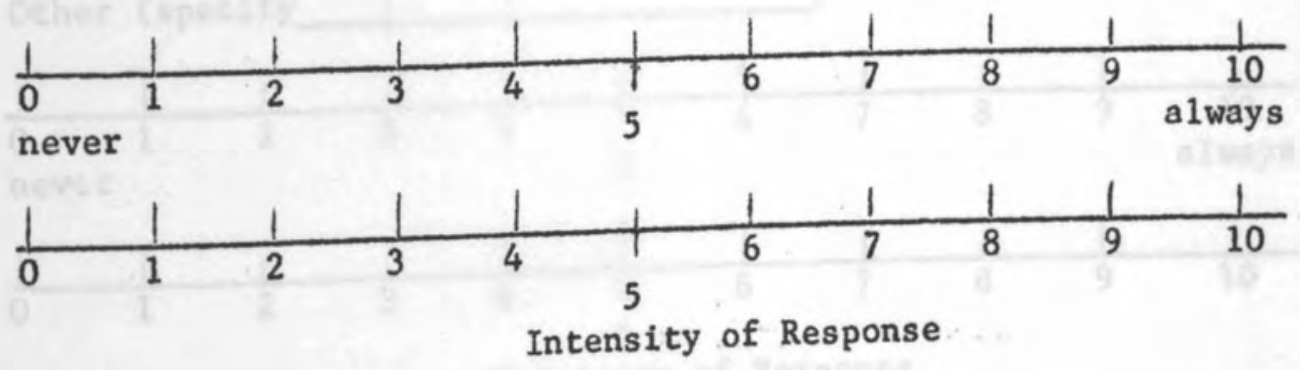
$\square$ d. Supernatural
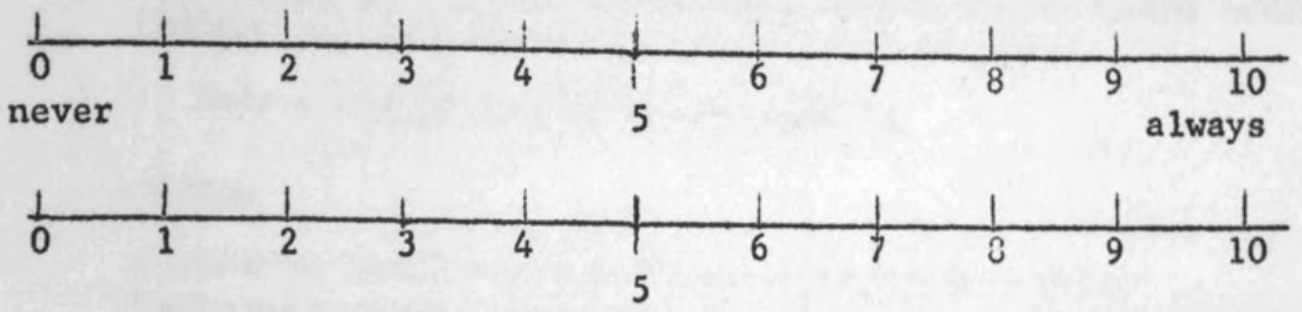

Intensity of Response

[e. Own bodily damage
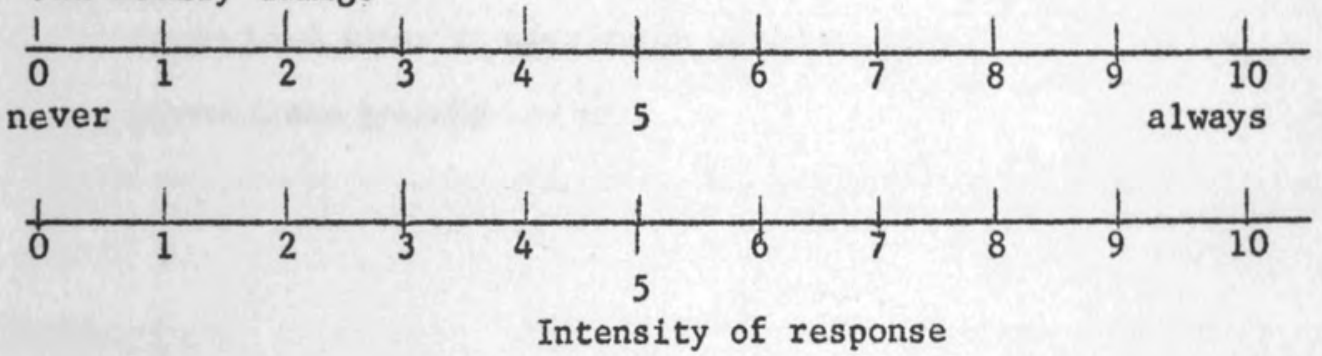

$\square$ f. Own uncontrolled feelings
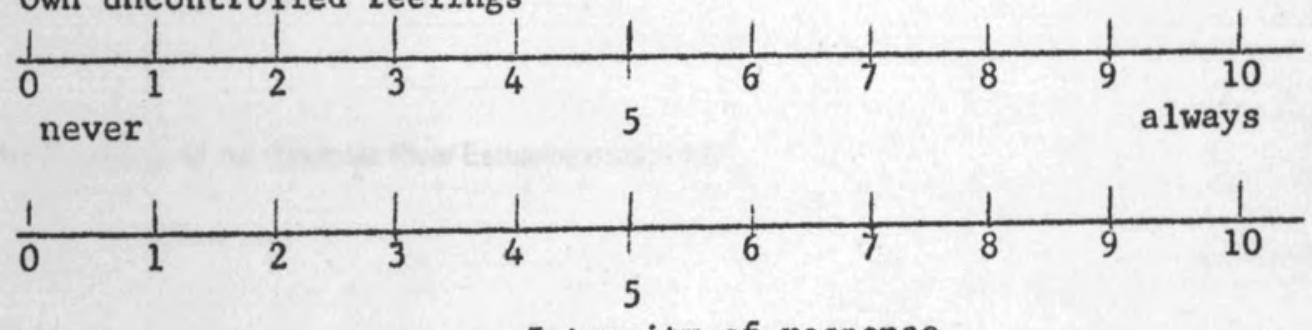

Intensity of response

पg. Uncontrolled feelings of other person (specify
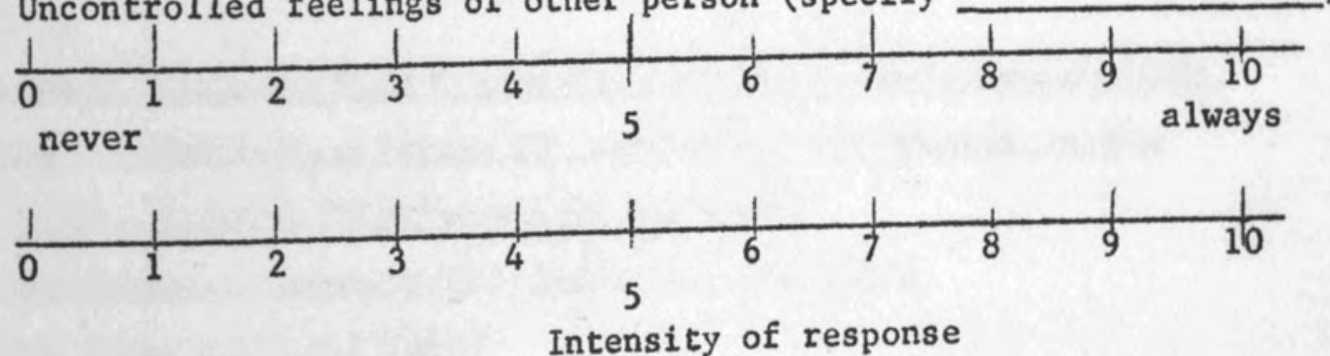

$\square$ h. Other (specify
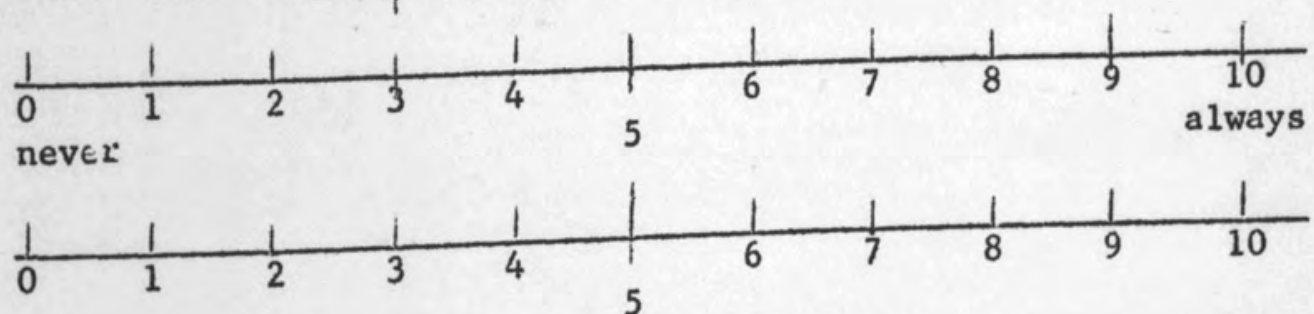

Intensity of Response 
17. Interviewee feels other boys are afraid of (rank in order of importance
to interviewee)

Пa. People (social environment)

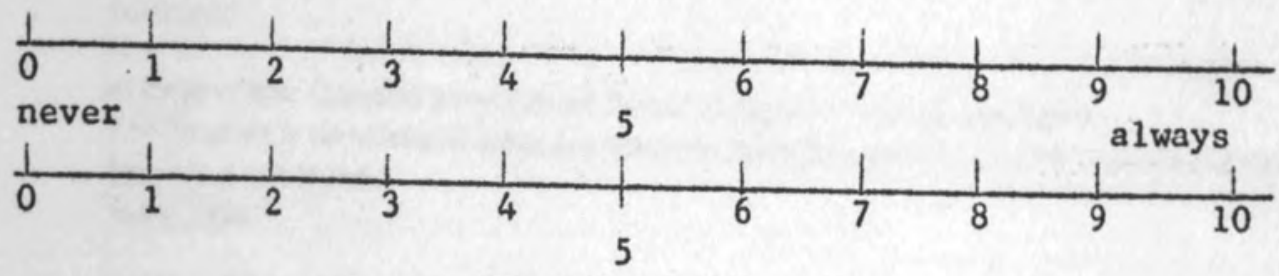

Intensity of Response

-. b. Natural phenomena
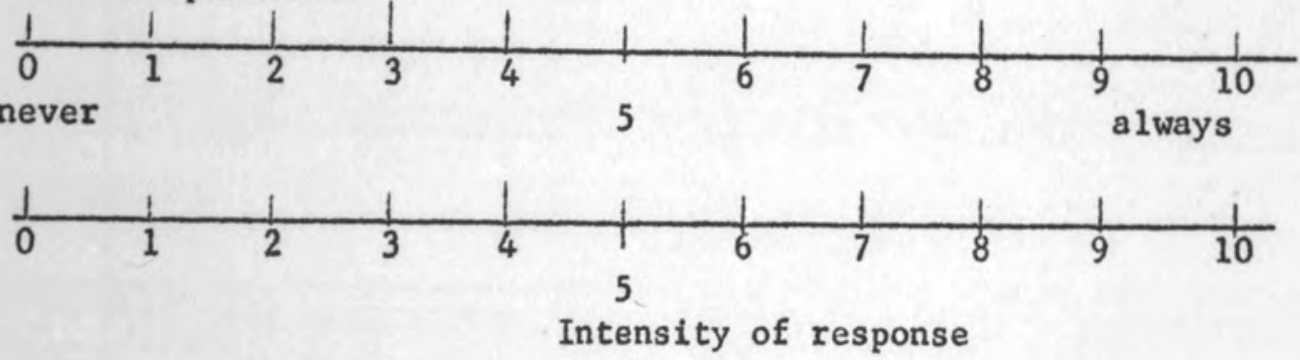

Dc. Man made environment
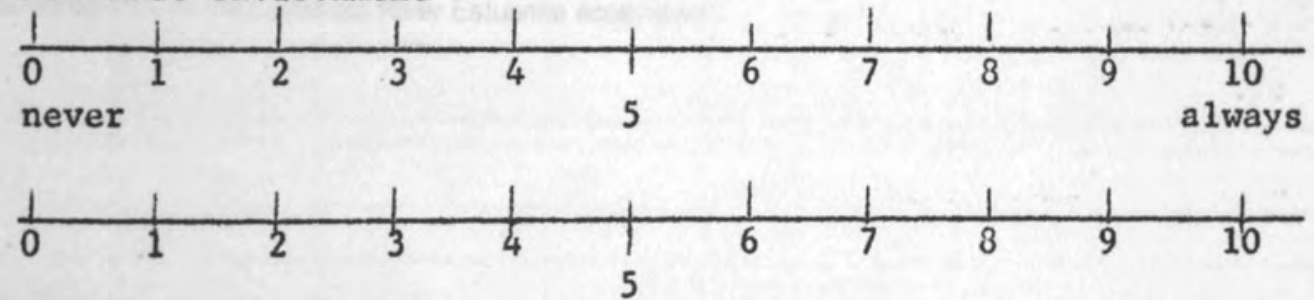

Intensity of response

पd. Supernatural
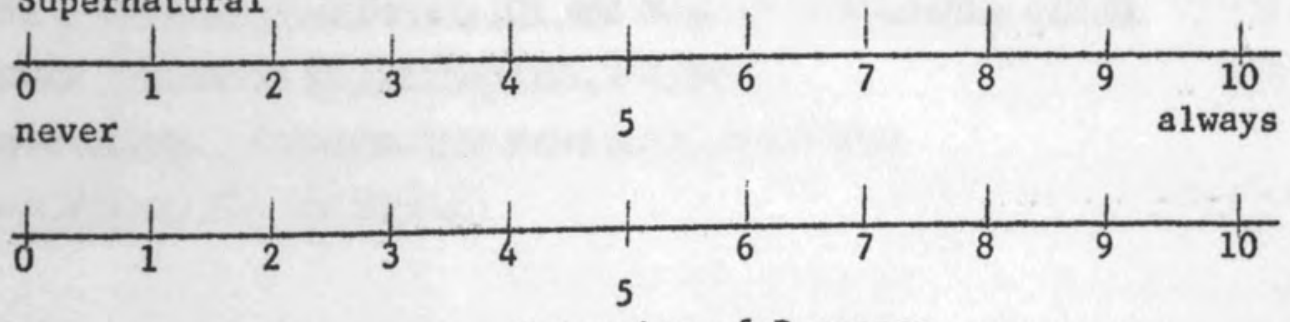

Intensity of Response

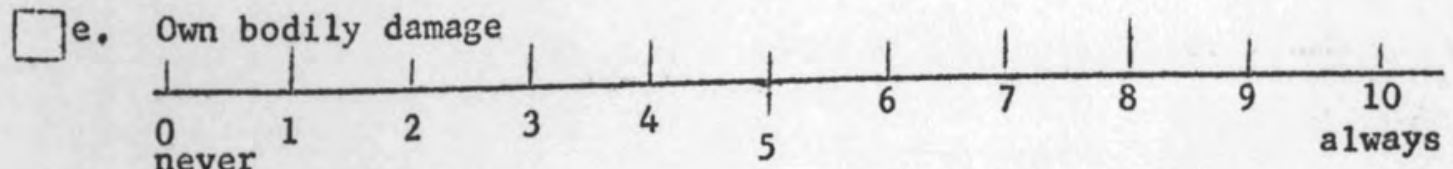

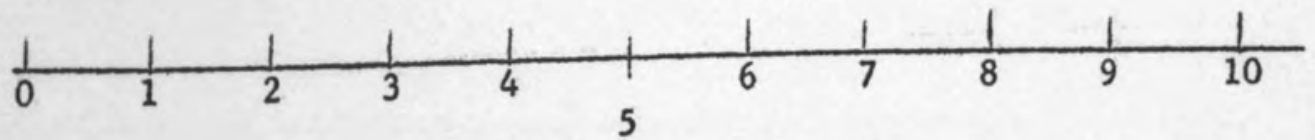

Intensity of Response 
$\square$ f. Own uncontolled feelings
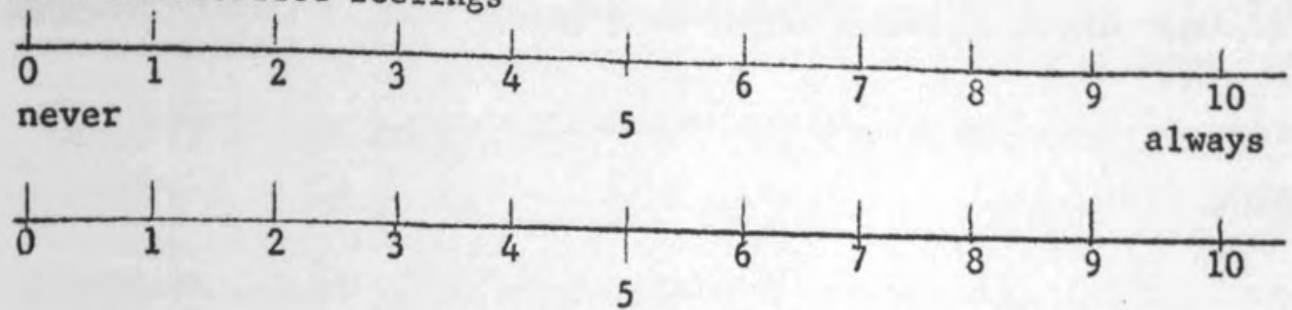

Intensity of Response

$\square$ g. Uncontrolled feelings of other person (specify
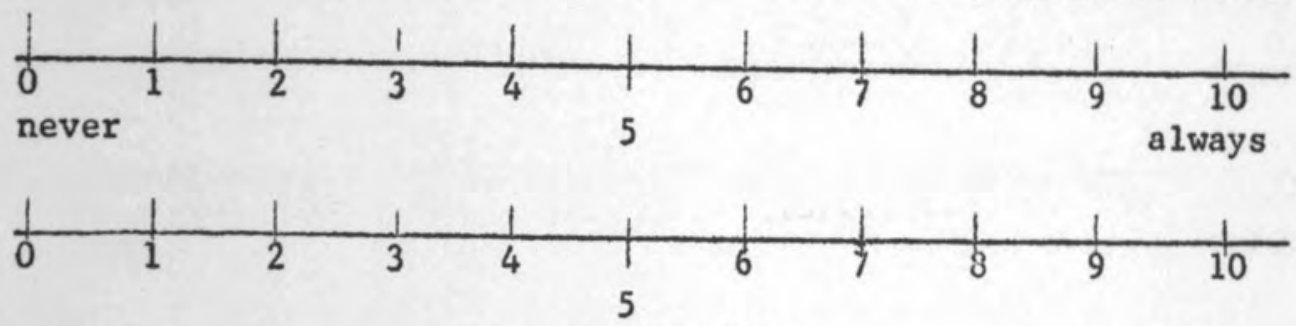

Intensity of Response

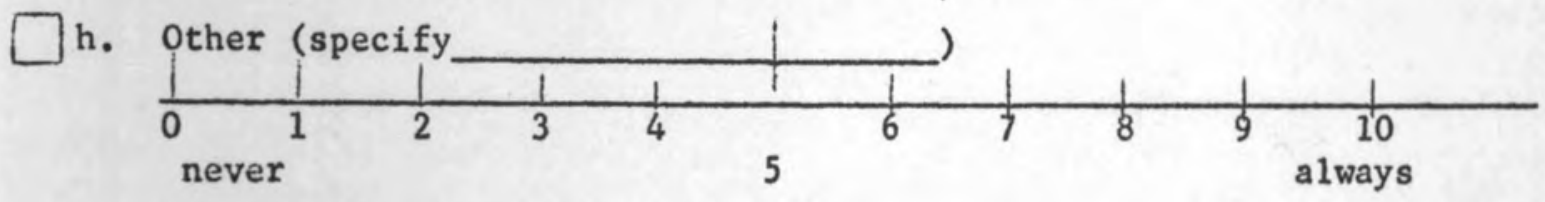

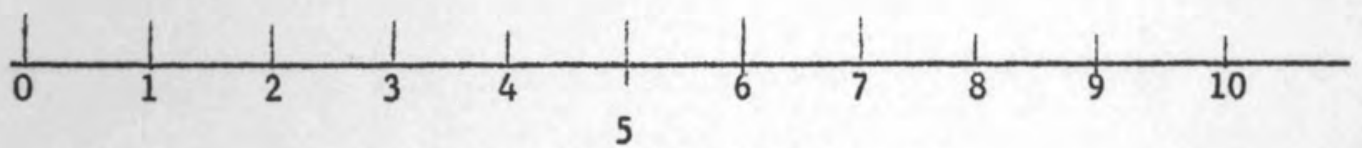

Intensity of Response

18. How important does Interviewee think possession of money is?
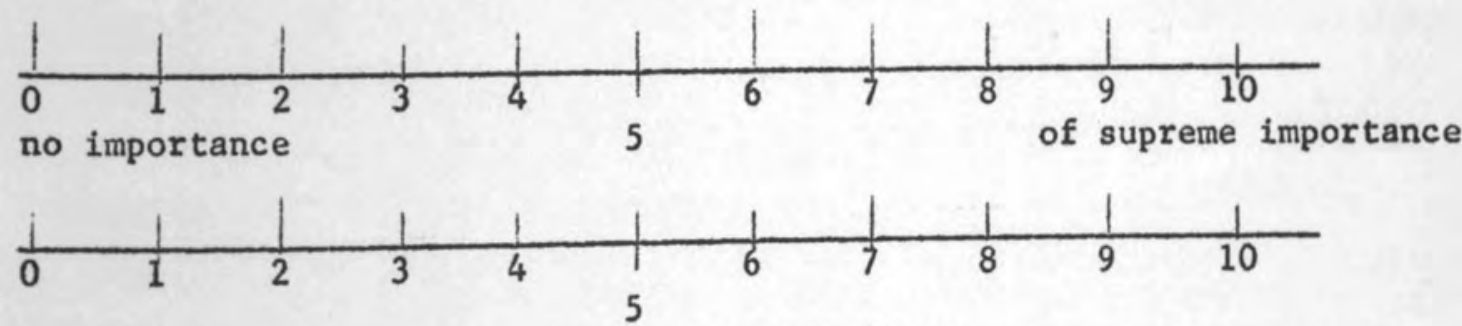

Intensity of Response

19. How common does interviewee think loneliness is?

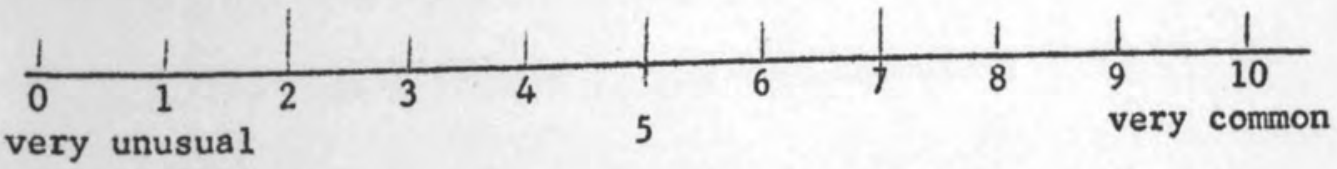

20. Degree of fearfulness whown by interviewee to interview situation

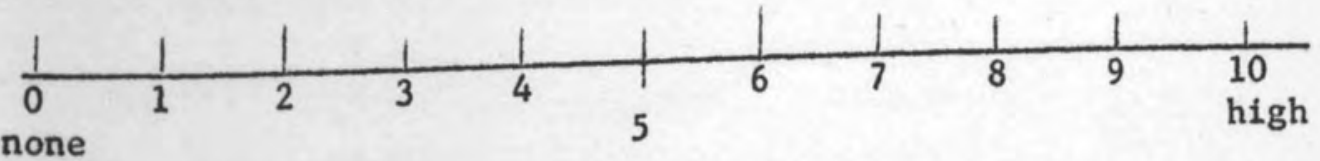


21. Interviewee sees himself in later years in terms of Personality traits (rank in order of importance to interviewee)

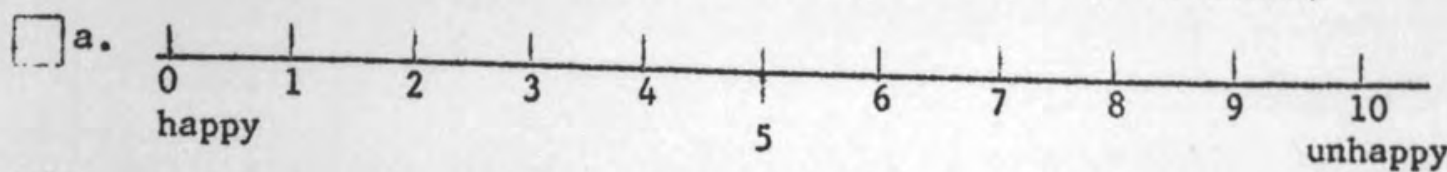

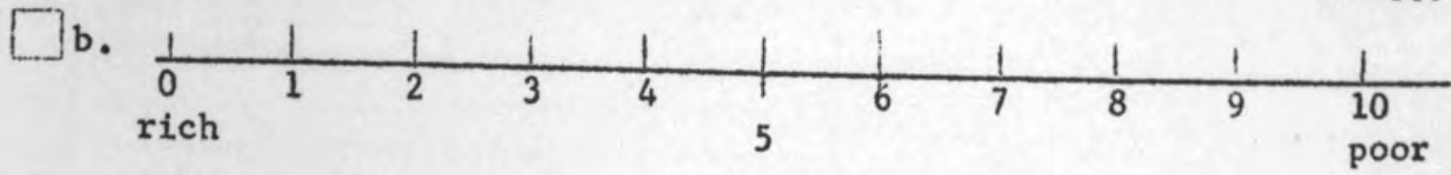

[c. \begin{tabular}{lllll|llll}
1 & 1 & 1 & $\frac{1}{1}$ & $\frac{1}{4}$ & $\frac{1}{1}$ & 1 \\
\hline 0 & 1 & 2 & 3 & 4 & 6 & 7 & 8 & 9
\end{tabular} $\begin{array}{lll}\text { successful } & 5 & \text { unsuccessful }\end{array}$

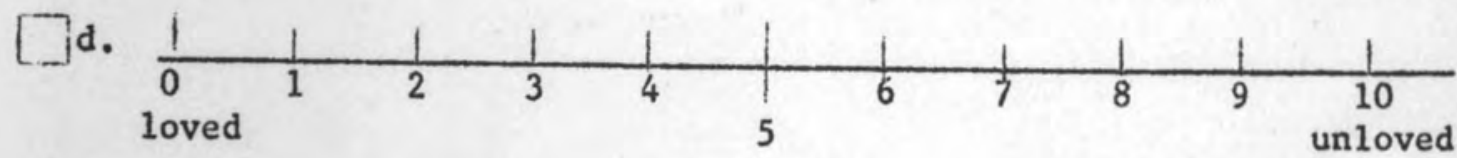
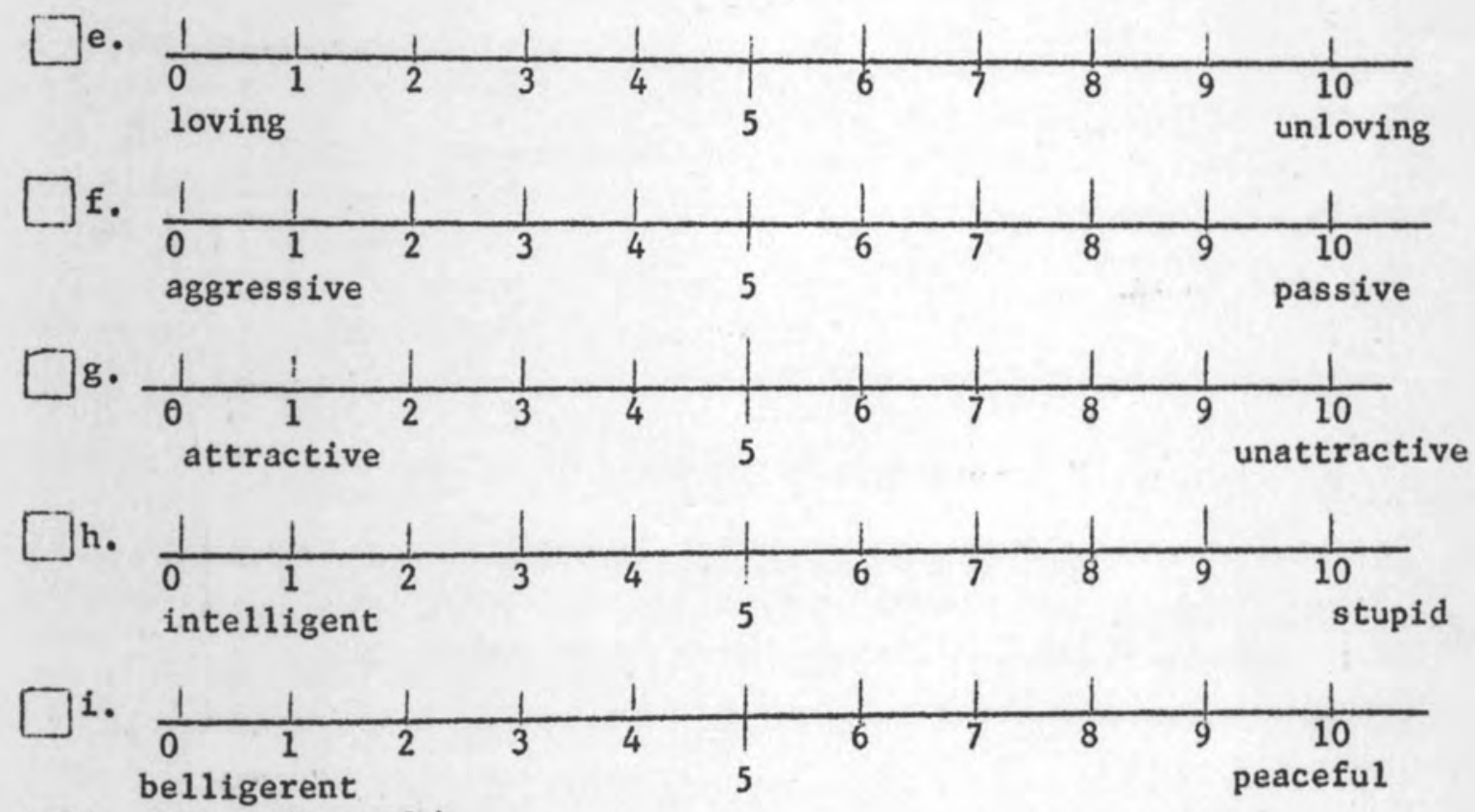

$\square^{j}$. Other (specify)

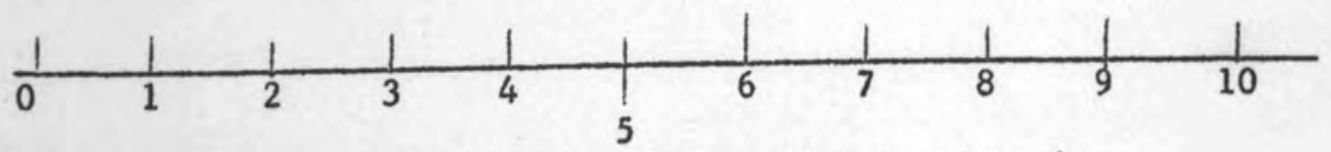

21A. Future roles (rank in order of importance to interviewee)

[a. occupational (specify

$\square$ b. family roles (specify

[c. future school

$\square$ d. military service

$\square$ e. other (specify 
22. Do interviewee's aspirations seem realistic?

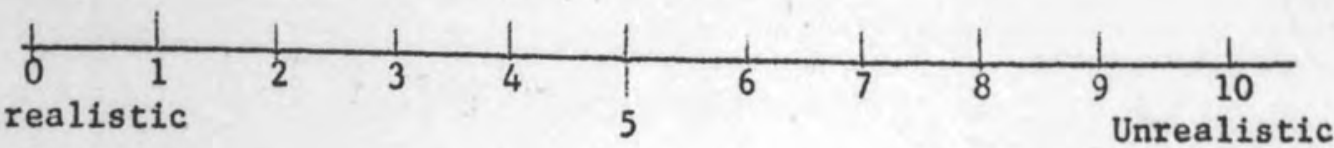

23. Does interviewee see desired goal of kind of person he wants to be as attainable?

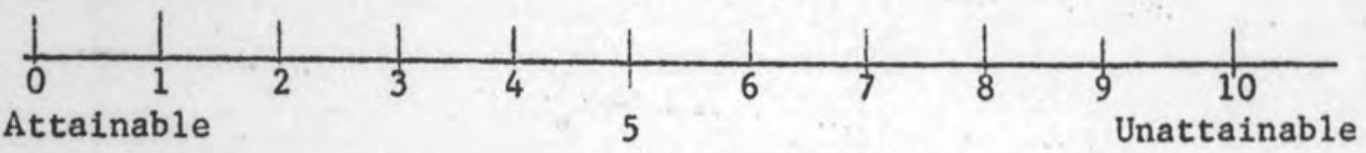

24. Does interviewee see occupational goals as attainable?

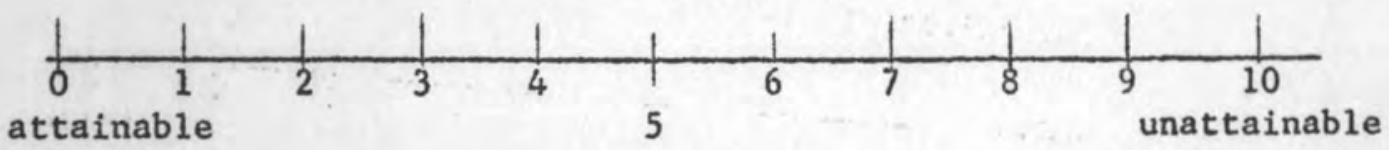

25. Interviewee's ideas of future roles shows identification with (rank in order of importance to interviewee)
A. $\square$ mother
B. $\square$ father
C. $\square$ both parents
D. $\square$ peers
E. Tsiblings
F. fantasy figures (specify)
G. $\square$ famous real people (specify
H. $\square$ other adult figures (specify
I. $\square$ no identifications
J. $\square$ other identification (specify

26. Does interviewee see himself as being in harmony with society or out of kilter. with society?

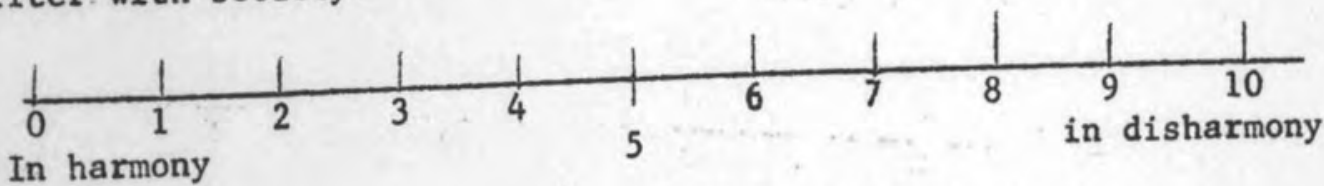

27. Does interviewee see his goals as changing through time?

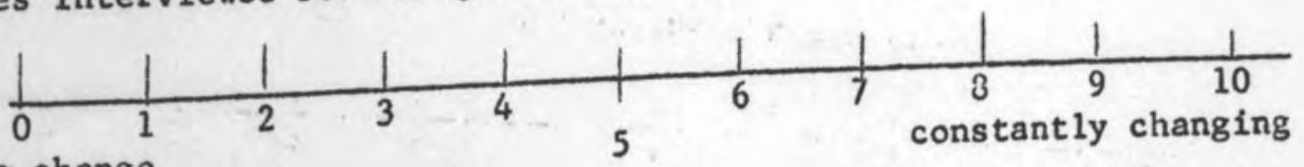
no change 
28. Does interviewee appear to have thought about the future?

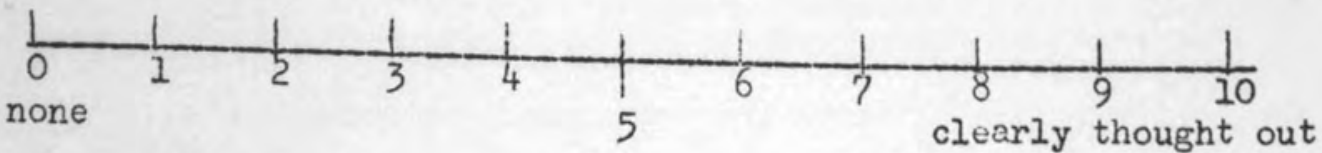

29. Does interviewee think other adolescents have thought about the future?

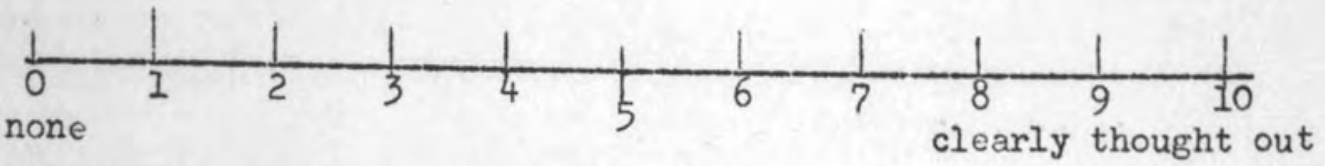

30. Does interviewee think other kids generally know wh t they want?

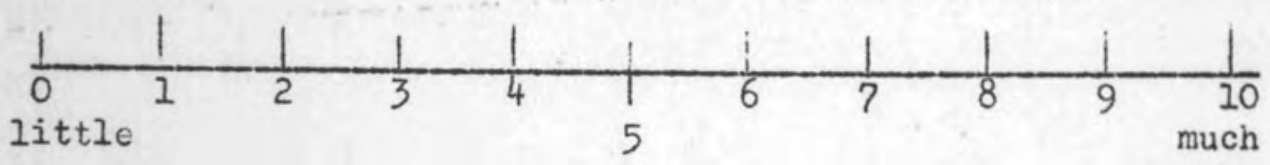

31. Does interviewee think most people know what they want?

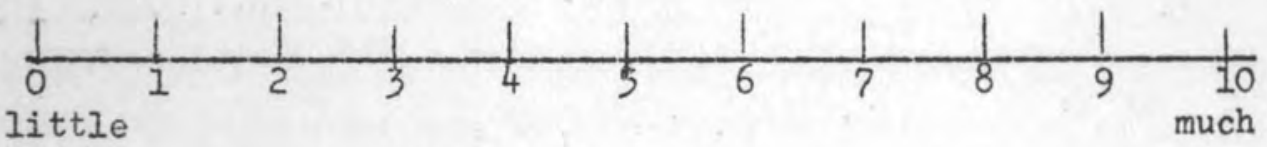

32. If interviewee could be anything he wanted he would be: (rank in order of importance to interviewee)

$\square$ a. specific person (specify

$\square$ b. type of personality (specify

$\square$ c. occupational type (specify

$\square$ d. family person (specify

$\square$ e. other (specify

WHAT DELINGUENTS FEEL THEY HAVE TO OVLRCOME

33. What bothers interviewee about himself? (rank in order of importance to interviewee)

a. physical appearance

[.]b. mental limitations

$\square$ c. physical prowess

$\square$ d. personal appearance (grooming)

П]e. self-consciousness 
Qf. shyness or retiring personality

[]g. uncontrolled aggressiveng̈ss

[]h. nervousness

$\square$ i. lack of self-confidence

$\square$ j. doubts of self worth

पk. lack of physical resources

[1. other (specify

34. Do interviewee's problems to overcome seem realistic?

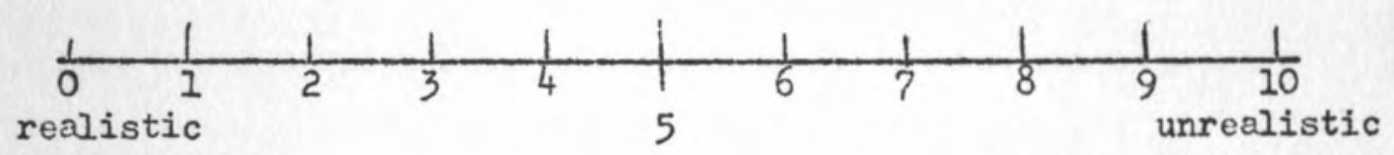

35. What does interviewee think bothers other adolescents about themselves? (rank in order of importance to interviewee)

$\square$ a. physical appearance

$\square$ b. mental limitations

$\square$ c. physical prowess

$\square$ d. personal appearance (grooming)

$\square$ e. self-consciousness

$\square$ f. shyness or retiring personality

$\square$ g. uncontrolled ags ressiveness

$\square$ h. nervousness

$\square$ i. lack of self confidence

$\square j$. doubts of self worth

$\square$ k. lack of physical resources

$\square 1$. other (specify 
36. Interviewee feels the most difficult thing about getting along in the world is due to: (rank in order of importance to interviojwee)

Da. own physical defects

$\square$ b. own mental defects

$\square$ c. own emotional defects

$\square$ d. other people's defects (specify

एe. unfairness in human relations (specify area

$\square$ f. lack of material means

प8. other (specify

पh. none

37. Interviewee sees future difficulties in terms of : (rank in order of importance to interviewee)

[a. own physical defects

[b. own mental defects

$\square$ c. own emotional defects

$\square$ d. other ceople's defects (specify

$\square$ e. unfairness in human relations (specify area

$\square$ f. lack of material means

$\square$. other (specify

Đh. none

38. What faults does interviewee think other people notice in him? (rank in order of importance to interviewee.)

$\square$ a. physical appearance

Db. mental limitations

[c. physical prowess

Пd. personal appearance (grooming)

[]e. self-consciousness

$\square$ f. shyness or rctiring personality 
$\square$ g. uncontrolled aggressiveness

$\square$ h. nervousness

$\square$ i. lack of self-confidence

$\square j$. doubts of self-worth

$\square \mathrm{k}$. lack of physical resources

$\square$ 1. other (specify

39. Does interviewee think he can chonge the faults he sees in himself?

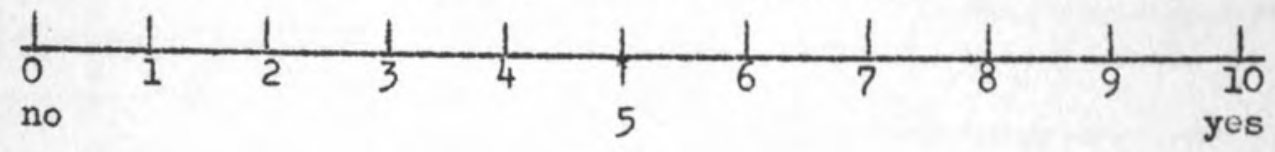

40. Does interviewee think he can change faults seen in him by others?

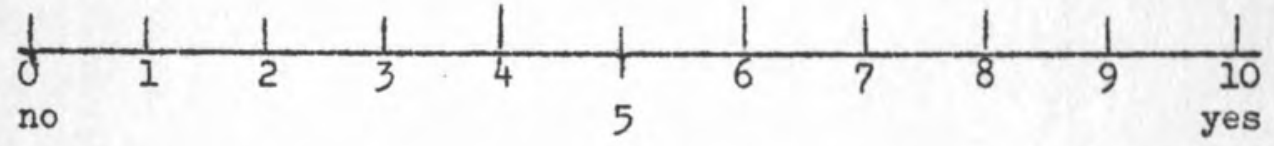

41. Does interviewee see faults others attribute to him as realistic?

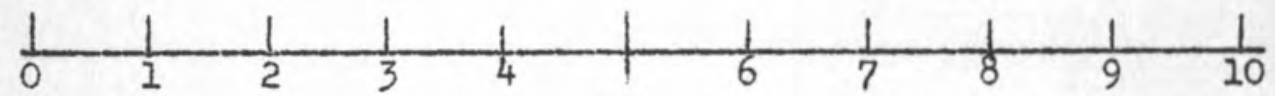

5

WHAT DELINGUENTS FEEL THEY HAVE TO OFFER.

42. Does interviewee feel inferior or superior to friends?

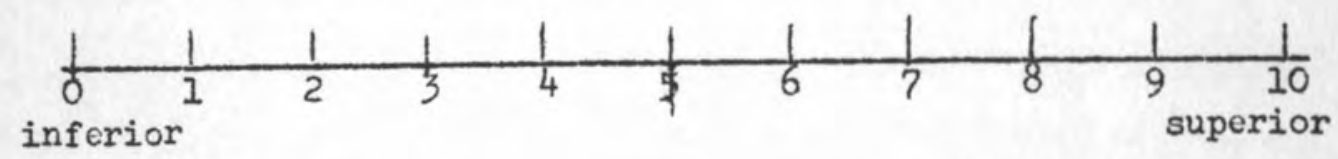

43. In what way does interviewee $f \in e l$ ingerior or superior (rank in order of importance to interviewee)
A.
Inferior superior
B.

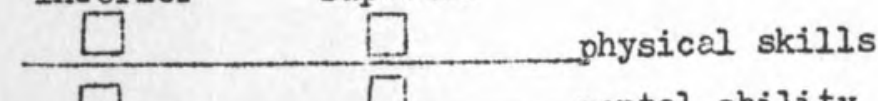
C.

$\square \quad \square \quad$ personality (specify traits
D.
$\frac{-\square}{\square}$ virtue
E.
F. $\square$ social skills
G. leadership other (specify 
43. Whot does interviewee feel other people like about him (rank in order of importance to interviewee)
A. 1. physical skills
B. $\square$ mental ability
C. $\square$ personality (specify traits
D. $[$ virtue (moral qualities)
B. $\square$ socian skills
F. $\square$ leadership
G. $\square$ other (specify

44. What does interviewee like about self (rank in order of importance to intervi(wee)
A. $\square$ physical appearance
B. $\square$ physical skills
C. $\square$ mental abilities
D. $\square$ personality (specify traits
E. $\square$ moral qualities
F. $\square$ social skills
G. $\square$ leadership
H. $\square$ other (specify

45. Interviewee feels he is good at ? (rank in order of importance to interviewee)
A. $\square$ physical skills
B. $\square$ having good personality
C. $\square$ moral qualities
D. Đsocial skills
E. Wleadership
F. $\square$ mental abilities
G. Jother (specify 
46. If nothing were standing in his way interviewee feels he could (rank in order of importance to interviewee)

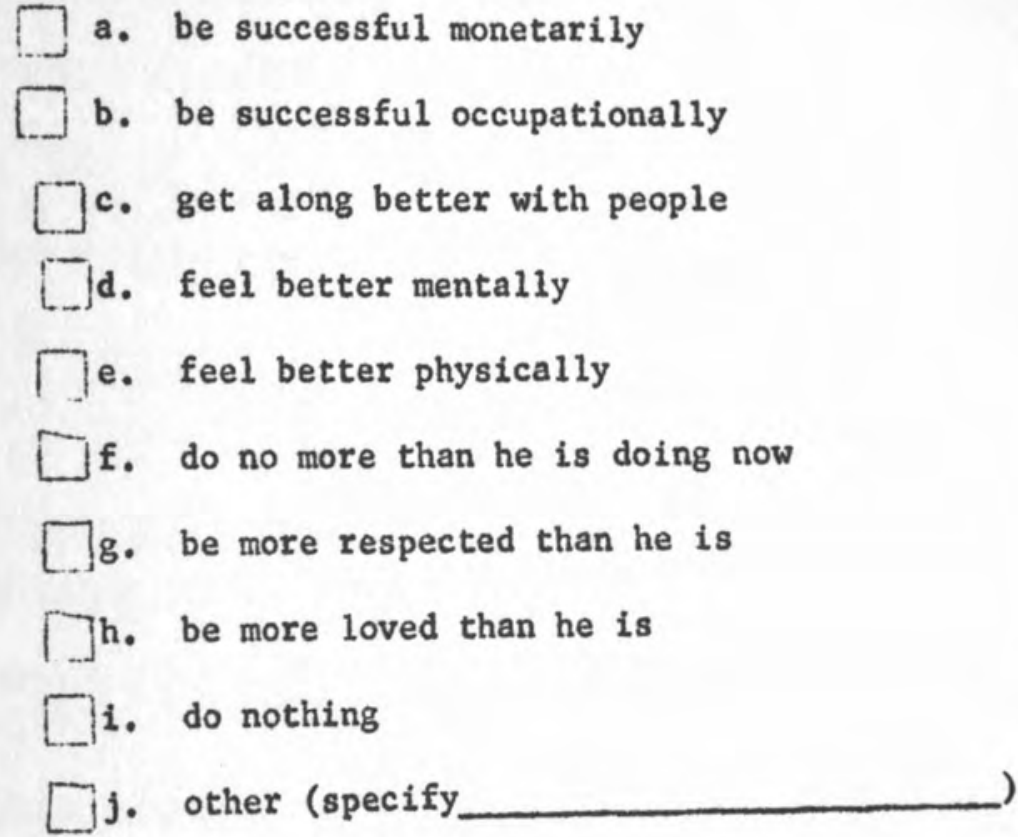

\section{WHAT DELINQUENTS SEE AS AN IDEAL SOCIETY}

47. To remake the world the interviewee would (rank in order of importance to interviewee)

[]a. destroy it first

[J b. change other people

G. change self (specify why

[jd. redistribute power

[e. redistribute wealth

$\square$ f. other (specify

Jg. nothing

Wh. interviewee unable to answer

48. Interviewee feels that to get along better with each other, people of all races and religions could: (rank in order of importance to interviewee)

$\square$ a. love one another

$\square$ b. have more respect for each others' rights

[c. give more to groups that support the "brotherhood of man"

$\square$ d. pressure the government to enforce the constitution or other legal methods 
Te. be more tolerant of one's neighbors, friends, and/or relatives

f. be forced to integrate across racial and religious lines

[]. other (specify.

[.]. no answer

49. Interviewee names the three greatest people in the United States as:

(1)

(2)

(3)

\section{INTERVIEWEE' \& IDEAS ON BEST THERAPY}

50. Interviewee feels he has been helped by: (rank in order of importance to interviewee)

Ta. Having some person listen to him talk

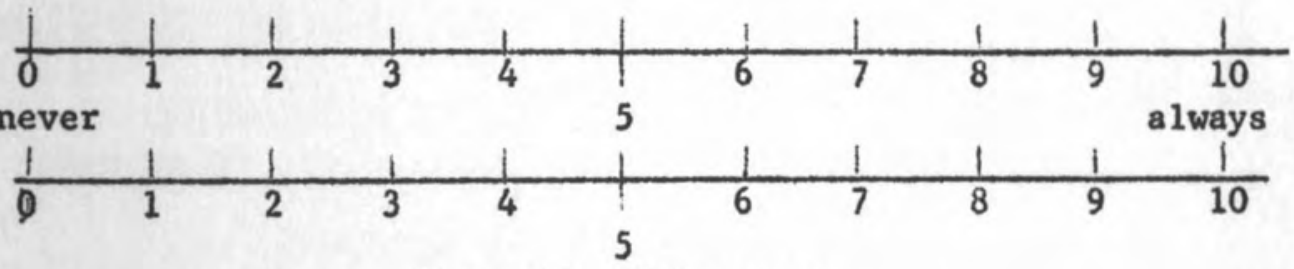

Intensity of Response

[ b. Having some person talk to him
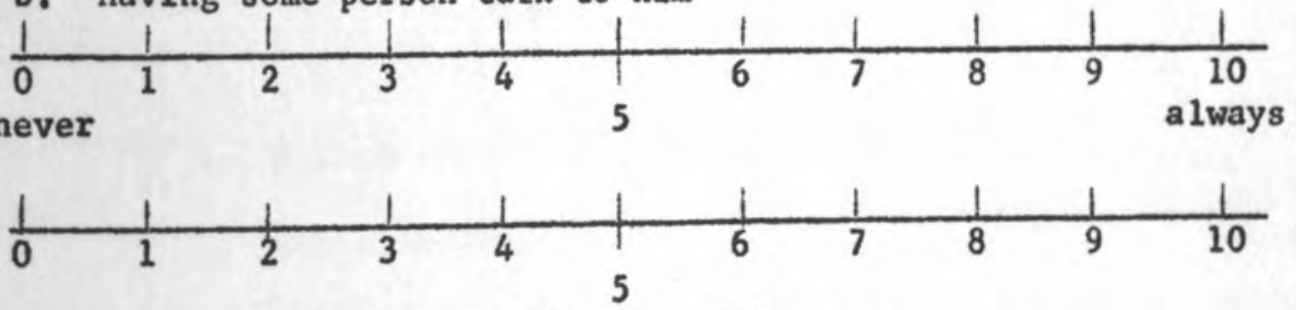

Intensity of Response

[]c. Having money made available to him
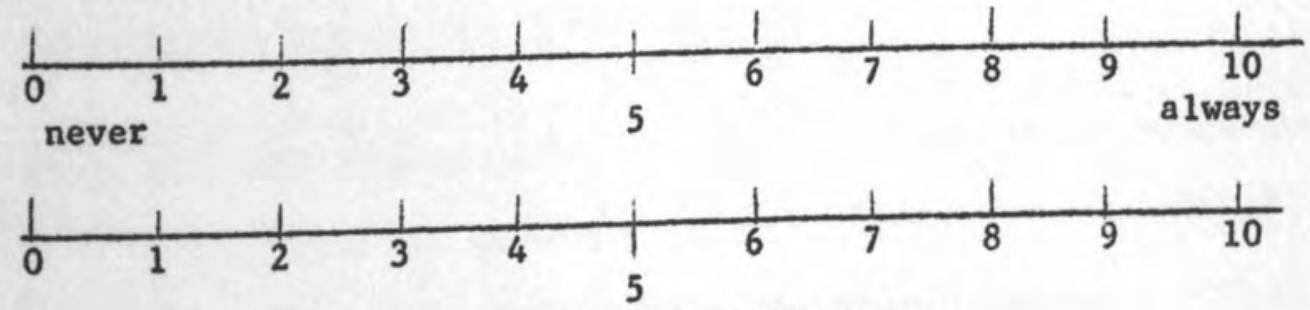

Intensity of Response 
$\square$ d. Having some adult engage in activity with him

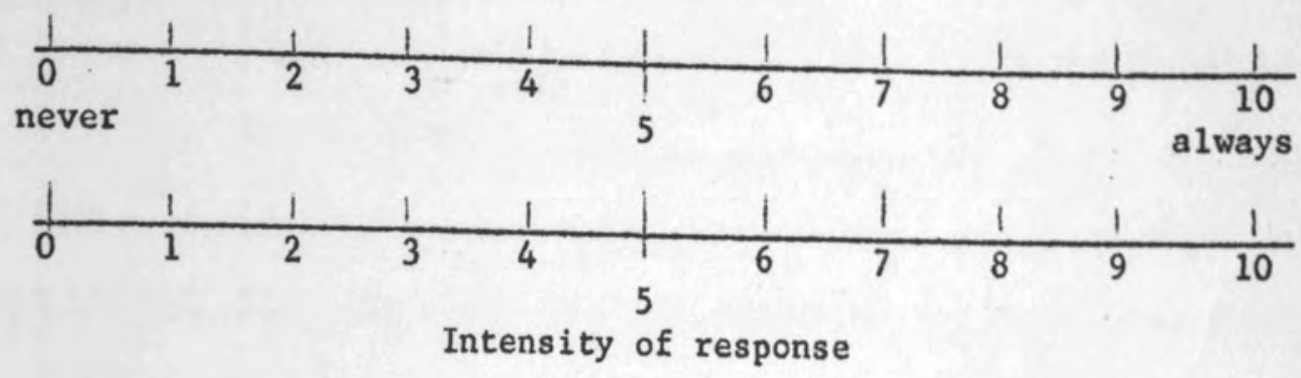

$\square$ e. Having peers engage in activity with him
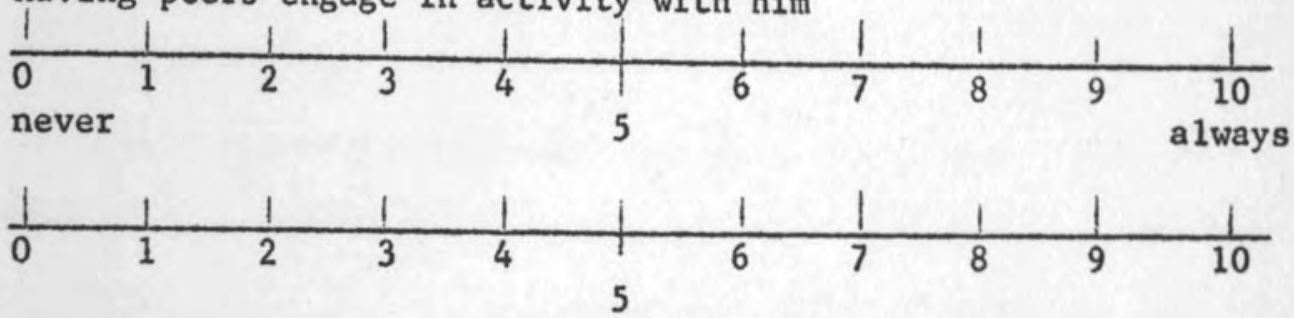

Intensity of Response

$\square$ f. Thinking things out for himself
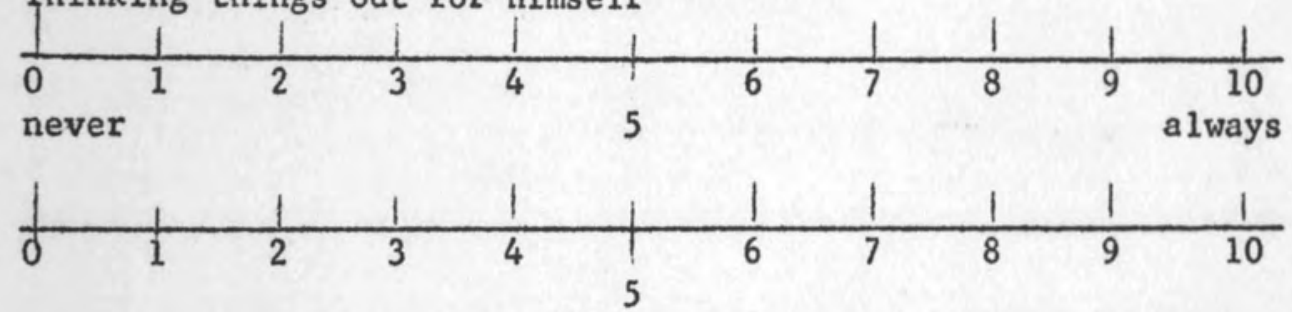

Intensity of Response

[g. Finding activities for himself
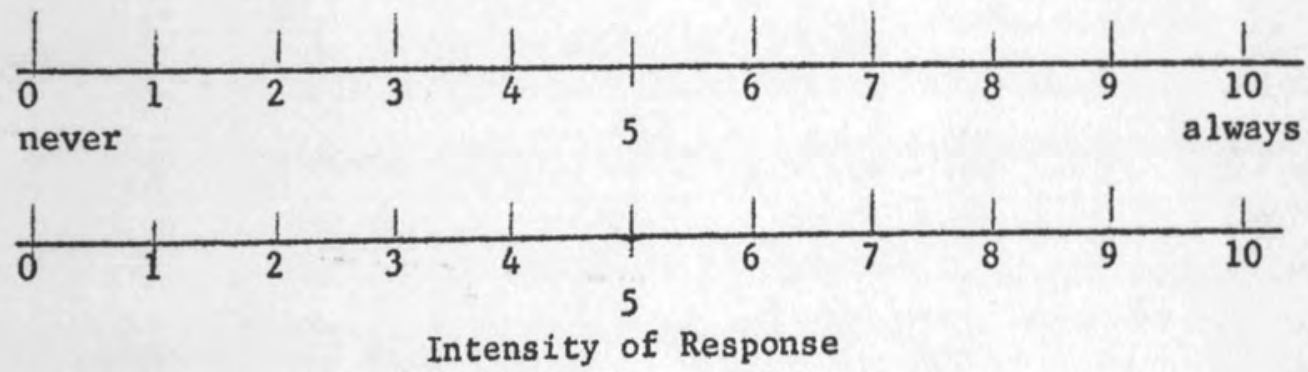

$\lceil$ h. Other (specify
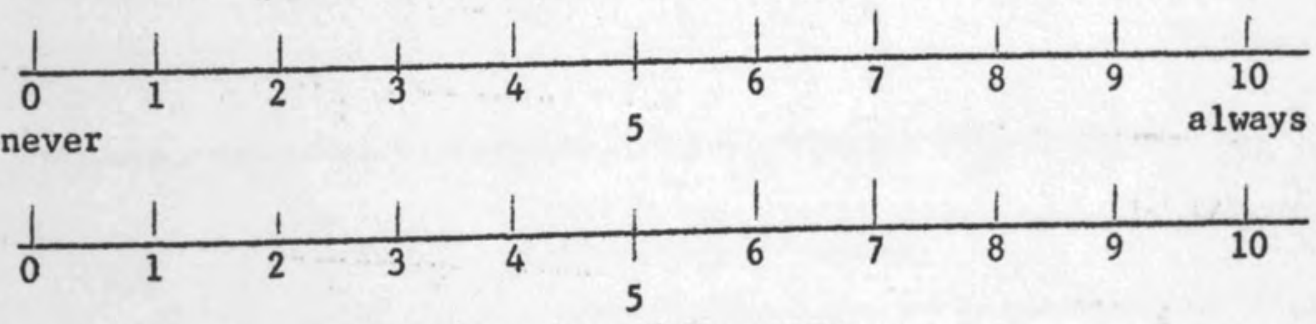

Intensity of Response 

51. Interviewee feels other boys his age have been helped by: (rank in order of
importance to interviewee)

[a. Having some person listen to him talk
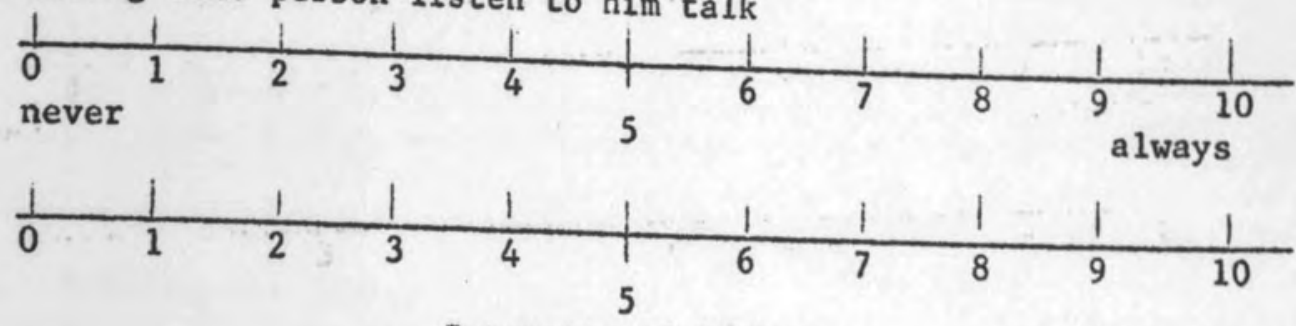

Intensity of Response

[b. Having some person talk to him
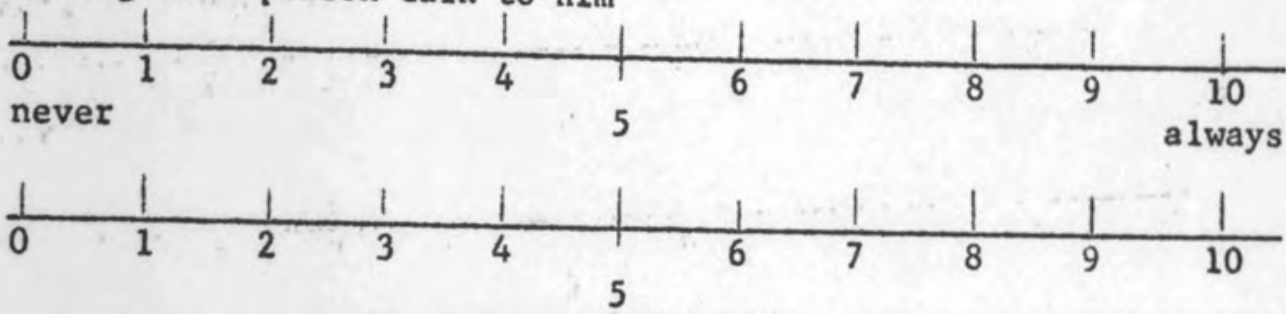

Intensity of Response

पc. Having money made available to him
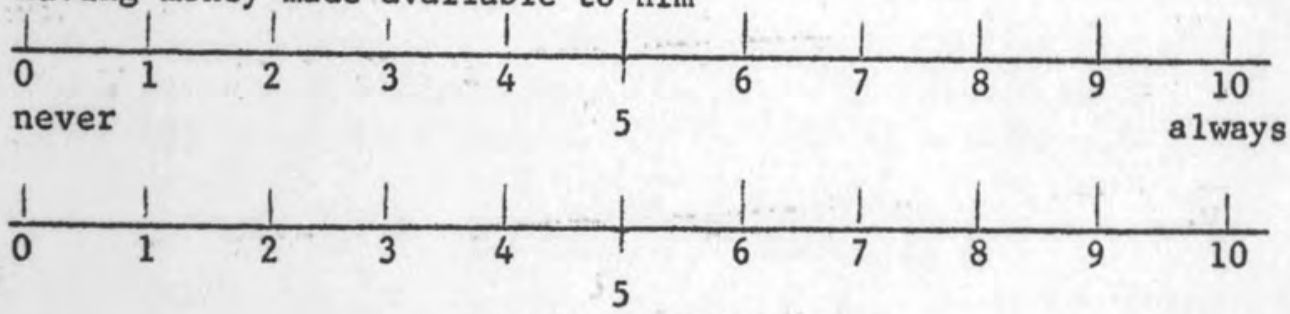

Intensity of Response

[. Having some adult engage in activity with him
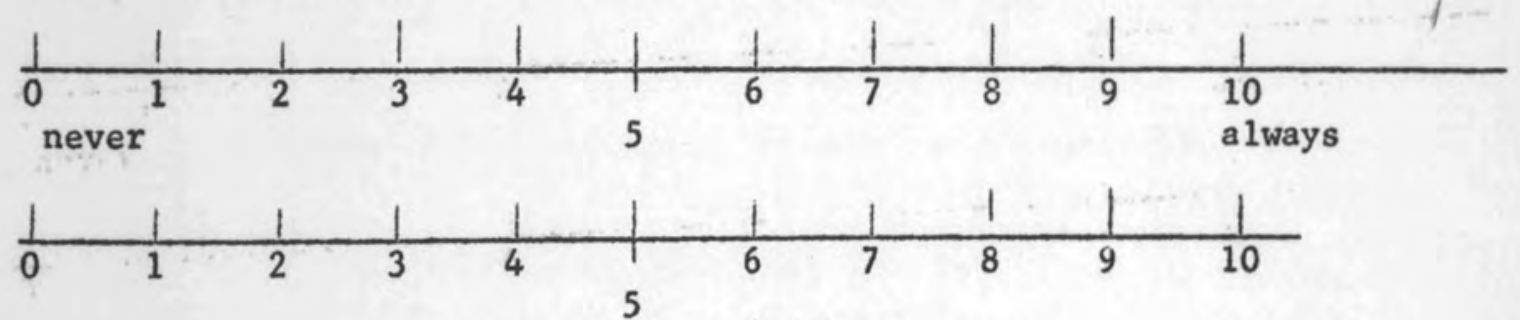

Intensity of Response

- Having peers engage in activity with him

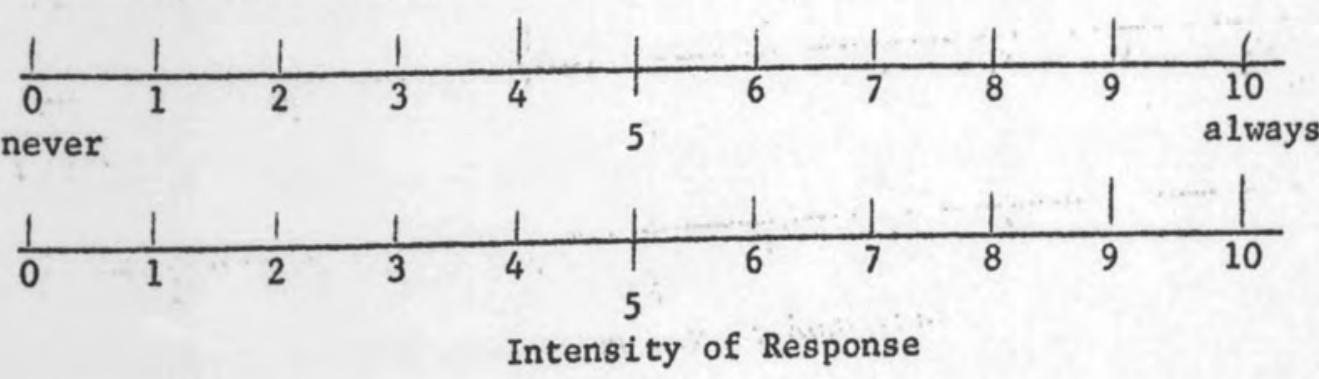


[f. Thinking things out for himself
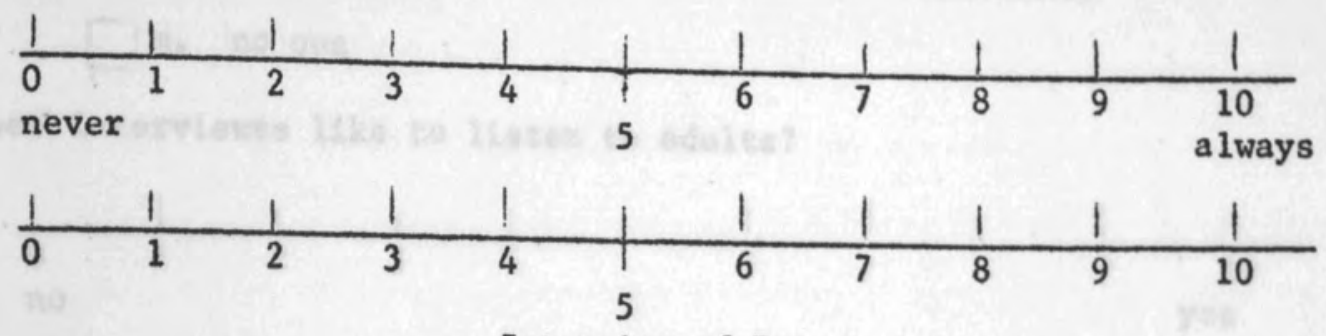

Intensity of Response

प... Finding activities for himself
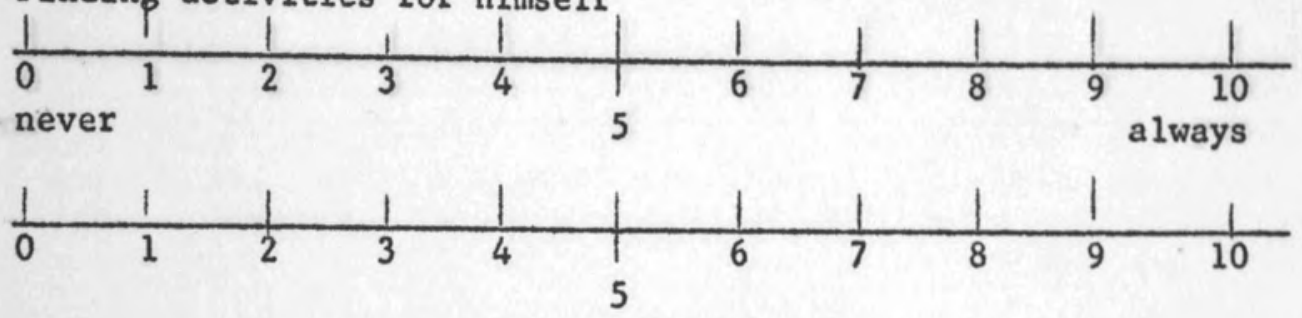

Intensity of Response

$\square^{\text {h. }}$ other (specify
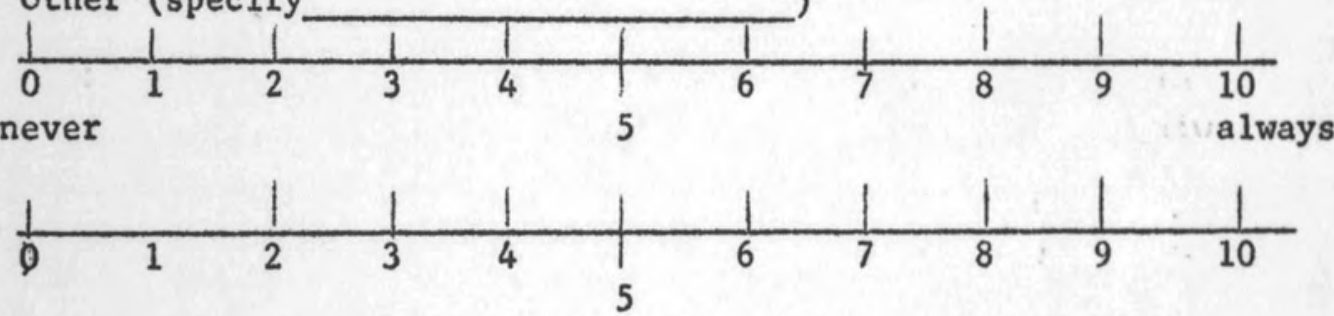

Intensity of Response

52. Since interviewee has been in trouble who does he think has helped him? (rank in order of importance to interviewee)

a. mother

b. father

$\square$ c. both parents

[.]d. peers

[]e. siblings

[]f. other relatives (specify

[g. judge

[.. h. counselors

$\square$ i. cottage parents

$\square$ j. teachers

$\square$ k. minister or priest 
1. other adults (specify)

[. m. no one

53. Does interviewee like to listen to adults?

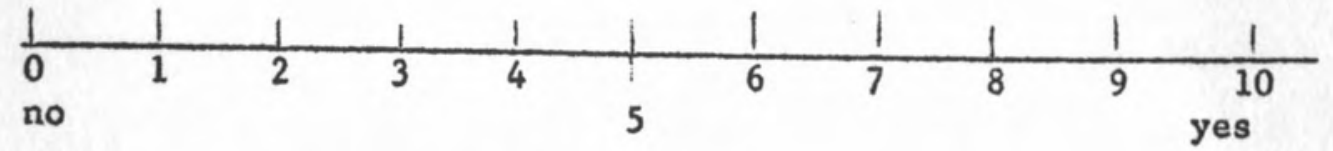

54. Do adults like to listen to interviewee?

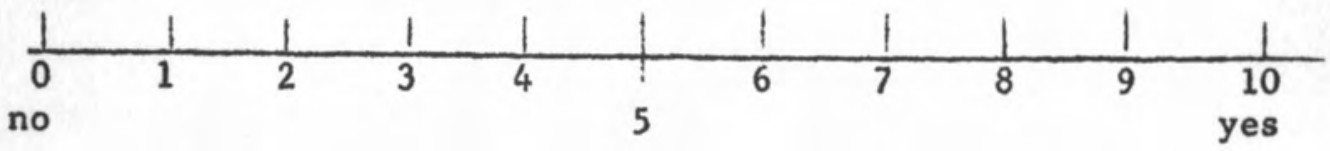


Question \#8

Section $1 / 2$

$\mathrm{H}_{\mathrm{oa}}$ : There is no slgmificant difference among the ratings of the observers with regard to the interviewees' acceptance and/or resentment of physical or corporal punishment.

$\mathrm{H}_{\mathrm{Oa}}$ : Not rejected。

$\mathrm{H}_{\mathrm{ob}}$ : ... being detained at home, school, or by court.

$\mathrm{H}_{\mathrm{ob}}$ : Not rejected.

$\mathrm{H}_{\mathrm{oc}}$ : - ohaving money or material goods withheld from them.

$\mathrm{H}_{\mathrm{oc}}$ : Not rejected。

$\mathrm{H}_{\mathrm{od}} \mathrm{w}^{2}$. ohaving privileges withheld from them。

Hod: Not rejected.

$\mathrm{H}_{\mathrm{Oe}}$ : There is no significant difference between the acceptance or rejection of types of punishment as ravied by the observers.

$\mathrm{H}_{\mathrm{oe}}$ : Rejected。

Question 1188

Section $\mathbb{2}$ :

$\mathrm{H}_{\mathrm{og}}$ : There is no significant difference among the ratings of the observers with regard to the interviewees' thinking, in terms of fair and unfair, with reference to physical or corporal punishment.

$\mathrm{H}_{\mathrm{OQ}}$ : Not rejected。

$\mathrm{H}_{\mathrm{ob}}$ : . obeing detained at home, school, or court。

$\mathrm{H}_{\mathrm{ob}}$ : Not rejected。

$\mathrm{H}_{\mathrm{oc}}$ : There is no significant difference among the categories of boys with regard to their thinking about the faimess or unfairness of physical or corporal punishment. 
Hoc: Not rejected。

Hod: - owithholding money or material goods.

$\mathrm{H}_{\text {od: }}$ Not rejected.

$\mathrm{H}_{\infty e}$ : There is no significant difference among types of punishment in regard to observers rating of fair versus unfair.

$\mathrm{H}_{\mathrm{Oe}}$ : Rejected.

Question \#8

Section \#3:

$\mathrm{H}_{\mathrm{Oa}}$ : There is no significant difference among types of punishment in regard to observer ratings of conformity versus continuance of prohibited activity.

$\mathrm{H}_{\mathrm{oa}}$ : Rejected.

Question $\# 10$

$\mathrm{H}_{\mathrm{OQ}}$ : There is no signfficant difference among the ratings of the observers with regard to their estimation of the degree of identifica tion of the boys with their peers.

$\mathrm{H}_{\mathrm{Oa}}$ : Not rejected.

$\mathrm{H}_{\mathrm{ob}}$ : There is no significant difference among the categories of boys with regard to the degree of identification with their peers.

$\mathrm{H}_{\mathrm{ob}}$ : Not rejected.

$H_{o c}$ : There is no significant difference between the variance of the observers' scores and the variance of the boys' scores.

$\mathrm{H}_{\mathrm{oc}}$ : Rejected.

$\mathrm{H}_{\mathrm{od}}$ : There is no significant difference between the scores given the probationer and scores given parolees regarding their degree of Identification with their poors. 
Hod: Rejected.

\section{of what are delinquents fearful?}

Question \#16

$\mathrm{H}_{\mathrm{Oa}}$ : There is no significant difference among the categories of boys with regard to what they see as their most frightening experience in terms of natural phenomena.

$\mathrm{H}_{\mathrm{oa}}$ : Rejected。

$\mathrm{H}_{\mathrm{ob}}: \ldots$ man-made environment.

$\mathrm{H}_{\mathrm{ob}}$ : Not rejected.

$\mathrm{H}_{\mathrm{oc}}: \ldots$ own bodily damage.

$\mathrm{H}_{\mathrm{OC}}$ : Not rejected。

$\mathrm{H}_{\text {od }}:$ oown uncontrolled feelings。

Hod: Not rejected.

$\mathrm{H}_{\mathrm{oe}}$ : . . ouncontrolled feelings of others.

$\mathrm{H}_{\mathrm{oe}}$ : Not rejected.

$\mathrm{H}_{\mathrm{of}}$ : There is no significant difference in types of frightening experiences as rated by the observers.

$\mathrm{H}_{\text {of }}$ : Rejected。

$\mathrm{H}_{\mathrm{Og}}$ : There is no significant difference in observer ratings of what boys feared in terms of human relationships versus the inanimate world and feelings of self.

$\mathrm{H}_{\text {og }}$ : Rejected.

Question \#18

$\mathrm{H}_{\mathrm{oa}}$ : There is no significant difference among the ratings of the observers with regard to their estimations of the importance of the 
possession of money to the interviewees.

$\mathrm{H}_{\mathrm{oa}}$ : Not rejected.

$\mathrm{H}_{\mathrm{ob}}$ : There is no significant difference among the categories of boys with regard to their attitudes toward the importance of the possession of money.

$\mathrm{H}_{\mathrm{ob}}$ : Not rejected.

Question \#19

$\mathrm{H}_{\mathrm{Oa}}$ : There is no significant difference among the ratings of the observers with regard to their estimations of how common the interviewees think loneliness is.

$\mathrm{H}_{\mathrm{Oa}}:$ Not rejected。

$\mathrm{H}_{\mathrm{ob}}$ : There is no significant difference among the categories of boys with regard to how common they think loneliness is.

$\mathrm{H}_{\mathrm{ob}}$ : Not rejected.

What are their aspirations for the future?

Question \#2I

$\mathrm{H}_{\mathrm{Oa}}$ : There is no significant difference among the ratings of the observers with regard to the boys' future self-image in terms of being rich or poor.

$\mathrm{H}_{\mathrm{Oa}}$ : Not rejected.

$\mathrm{H}_{\mathrm{ob}}$ : - successful or unsuccessful.

$\mathrm{H}_{\mathrm{Ob}}$ : Not rejected.

$\mathrm{H}_{\mathrm{oc}}$ : . . ointelligent or dull.

$\mathrm{H}_{\mathrm{oc}}$ : Not rejected. 


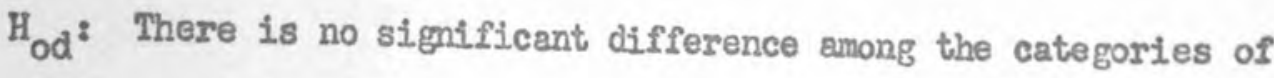
boys with regard to their future self-image in terms of being rich or poor。

$\mathrm{H}_{\mathrm{od}}$ : Not rejected.

He : - esuccessful or unsuccessful.

$\mathrm{H}_{\mathrm{Oe}}$ : Not rejected.

$\mathrm{H}_{\mathrm{of}}$ : .. intelligent or dull.

Hof: Not rejected.

Hog: There is no significant difference among the ratings of the observers as to how they think the boys see their future persanality traits.

Hog: Not rejected.

\section{Question \#2I A}

$\mathrm{H}_{\mathrm{Oa}}$ : There is no significant difference among the categories of boys with regard to theis coneeptions of their future family roles.

$\mathrm{H}_{\mathrm{Os}}$ : Not rejected.

$\mathrm{H}_{\mathrm{Ob}}$ : .. future military service.

$\mathrm{H}_{\mathrm{ob}}$ Not rejected.

Hoc: There is no signtficant difference among the ratings of the observers as to how they see the boys defining their future roles.

$\mathrm{H}_{\mathrm{oc}}$ : Rejected.

\section{Question \#25}

$\mathrm{H}$ oa: There is no significant difference among the categories of boys as to how they see themselves identifying with unrelated adult figures. 
$\mathrm{H}_{\mathrm{Oa}}^{2}$ Not rejected.

$\mathrm{H}_{\mathrm{ob}}{ }^{\mathrm{t}}$ There is no significant difference between whether the boys identify in future roles with parents, contemporaries (peers), or other adults.

$\mathrm{H}_{\mathrm{ob}}$ : Rejected.

What do delinquents feel they have to overcome?

Question \#33

$\mathrm{H}_{\mathrm{Oa}}$ : There is no significant difference among the categories of boys with regard to what bothers them about themselves in terms of physical prowess。

$\mathrm{H}_{\mathrm{oz}}$ : Rejected.

$\mathrm{H}_{\mathrm{Ob}}$ : .. olacking self-confidence 。

$\mathrm{H}_{\mathrm{Ob}}$ ? Not rejected。

$\mathrm{H}_{\mathrm{oc}}{ }^{2}$.. olacking physical resources。

$\mathrm{H}_{\mathrm{OC}}$ : Not rejected。

$\mathrm{B}_{\mathrm{od}}$ : There is no significant difference among the ratings of the observers as to what traits they see as bothering the boys about themselves.

$\mathrm{H}_{\text {od }}$ : Rejected。

\section{Question \#35}

$\mathrm{H}_{\mathrm{OS}}$ : There is no significant difference among the categories of boys with regard to what they think bothers other adolescents about themselves, in terms of selfoworth.

$\mathrm{H}_{\mathrm{Oa}}$ : Not rejected.

$\mathrm{H}_{\mathrm{ob}}$ : There is no significant difference in the ratings of the observers as to the traits the interviewees think bothers other 
observers as to the trafts the interviewees think bothers other adolescents about themselves.

$\mathrm{H}_{\mathrm{ob}}$ : Rejected.

What do delinquents feel they have to offer?

Question $\# 42$

$\mathrm{H}_{\mathrm{os}}$ There is no signtficant difference among the observers as to whether or not they think the interviewees feel irferior or superlox to their friends.

Hos Rejected.

$\mathrm{H}_{\mathrm{ob}}$ : There is no significant difference among the categories of boys as to whether or not they feel inferion or superior to their friends.

$\mathrm{H}_{\mathrm{ob}}$ : Rejected.

$H_{o c}$ : There is no signiflcant difference between the leoLaren interviewees and the probation interviewees as to whether or not they feel inferior or superior to their friends.

$\mathrm{H}_{\mathrm{Oc}}$ : Rejected.

$\mathrm{H}_{\text {od: }}$ There is no significant difference between probation inter. viewees and parole interviewees as to whether or not they feel in ferior or superior to their friends.

$\mathrm{H}_{\text {od }}$ Not rejected.

$\mathrm{H}_{o e^{2}}$. There is no significant difference between the MacLaren interviewees and the parole interviewees as to whether or not they feel inferior or superior to their friends.

$\mathrm{H}_{\mathrm{OQ}}$ : Rejected. 
Question $\$ 433$ A

$\mathrm{H}_{\mathrm{Oa}}$ : There is no significant difference among the categories of boys with regard to what they think other people like about them in terms of their physical skills.

$\mathrm{H}_{\mathrm{Oa}}{ }^{2}$ Rejected.

$\mathrm{H}_{\mathrm{ob}}$ : .. their mental ability.

$\mathrm{H}_{\mathrm{ob}} 2$ Not rejected.

$\mathrm{H}_{\mathrm{oc}}$ : ... their personality。

$\mathrm{H}_{\mathrm{oc}}$ : Not rejected.

$\mathrm{H}_{\mathrm{od}}$ : There is no significant difference among the ratings of the observers as to what traits the interviewses feel other people liked about them.

$\mathrm{H}_{\text {od }}^{2}$ Rejectod.

Question 部4

$\mathrm{H}_{\mathrm{OQ}}$. There is no significant difference among the categories of boys with regard to what they like about themselves in terms of their physical appearance.

$\mathrm{H}_{\mathrm{OQ}}$ : Rejected.

$\mathrm{H}_{\mathrm{ob}}$ : ... ophysical skills.

$\mathrm{H}_{\mathrm{ob}}:$ Rejectsd.

$\mathrm{H}_{\mathrm{OC}}^{2}$... mental abilities.

$\mathrm{H}_{\mathrm{OC}}$ ? Not rejected.

$\mathrm{H}_{\mathrm{od}}$ : There is no significant difference among the ratings of the observers as to what traits the boys like about themselves.

Hod: Rejected. 
Question \#45

$\mathrm{H}_{\mathrm{oa}}$ ? There is no significant difference among the categories of boys as to whether they feel they are good at physical skills.

$\mathrm{H}_{\mathrm{oQ}}$ : Not rejected。

$\mathrm{H}_{\mathrm{ob}}:$.. emental abilities.

$\mathrm{H}_{\mathrm{ob}}$ : Rejected。

$\mathrm{H}_{\mathrm{oc}}$ : There is no significant difference among the ratings of the observers as to what traits the boys feel they are good at.

$\mathrm{H}_{\mathrm{oc}}$ : Rajected.

What do delinquents see as an ideal society?

Question 能?

$\mathrm{H}_{\mathrm{Oa}}$ : There is no significant difference among the categories of boys as to whether they would redistribute power in our society.

$\mathrm{H}_{\mathrm{OQ}}$ : Rajected.

$\mathrm{H}_{\mathrm{ob}}$. . oredistribute wealth in our society。

$\mathrm{H}_{\mathrm{ob}^{2}}$ Rejectad.

$\mathrm{H}_{\mathrm{oc}}$ : There is no significant difference in the ratings by the observers as to what the interviewees would do to remake the world.

$\mathrm{H}_{\mathrm{oc}}$ : Rejected.

that do delinguents think is the best therapy?

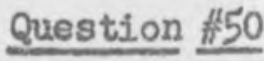

$\mathrm{H}_{\mathrm{Oa}}$ : There is no significant difference among the ratings of the observers with regard to whether the interviewees feel they have been helped by having some person listen to them talk. 
$\mathrm{H}_{\mathrm{oa}}:$ Not rejected.

$\mathrm{H}_{\mathrm{ob}}$ - - osome person ta.lk to them。

$\mathrm{H}_{\mathrm{ob}}$ : Rejected。

$\mathrm{H}_{\mathrm{oc}}$ : There is no significant difference among the categories of boys regarding whether they feel they have been holped by having some person listen to them talk.

$\mathrm{H}_{\mathrm{oc}}$ : Not rejectsd。

$\mathrm{H}^{2}$ - osome person talk to them。

$\mathrm{H}_{\text {od }}$. Not rejected.

$\mathrm{H}_{\mathrm{oe}}$ : - osome acult engage in activity with them。

$\mathrm{H}_{\mathrm{oe}}$ : Rejected。

$\mathrm{H}_{\text {of: }}$ - opeers engage in activities with them。

$\mathrm{H}_{\mathrm{of}}^{2}$ Not rejected.

$\mathrm{H}_{\mathrm{Og}}$. . ofinding activities for themselves.

$\mathrm{H}_{\mathrm{Og}}:$ Not rejected.

$\mathrm{H}_{\mathrm{oh}}$ : There is no significant difference in the ratings of the observers as to how the interviewees feel they have been helped。

$\mathrm{H}_{\mathrm{Oh}}$ : Rejected。

Question \#52

$\mathrm{H}_{\mathrm{OQ}}$ : There is no significant difference among the categories of boys regarding, whether they think other relatives have helped them since they have been in trouble.

$\mathrm{H}_{\mathrm{OQ}}$ : Rejected。

$\mathrm{H}_{\mathrm{ob}}:$. . the judge has helped them since they have been In trouble. 
$\mathrm{H}_{\mathrm{Ob}}:$ Rejected.

$H_{0 c}:$ ocounselors have helped them since they have been in trouble.

$\mathrm{H}_{\mathrm{oc}}$ : Rejected.

$\mathrm{H}_{\text {od: }}$ - ocottage parents have helped them since they have been in trouble.

Hod: Rejected.

$\mathrm{H}_{\mathrm{Oe}}$... oteachers have helped them since they have boen in trouble.

$\mathrm{H}_{\mathrm{OQ}} \mathrm{Q}^{\mathrm{R}}$ Rejected.

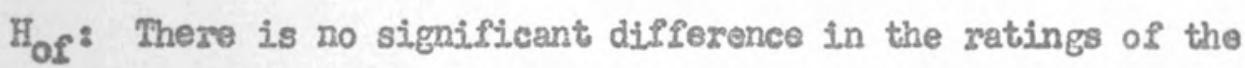
observers as to who the interviewes feel have helped them since they have boen in trouble.

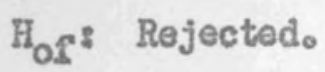


Hypothesis

Question \#3

$\mathrm{H}_{\mathrm{Oa}}$

$\mathrm{H}_{\mathrm{Ob}}$

$\mathrm{H}_{\mathrm{oc}}$

HI

Question \#6
$\mathrm{H}_{\mathrm{OQ}}$
$\mathrm{H}_{\mathrm{ob}}$
Chi-square
Chi-square

Question \#8

Section 1
II $\mathrm{oa}$

$\mathrm{H}_{\mathrm{ob}}$

$\mathrm{H}_{\mathrm{oc}}$

$\mathrm{H}_{\mathrm{Od}}$

$\mathrm{H}_{\mathrm{Oe}}$

Section 2

Hoa

$\mathrm{H}_{\mathrm{Ob}}$

Hod

II

$\mathrm{H}_{\mathrm{Oe}}$
Student's \&

Chi-square

Chi-square

Chi -squars
Ratio

$-1.55$

1.39

3.87

16.31

\section{Probabi.lity*}

$P>0.10$

P>.05

P>.05

$\mathrm{P}<.005$
509.1

$\mathrm{p}>0.05$

27.8

$\mathrm{P}<.005$

$\begin{array}{rl}.6423 & P>0.10 \\ .79 & P>0.10 \\ 2.41 & P>0.05 \\ 1.27 & P>0.05 \\ 47.29 & P<.005\end{array}$

.84

P>.10

.0399

$P>.50$

Studisn's t

ChI-square

Chissquare

Chi-square

$$
.05
$$

.0526

94.61
$P>0.05$

$P>.05$

$P<.005$ 
Hypothesis

Test

Section 3

$$
\mathrm{H}_{\mathrm{Oa}}
$$

Chi-square

Question 10

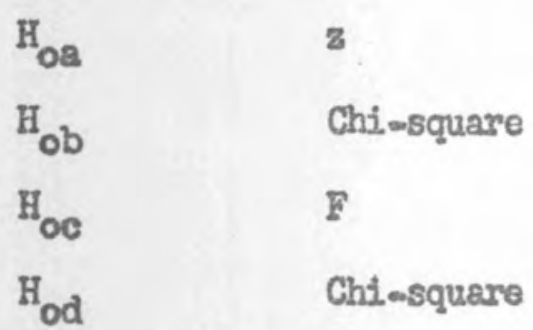

Question \$16

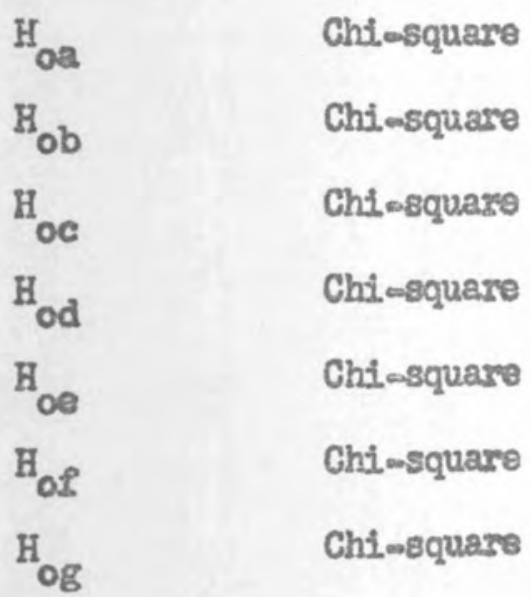

Question \#18

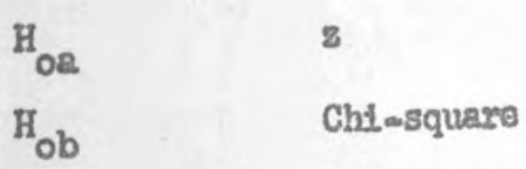

Question \#19

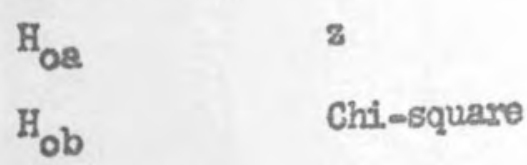

Question \#2I

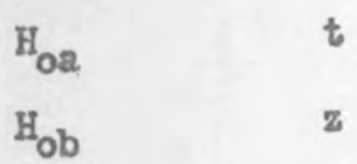

Ratio

Probabil1ty*

36.98

$\mathrm{P}<.005$

2.297

P $>.02<.01$

1.91

P $>.05$

2.3316

$\mathrm{P}<.05>0.01$

9.70

$\mathrm{p}<.01>.001$

9.12

$\mathrm{P}<.025>0.01$

1.9

P>.05

5.36

P> 0.05

5.36

P) .05

4.42

p>.05

295.25

$\mathrm{P}<.005$

49.92

$\mathrm{P}<.005$

.81

P>. 10

2.88

P>.05

1.33

P $>.10$

.88

P>.05

1.4

$\mathrm{P}<.25>.10$

.80

P>. 20 
Hypothesis

Hoc

Hod

$\mathrm{H}_{\text {oe }}$

Hor

$\mathrm{H}_{\mathrm{Og}}$

Question \#21 A

$\begin{array}{ll}\mathrm{H}_{\mathrm{os}} & \text { Chiesquare } \\ \mathrm{H}_{\mathrm{Ob}} & \text { Chimsquare } \\ \mathrm{H}_{\mathrm{Oc}} & \text { Chissquare }\end{array}$

Question \#25

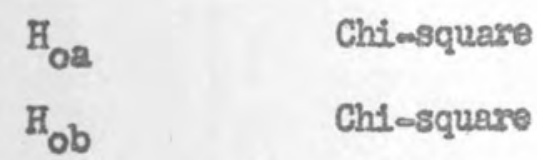

Question \#33

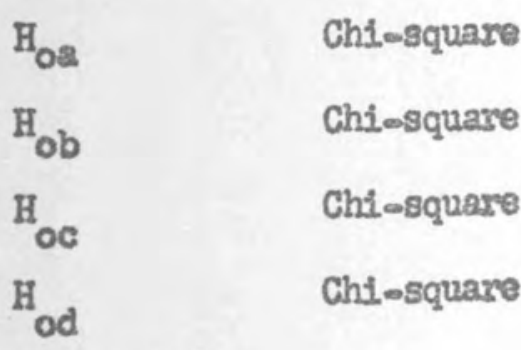

Question \#35

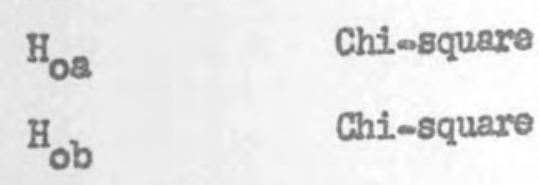

Question \#42

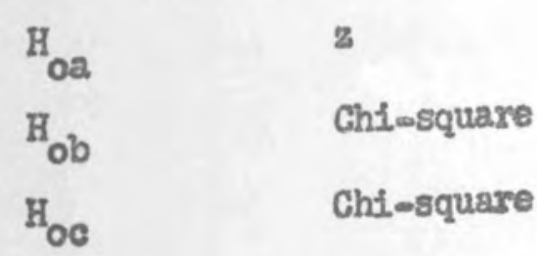

Ratio

.19

.00

.25

1.48

8.19

2.10

P> .05

2.68

P > 05

40.42

$\mathrm{P}<{ }_{0} 005$

P> .05

P> .05

P) 0.05

P>.50

$>1.00$

Probability*

4.37

$p>0.05$

7.32

$P<.05>.025$

9.33

$\mathrm{P}<{ }_{0} 01>{ }_{0} 005$

2.16

P > 005

3.35

P > $>05$

$2,216.7$

$P<.005$

3.65

$P>005$

103.73

$P<.005$

2.02

$p>.04<.05$

6.34

$\mathrm{P}<.05>.025$

4.12

$\mathrm{P}<.05>.025$ 
Hypothesis

$\mathrm{H}_{\text {od }}$

$\mathrm{H}_{\mathrm{Oe}}$

Chi-square

Chi-square

Question \#43 A

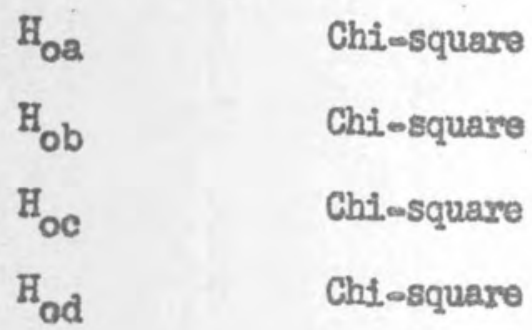

Question 故4

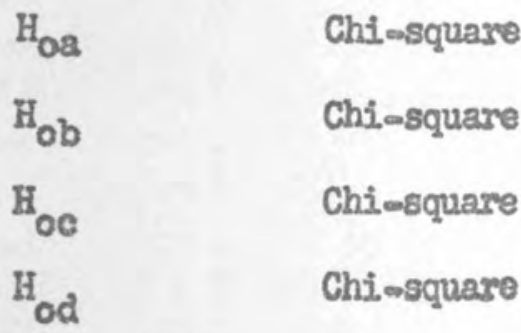

Question \#45

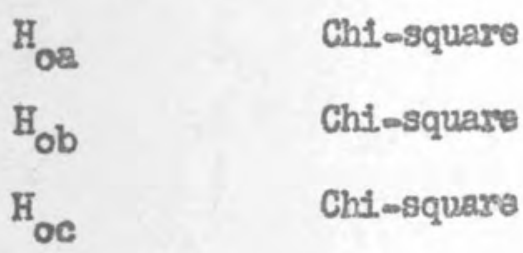

Question flu?

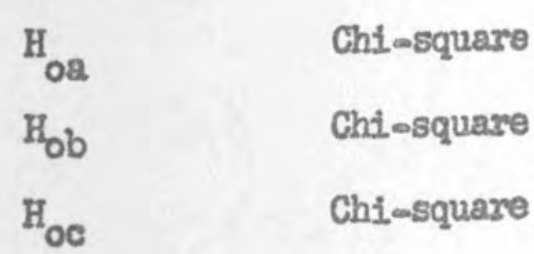

Question \#50

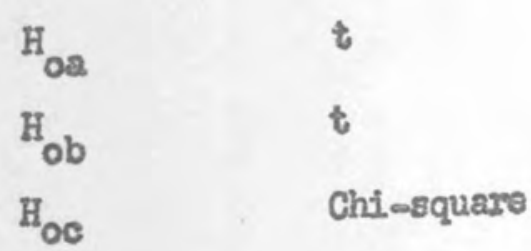

Ratio

42

13.24

Probabilitty*

$P>0.05$.

$P<.005$

7.26

4.86

4.5

61.1

28.88

13.17

3.57

59.84

2.73

8.42

49.48

$P<.005$

$\mathrm{P}<.005$

P>.05

$\mathrm{P}<.005$

P >.05

P >.05

$\mathrm{P}<.005$

$\mathrm{P}<.025>.01$

P>.05

$\mathrm{P}<{ }_{.025}>{ }_{.01}$

$\mathrm{p}<.005$

12.15

10.38

$P<.005$

$\mathrm{P}<.005$

163.84

$\mathrm{P}<.005$

.32

$P>.50$

4.292

$\mathrm{P}<.005$

.6105

P $>.05$ 


\begin{tabular}{|c|c|c|c|}
\hline Eypothesis & Test & Ratio & Probsbilitut* \\
\hline $\mathrm{H}_{\mathrm{Od}}$ & Chi-squase & 1.325 & $P>.05$ \\
\hline $\mathrm{H}_{\mathrm{OO}}$ & Chi-squase & 6.25 & $.05>.025$ \\
\hline $\mathrm{H}_{\text {of }}$ & Chi-square & 2.94 & $P>.05$ \\
\hline $\mathrm{H}_{\mathrm{Og}}$ & Chi-square & 3.74 & $P>0.05$ \\
\hline $\mathrm{H}_{\mathrm{oh}}$ & Chi-square & 48.54 & .005 \\
\hline
\end{tabular}

Question 452

$\begin{array}{llll}\mathrm{H}_{\mathrm{Oa}} & \text { Chi-square } & 11.12 & \mathrm{P}<.005 \\ \mathrm{H}_{\mathrm{Ob}} & \text { Chissquare } & 7.62 & \mathrm{P}<.025>.01 \\ \mathrm{H}_{\mathrm{oc}} & \text { Chi-square } & 7.99 & \mathrm{P}<.025>.01 \\ \mathrm{H}_{\text {od }} & \text { Chi-square } & 19.50 & \mathrm{P}<.005 \\ \mathrm{H}_{\mathrm{O}} & \text { Chi-square } & 15.18 & \mathrm{P}<.005 \\ \mathrm{H}_{\mathrm{O}} & \text { Chi-square } & 114.74 & \mathrm{P}<.005\end{array}$

*Probabilitity was obtained Irozn statistical tables in Paul B. Hall, Elementary Statistics, John Wiley and Sons, Inc., New York, 1960, pp. 240-245 